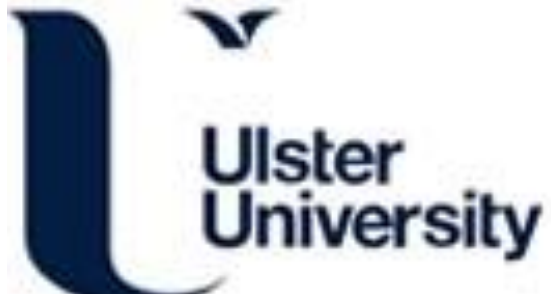

\section{Targeting eosinophils in respiratory diseases: Biological axis, emerging therapeutics and treatment modalities}

Lee, L., Hew, G. S. Y., Mehta, M., Shukla, S. D., Satija, S., Khurana, N., Anand, K., Dureja, H., Singh, S. K., Mishra, V., Singh, P. K., Gulati, M., Prasher, P., Aljabali, A. A. A., Tambuwala, M. M., Thangavelu, L., Panneerselvam, J., Gupta, G., Zacconi, F. C., ... Dua, K. (2021). Targeting eosinophils in respiratory diseases: Biological axis, emerging therapeutics and treatment modalities. Life Sciences, 267, [118973]. https://doi.org/10.1016/j.Ifs.2020.118973

Link to publication record in Ulster University Research Portal

\section{Published in:}

Life Sciences

Publication Status:

Published (in print/issue): 15/02/2021

DOI:

10.1016/j.Ifs.2020.118973

\section{Document Version}

Author Accepted version

\section{General rights}

Copyright for the publications made accessible via Ulster University's Research Portal is retained by the author(s) and / or other copyright owners and it is a condition of accessing these publications that users recognise and abide by the legal requirements associated with these rights.

\section{Take down policy}

The Research Portal is Ulster University's institutional repository that provides access to Ulster's research outputs. Every effort has been made to ensure that content in the Research Portal does not infringe any person's rights, or applicable UK laws. If you discover content in the Research Portal that you believe breaches copyright or violates any law, please contact pure-support@ulster.ac.uk. 


\section{Journal Pre-proof}

Targeting eosinophils in respiratory diseases: Biological axis, emerging therapeutics and treatment modalities

Li-Yen Lee, Geena Suet Yin Hew, Meenu Mehta, Shakti D. Shukla, Saurabh Satija, Navneet Khurana, Krishnan Anand, Harish Dureja, Sachin Kumar Singh, Vijay Mishra, Pankaj Kumar Singh, Monica Gulati, Parteek Prasher, Alaa A.A. Aljabali, Murtaza M. Tambuwala, Lakshmi Thangavelu, Jithendra

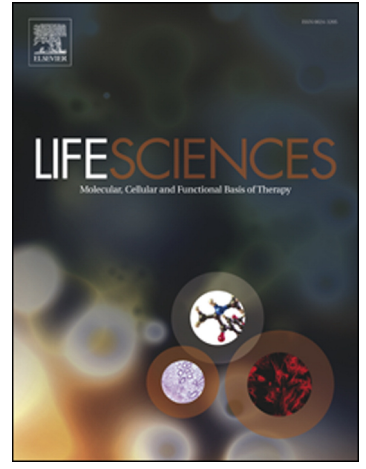
Panneerselvam, Gaurav Gupta, Flavia C. Zacconi, Madhur Shastri, Niraj Kumar Jha, Dikaia Xenaki, Ronan MacLoughlin, Brian G. Oliver, Dinesh Kumar Chellappan, Kamal Dua

PII: S0024-3205(20)31733-1

DOI: $\quad$ https://doi.org/10.1016/j.lfs.2020.118973

Reference: $\quad$ LFS 118973

To appear in: $\quad$ Life Sciences

Received date: $\quad 2$ October 2020

Revised date: $\quad 22$ December 2020

Accepted date: $\quad 23$ December 2020

Please cite this article as: L.-Y. Lee, G.S.Y. Hew, M. Mehta, et al., Targeting eosinophils in respiratory diseases: Biological axis, emerging therapeutics and treatment modalities, Life Sciences (2018), https://doi.org/10.1016/j.1fs.2020.118973

This is a PDF file of an article that has undergone enhancements after acceptance, such as the addition of a cover page and metadata, and formatting for readability, but it is not yet the definitive version of record. This version will undergo additional copyediting, typesetting and review before it is published in its final form, but we are providing this version to give early visibility of the article. Please note that, during the production process, errors may be discovered which could affect the content, and all legal disclaimers that apply to the journal pertain. 
(C) 2018 Published by Elsevier. 
Targeting eosinophils in respiratory diseases: biological axis, emerging therapeutics and treatment modalities

Li-Yen Lee $^{1 \#}$, Geena Suet Yin Hew ${ }^{1 \#}$, Meenu Mehta ${ }^{2 \#}$, Shakti D Shukla ${ }^{3}$, Saurabh Satija ${ }^{2,4}$, Navneet Khurana ${ }^{4}$, Krishnan Anand ${ }^{5}$, Harish Dureja ${ }^{6}$, Sachin Kumar Singh ${ }^{4}$, Vijay Mishra ${ }^{4}$, Pankaj Kumar Singh ${ }^{7}$, Monica Gulati ${ }^{4}$, Parteek Prasher ${ }^{8}$, Alaa AA. Aljabali ${ }^{9}$, Murtaza M Tambuwala $^{10}$, Lakshmi Thangavelu ${ }^{11}$, Jithendra Panneerselvam ${ }^{12}$, Gaurav Gupta ${ }^{13}$, Flavia C. Zacconi $^{14}$, Madhur Shastri ${ }^{15}$, Niraj Kumar Jha ${ }^{16}$, Dikaia Xenaki ${ }^{17}$, Ronan MacLoughlin ${ }^{18,19,}$ ${ }^{20}$, Brian G Oliver ${ }^{17,21}$, Dinesh Kumar Chellappan ${ }^{2 *}$, Kamal Dua ${ }^{2,3,23 *}$

${ }^{1}$ School of Pharmacy, International Medical University (IMU), Bukit Jalil 57000, Kuala

Lumpur, Malaysia

${ }^{2}$ Discipline of Pharmacy, Graduate School of Health, Uni rers y of Technology Sydney, NSW 2007, Australia

${ }^{3}$ Priority Research Centre for Healthy Lungs, Hunter Nidical Research Institute (HMRI), University of Newcastle, New Lambton Heights, Newnde, NSW 2305, Australia

${ }^{4}$ School of Pharmaceutical Sciences, Lovely r f fessional University, Phagwara-144411, Punjab, India

${ }^{5}$ Department of Chemical Pathology, S ho $\mathrm{sl}$ of Pathology, Faculty of Health Sciences and National Health Laboratory Service, I' 'niversity of the Free State, Bloemfontein, South Africa ${ }^{6}$ Department of Pharmaceutical Sci n` _ Maharshi Dayanand University, Rohtak, Haryana, India-144411

${ }^{7}$ Department of Pharmaceutics, Natıonal Institute of Pharmaceutical Education and Research (NIPER), Hyderabad, Telai. sani 500037

${ }^{8}$ Department of Chemis ry, Jniversity of Petroleum \& Energy Studies, Dehradun 248007, India

${ }^{9}$ Department of Pharmaceutical Sciences, Faculty of Pharmacy, Yarmouk University, Irbid, Jordan

${ }^{10}$ School of Pharmacy and Pharmaceutical Sciences, Ulster University, Coleraine, County Londonderry, BT52 1SA, Northern Ireland, United Kingdom

${ }^{11}$ Nanobiomedicine Lab, Department of Pharmacology, Saveetha Dental College, Saveetha Institute of Medical and Technical Sciences, Chennai, 600077, Tamil Nadu, India ${ }^{12}$ Department of Pharmaceutical Technology, International Medical University (IMU), Bukit Jalil 57000, Kuala Lumpur, Malaysia 
${ }^{13}$ School of Pharmacy, Suresh Gyan Vihar University, Jagatpura, Jaipur 302017, India

${ }^{14}$ Departamento de Organica, faculdad de Quimica y de Farmacia, Pontificia Universidad

Catolica de Chile, Santiago, Chile

${ }^{15}$ School of Health Sciences, College of Health and Medicine, University of Tasmania, Launceston, TAS 7250, Australia

${ }^{16}$ Department of Biotechnology, School of Engineering \& Technology (SET), Sharda University, Greater Noida 201306, India

${ }^{17}$ Woolcock Institute of Medical Research, University of Sydney, Sydney, New South Wales, Australia

${ }^{18}$ Aerogen, IDA Business Park, Dangan, H91 HE94, Galway, Irel; nd

${ }^{19}$ School of Pharmacy \& Biomolecular Sciences, Royal C, 1leg : of Surgeons in Ireland, D02 YN77 Dublin, Ireland

${ }^{20}$ School of Pharmacy and Pharmaceutical Sciences, '1, in Ireland

${ }^{21}$ School of Life Sciences, University of Tc hnorogy Sydney, Sydney, New South Wales 2007, Australia

${ }^{22}$ Department of Life Sciences, Schoc. of Pharmacy, International Medical University (IMU), Bukit Jalil 57000, Kuala Lumpur, N al ‘ ‘sia

${ }^{23}$ School of Pharmaceutical Scier ces, snoolini University, Solan, Himachal Pradesh, 173229, India

\#Authors sharing first authe "shi, in equal contribution

*Corresponding authors:

Dr Dinesh Kumar Chellappan, Department of Life Sciences, School of Pharmacy, International Medical University, Bukit Jalil 57000, Kuala Lumpur, Malaysia.

Tel.: +60126361308, E-mail: dinesh_kumar@imu.edu.my

Dr Kamal Dua, Discipline of Pharmacy, Graduate School of Health, University of Technology Sydney, NSW 2007, Australia.

Tel.: +61295147387, E-mail: Kamal.Dua@uts.edu.au

Prof Brian G Oliver, ${ }^{17}$ Woolcock Institute of Medical Research, University of Sydney, Sydney, New South Wales, Australia

Email: Brian.Oliver@uts.edu.au 


\begin{abstract}
Eosinophils are bi-lobed, multi-functional innate immune cells with diverse cell surface receptors that regulate local immune and inflammatory responses. Several inflammatory and infectious diseases are triggered with their build up in the blood and tissues. The mobilization of eosinophils into the lungs is regulated by a cascade of processes guided by Th2 cytokine generating T-cells. Recruitment of eosinophils essentially leads to a characteristic immune response followed by airway hyperresponsiveness and remodelling, which are hallmarks of chronic respiratory diseases. By analysing the dynamic interactions of eosinophils with their extracellular environment, which also involve signalling molecules and tissues, various therapies have been invented and developed to target respirntrry diseases. Having entered clinical testing, several eosinophil targeting therapeutic agents $\cdots$ ve shown much promise and have further bridged the gap between theory and practic e. Nr ieover, researchers now have a clearer understanding of the roles and mechanisr is it eosinophils. These factors have successfully assisted molecular biologists to block sreci.c pathways in the growth, migration and activation of eosinophils. The primary $\operatorname{pur}_{1} \mathrm{c}_{\mathrm{s}} \mathrm{e}$ of this review is to provide an overview of the eosinophil biology with a special -1. oh $\mathrm{c}$ sis on potential pharmacotherapeutic targets. The review also summarizes promisin $\iota_{c}$ eosinophil-targeting agents, along with their mechanisms and rationale for use, in ${ }^{1}$ uding those in developmental pipeline, in clinical trials, or approved for other respiratur $/$ c isorders.
\end{abstract}

Keywords: Respiratory diseas s; Pulmonary; Eosinophils; Targeted therapies; Immunity; Lung 


\subsection{Introduction}

\subsection{Role of eosinophils in host defense and immunity}

In 1879, Paul Ehrlich was the first person to recognize the unique ability of eosinophils to stain using acidophilic dyes (1). For many years, they were recognized as cells with end-stage effector functions in helminth infections and tissue damage (1). However, the plethora of clinical studies carried out in previous years have helped establish the crucial role of eosinophils in host defense, allergic inflammation, innate and adaptive immunity $(1,2)$. Importantly, the interaction of eosinophils with B-cells allo 's them to process antigens, stimulate T-cells and induce humoral responses (1). Inflamm ior ; and adaptive responses can also be initiated by eosinophils through their bidirectior al interactions with dendritic cells (DCs) and T-cells (3). Activated eosinophils are able th release a large assortment of newly synthesized as well as pre-formed mediators, such : s cy otoxic granule proteins, cytokines, chemokines, and lipid mediators which contributes to the various activities of eosinophils in inflammatory and infectious responses (4).

Eosinophils are now recognize $\lrcorner$ a, regulatory cells with the proven ability to influence and enhance local inflammation, instead of just simply effector granulocytes with cytotoxic activities (5). The immunoman ${ }^{1}$ atory role played by eosinophils include mediating aluminum hydroxide-induced B-r-11 r ming, acting as an antigen-presenting cell (APC) for T-cells, influencing T-cell diff re $_{\text {. }}$-iation (i.e. Th1 or Th2), and recruiting T-cells, DCs and macrophages to inflammatory ites in the host $(6,7)$. Eosinophils were shown to regulate DCs and Th2 pulmonary imm un response following an allergen challenge in mouse models (8). Moreover, a unique incion of eosinophil is the suppression of DC-mediated Th17 production (8). Thus, eusinophils are important modulatory cells to maintain the equilibrium between DC-mediated Th2 and Th17 signaling pathways following an allergen exposure and subsequently, the allergic airway inflammation progression (8). Recently, it was discovered that eosinophils are necessary for the long-term preservation of plasma cells in the bone marrow and eosinophil depletion induces bone marrow plasma cells apoptosis (9). Wu et al., also reported that eosinophils regulate glucose homeostasis by preserving adipose tissue alternatively-activated macrophages (AAMs) via the secretion of IL-4 cytokine (10). As a regulator of innate immune response, eosinophils are also responsible for apoptotic cell clearance in the thymus (11). 
Similar to other granulocytes, eosinophils undergo development and differentiation in the bone marrow (12). Upon maturation, eosinophils are distributed in various organs in the body, such as blood, lung, uterus, thymus, spleen, mammary gland, adipose tissue, and gastrointestinal tract (GI), to carry out their physiological functions under homeostasis $(6,12)$. The recruitment of mature eosinophils from the systemic circulation to the inflammatory sites occurs following the overexpression of eosinophil-specific chemokines in response to stimuli (12). Interleukin-5 (IL-5) is the most important cytokine responsible for eosinophil differentiation, priming and survival and its main sources of production are type 2 T-helper (Th2) cells and type 2 innate helper lymphoid cells (ILC2) $(6,12)$.

\subsection{Cytokines, chemokines, receptors, and surface markeı :}

A broad variety of cytokines, lipid mediators and c ther major molecules are expressed and secreted by eosinophils (Figure 1). These molecriles are stored in eosinophilic granules and rapidly secreted in response of a specific tinuli, hence altering the external microenvironment and cellular functions. To inophils are distinguished from other lymphocytes, such as T-cells and B-cells, duc to tneir ability to store and rapidly release preformed cytokines within minutes in es ponse to stimuli $(13,14)$. Besides pre-formed cytokines, eosinophils can carry out ¿'o novo synthesis and secretion of other immunological factors (14). It was hypothesized $n n_{*}$ the binding of soluble N-ethylmaleimide sensitive factor attachment protein recep or (SNARES), which are part of the membrane fusion complexes, regulates the fina' steps of cytokine secretion from eosinophilic crystalloid granules and secretory vesi 1 es 1 i4).

Eosinophils are a maior sou ce of IL-5 cytokine, which is important for its differentiation, survival and chemotaxı (15). Other Th2 immunomodulatory cytokines secreted by eosinophils include IL-4 and IL-13 (13). Besides Th2 cytokines, other cytokines with Th1 and regulatory capacities released by eosinophils include IL-6, IL-10, IL-12, TNF- $\alpha$, TGF- $\beta$, and IFN- $\gamma$ (13). IL-6, IFN- $\gamma$, and TNF- $\alpha$ causes tissue damage through their proinflammatory actions whereas TGF- $\beta$ contributes to airway remodeling via its role in epithelial changes, subepithelial fibrosis and microvascular changes $(16,17)$. As for the lipid mediators, eosinophils releases a large quantity of prostaglandins, leukotrienes, and plateletactivating factors (PAF) (16). Eosinophils express a wide variety of receptors and molecular surface markers on their cell surfaces, including IL-5R $\alpha$, prostaglandins (CRTH2), CCchemokine receptor (CCR)-3, sialic acid-binding immunoglobulin-like lectin 8 (SIGLEC-8), 
leukotriene B4 receptors (IL-4R, IL-5R, IL-33R, IFN- $\gamma$ R, TGF- $\beta R$, CCR1, CCR3, CCR4, and TSLPR), PAF-receptor, Fc $\alpha$ R, Fc $\gamma$ R, and pattern-recognition receptors (PRRs) (18). The most prominent cytokine receptor present on human and mice eosinophils is IL-5R $\alpha$ where the main receptors which define the distinct biology of eosinophils are CCR3 and SIGLEC-8 (19). Human eosinophils uniquely express SIGLEC-8 and the binding of antibodies or glycan ligands with this structure leads to apoptosis of eosinophils (20). The PRRs families expressed by human eosinophils include Toll-like receptor (TLR) family (TLR1-5, TLR7, TLR9), C-type lectin receptor (CLR) (Dectin-1), nucleotide-binding oligomerization domain (NOD)-like receptors (NOD1, NOD2), and receptors for advanced glycation end-products (RAGE) (19,21,22). Interaction with eosinophilic PRRs it ${ }^{\mathrm{H}} \mathrm{uces}$ eosinophil survival, oxidative burst, adhesion system activation, and mediator relt ase 21).

Integrins are cell surface proteins commonly foun ${ }^{1}$ on immune cells which functions to merge the intracellular and extracellular domain oi the immune system. Eosinophils express several integrins, such as $\alpha 4 \beta 1$ (CD49d/^乞29), $\alpha 6 \beta 1$ (CD49f/ CD29), $\alpha \mathrm{L} \beta 2$ (CD11a/CD18), $\alpha \mathrm{M} \beta 2$ (CD11b/CD18), $\alpha \mathrm{X} \beta 2$ ( /11c/CD18), $\alpha \mathrm{D} \beta 2$, and $\alpha 4 \beta 7$ (23). These integrins interact with not only their respectiv- ligands, but also vascular adhesion molecule 1 (VCAM-1), intracellular adhesion mole ㄱ, 1 (ICAM-1), periostin, laminin, and fibronectin

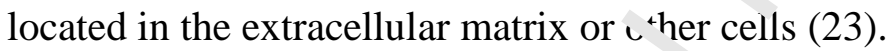

Furthermore, blood eosinopl ll : nnstitutively expresses selectins, including P-selectin glycoprotein ligand-1 (PSGL-1, C ?162) and L-selectin (CD62L) (24). A high level of surface P-selectin results in $\epsilon$ - sinophilic $\beta_{1}$ integrin activation in vivo and thus, stimulates eosinophilic adhesion to $\mathrm{VCAN}-1$ and migration to the airway (24).

Notch receptnrs and Votch ligands are also expressed on human blood eosinophils, which serve as important omponents for eosinophil autoregulation (25). A study showed that granulocyte-macrophage colony-stimulating factor (GM-CSF) influences the expression and activation of Notch molecules and thus, affects the activity and survival of eosinophils (25).

\subsection{Eosinophilic granule proteins}

Eosinophils store pre-formed enzymatic and non-enzymatic cationic proteins in large secondary granules which are selectively secreted in response to specific stimuli (26). The release of these granule proteins have typically be considered as the primary effector mechanism of eosinophils against specific parasites and in allergic inflammation (27). The antibacterial effect of eosinophils in vivo is specifically mediated thorough the release of cationic secondary granule proteins (28). This dominant population of cytoplasmic crystalloid 
granules containing cationic proteins distinguishes eosinophils from other leukocytes (29). The four notable granule proteins present in human eosinophils include eosinophil peroxidase (EPO), major basic protein (MBP), and eosinophil-associated RNases (EARs) which are eosinophil cationic protein (ECP) and eosinophil-derived neurotoxin (EDN) $(19,29)$.

EPO is the cationic protein present most abundantly in the matrix of the crystalloid granules (16). EPO contributes to eosinophil function by generating reactive oxidizing species (ROS) as well as acting as a direct toxin against mammalian cells and parasites (16). The promotion of oxidative stress by EPO results in cell apoptosis and necrosis $(19,30)$. A study carried out by Panagopoulos et al., reported that EPO and other peroxidases play a part in angiogenesis in addition to cellular proliferation, migration, and invasion (31). Ochkur et $a l$., also demonstrated the use of a sensitive and specific E' IS, for the detection of EPO (32).

MBP exerts direct toxicity which contributes to its function in altering membrane permeability and enzyme functions in mammalian ce $i^{-}$.nicrobes, and helminths $(16,19)$. As for its role in the pathophysiology of asthma, $\left.M^{\top}\right\lrcorner$ induces bronchoconstriction and epithelial tissue damage (16). MBP was also reported to have pro-angiogenic effects in vitro and in vivo (33).

ECP and EDN are part of the 1' honuclease A superfamily (16). EDN demonstrates cytotoxicity, neurotoxicity, and ant $\mathrm{v} . .^{1}$ activity (single-stranded RNA virus), but it exerts low toxicity towards mammalian ct:'s and parasites (16). Tsuda et al., recently reported that EDN stimulates matrix metalle , roteinase 9 (MMP-9) production from nasal epithelium, thus indicating its potential role $i n$th $e$ pathogenesis of eosinophilic chronic rhinosinusitis (ECRS) (34). Conversely, ECP s ow distinct toxicity towards a large variety of bacteria, helminths, single-stranded RNA viı ises, and host tissues (16). ECP exerts its toxic effects through formation of pores in target membranes (19). Besides its cytotoxic effects, ECP also stimulates airway mucus hypersecretion and mast cell degranulation, as well as suppresses Bcell immunoglobulin synthesis and T-cell proliferative responses (19). EDN is known to possess multifunctional properties and may contribute to innate immunity by either killing or inactivating viral invaders (35). In 1998, the potential of EDN as an antiviral agent against respiratory syncytial virus was demonstrated under in-vitro settings (36). Domachowske and colleagues demonstrated a dose-dependent decline in the infectivity of respiratory syncytial virus B after the introduction of eosinophils into the viral suspension (36). Interestingly, the inclusion of ribonuclease inhibitor was found to reverse the antiviral effect observed by eosinophils, suggesting a role of EDN (eosinophil secretory ribonuclease). The suggestive 
antiviral role of EDN was confirmed when a 40-fold decrease in infectivity, after the introduction of EDN into the suspension of respiratory syncytial virus B was obtained. Importantly, the inactivated form of EDN was reported to have no antiviral effects. Furthermore, the observed antiviral activity of EDN was found to be the direct ribonucleolytic destruction of extracellular virions. These findings collectively suggest that EDN may also be used as a therapeutic agent for the management of respiratory syncytial virus (36). Furthermore, Rugeles et al., reported that EDN was responsible for the majority of anti-HIV-1 activity shown by alloantigen-stimulated factors in the supernatant of mixed lymphocyte reactions (37).

Additionally, another important protein found in prim ry granules of eosinophils is galectin-10, or Charcot-Leyden crystal protein. Galect n-1) was shown to be strongly associated with sputum eosinophilia and hence, can inction as a potential alternative biomarker of eosinophil-associated airway inflammatı $\left.{ }^{n}, 38\right)$.

\subsection{Degranulation}

The extracellular release of eosi. $\urcorner$ r.illic granule proteins is termed as degranulation. Piecemeal degranulation (PMD) is g nerally acknowledged as the most prevalent manner of eosinophilic degranulation $(16,19)$ ' packaged into vesicles which ar $\doteq \iota\urcorner n s p o r t e d$ across the cytoplasm and fused with the cell membrane in order to extracc. 'ularly release the granule proteins at the cell surface (29). Cytokines and chemokines whi in induces PMD are IFN- $\gamma$, CCL-11 (eotaxin-1), and TNF- $\alpha$ $(16,39)$. Following the $r$ lea: e of its granule proteins via PMD, the eosinophil remains fully functional and responsive to other stimuli. An example of PMD is the release of IL-4 from eosinophils stimulated with eotaxins, whereby secretory vesicles deliver IL-4/IL-4R $\alpha$ complex, which is initially formed inside the granule membrane, to the cell surface and subsequently released into the extracellular space (19).

Another mechanism of degranulation observed in eosinophils is associated with cytolysis, in which the eosinophil undergoes cell lysis in a manner that morphologically differs from either apoptosis or necrosis, thus releasing intact, cell-free, membrane-bound granule proteins which are fully competent (29). The manner of cell death in eosinophilic cytolysis is termed as extracellular trap cell death (ETosis), whereby the nuclear membrane disintegrates and DNA de-condenses into the surrounding cytoplasm (16). Cytolysis is 
acknowledged as a common method for the release and deposition of cell-free eosinophilic granules in eosinophil-associated disorders (29).

Lastly, eosinophil degranulation can also occur by classical exocytosis, in which the fusion of intracellular granules with the plasma membrane precedes the extracellular release of the total granule contents (40). This mechanism of degranulation does not occur commonly in eosinophilic diseases, except in the presence of parasitic helminths or specific fungi (40).

Although degranulation is the primary mechanism in which eosinophils exert their function, this process does not occur during transit in blood circulation. Instead, granules are commonly released when the eosinophils arrive at the site of inita mmation (41).

\subsection{Hypereosinophilic syndromes}

Hypereosinophilic syndromes (HES) comprice of a heterogenous collection of disorders with common features of elevated blood an ${ }^{\mathrm{N}}$ - ssue eosinophils and tissue damage $(42,43)$. The clinical manifestations are variable as $\mathrm{J}$ may include any organ system, but most commonly the skin (42). Since 1975, the a finıtıon of HES includes 3 criteria: (i) blood eosinophil count $\geq 1500 / \mathrm{mm}^{3}$ for $>6 \mathrm{ml}^{n t^{t}}$ s (or mortality within 6 months associated with signs and symptoms of hypereosinophilic disease), (ii) insufficient evidence of other causes of eosinophilia (e.g. parasite, allerg ). «nd (iii) presumptive signs of organ involvement (e.g. GI dysfunction, heart failure, cer crai nervous system impairment, weight loss, or fever) (44). However, there are several shu ${ }^{+}$connings with these definitions of HES. Marked eosinophilia is typically caused by $1.1 \mathrm{~lm}$ ith infections, but other non-infectious causes include malignancies, drug react ons. immunologic, allergic and inflammatory diseases (45).

\subsection{Eosinophils and ast ma}

\subsection{Eosinophils in the Pathophysiology of Asthma}

\subsubsection{Eosinophilic asthma}

Asthma is an inflammatory respiratory disorder outlined by airway hyperresponsiveness (AHR), airway obstruction, mucus hypersecretion, airway inflammation, tissue damage and airway remodeling (16,46-48). According to a study conducted by the Global Burden of Disease (GBD), it was estimated that around 339.4 million people globally were affected by asthma in 2016 (49). Eosinophils have been closely related to the pathophysiology of asthma, as reported from the elevation of eosinophil numbers in peripheral blood and bronchoalveolar lavage fluid (BALF) of asthmatic patients 
$(16,46)$. In a certain percentage of patients, eosinophilic airway inflammation represents the occurrence of bronchial asthma (50). Eosinophils are pro-inflammatory granulocytes with major contributions to the inflammatory responses of asthmatic patients, especially in T2high asthma phenotypes such as severe eosinophilic asthma, by releasing inflammatory mediators to trigger an inflammatory cascade as well as exerting toxic effects directly on host tissues (51). Severe asthma is a heterogenous disorder as different phenotypes exists, such as eosinophilic asthma. Eosinophilic asthma can be clinically characterized by its severity and frequent exacerbations (50). Additionally, other features of eosinophilic asthma includes sputum and airway eosinophilia, elevated blood eosinophil count, adult-onset, and involvement of nasal polyps-associated chronic rhinosinusitis iı $50 \%$ of the patients $(51,52)$. Conversely, non-eosinophilic asthma can be characterized by low eosinophil counts, with the dominant inflammatory cell type being neutrophils and mi ed granulocytes, or very few inflammatory cells (51). Generally, the higher the rogse of eosinophilia, the greater the disease severity and exacerbation frequency in eos1. ^r.tilic asthma (46). Eosinophilic and paucigranulocytic asthma (asthma with very fev 11 lammatory cells) are among the dominant inflammatory asthma phenotypes.

\subsubsection{Eosinophil recruitment, migrat心 $\eta$, development, and survival}

In eosinophilic asthma, whic 1 , also known as Th2 asthma, eosinophils present as the hallmark as seen in their elevatt.' numbers (Figure 2) (53). The exposure of airway epithelium to allergens or a.tigens triggers an immunological cascade which attracts eosinophils to the airway by Th2 cytokines and chemoattractants (16). Th2 cytokines secretion contributes to i he is crease in eosinophil counts in the BALF as they are responsible for eosinophil recruitme t, migration and survival (16). The Th2 cytokines which induces eosinophil migration to the airways include IL-4, IL-5 and IL-13, which are produced by activated Th2 lymphocytes and ILC2s (16,53). Among them, IL-5 and the chemokine eotaxin-1 (CCL11) are the primary mediators for the release of bone marrow eosinophils and trafficking of eosinophils to the lungs (16,51). Eotaxin is produced by allergen-challenged endothelial and epithelial cells and enhances eosinophil migration by binding to CCR3 expressed on its surface (16). Besides stimulating eosinophil migration, IL-5 is also an important mediator of eosinophils differentiation, development, activation and survival $(52,54)$. Other major sources of IL-5, other than Th2 cells and ILC2s, are CD34+ progenitor cells, mast cells, invariant natural killer (NK) T-cells, and eosinophils themselves (55). In addition to the regulation of eosinophil numbers, IL-5 produced by ILC2s also regulates their 
circadian cycling (55). IL-4 and IL-13 do not directly mediate eosinophil trafficking; IL-4 sustains eosinophil migration by inducing B-cell isotype switching to immunoglobulin (Ig)E for the development of Th2 lymphocytes whereas IL-13 stimulates eotaxin production (53). IL-4 also induces the expression of VCAM-1 and eotaxin by epithelial cells which enhances eosinophil migration to the site of allergic inflammation (16). study by Beckert et al., provides evidence on the effects of the Th2 cytokines, either alone or in combination, on eosinophils in a mouse model (56). C57BL/6 mice were intranasally administered equimolar amounts of single agent or combination IL-4, IL-5 and IL-13. The results demonstrated that IL-4 and IL-13 were correlated with airway eosinophilia, progression of airway hyperresponsiveness, and goblet cell metaplasia (56). Howevi, IL-4 demonstrated weaker effects than IL-13 and no synergism was observed wh?n hese two cytokines were administered in combination (56). After the administratic $\eta$ of IL-5, it was observed that the eosinophil count in bone marrow and lung tissues were in reased but no structural changes of the eosinophils were observed (56). The combin d administration of IL-5 and IL-13 significantly increased the number of lung, a ${ }^{\prime} \mathrm{dv}$, blood and bone marrow eosinophils, whereas IL-5 and IL-4 combined only increas 'd eosinophils count in lungs and bone marrow (56).

Besides Th2 cells, the dann aed epithelial cells also contributes to eosinophils recruitment through the release of $\mathbf{L} \cdot: 5$ IL-33, and thymic stromal lymphopoietin (TSLP) (16). These cytokines activate IL $\angle \subset$ from the innate immune system to secrete IL-4, IL-5 and IL-13 (16). Additionally, IL-32 and granulocyte-macrophage colony-stimulating factor (GMCSF) contributes to eosino ${ }_{\mathrm{r}}$ hils ifferentiation and migration as well as mediate their survival in the airways (16) I , - 3 s directly stimulates eosinophil differentiation from CD $117^{+}$ hematopoietic progenito cells and contributes to the exacerbation of eosinophilic inflammation by elevating eosinophil, macrophage, lymphocyte, IL-13, TGF- $\beta$, CCL3, CCL17, and CCL24 levels in the airways (57). IL-18 was also recently identified as an important cytokine for the production, differentiation, and maturation of $\left(\mathrm{CD} 101^{+} \mathrm{CD} 274^{+}\right)$ pathogenic eosinophils (54).

Fanat et al., researched the effects of cells sourced from human airway smooth muscle (HASM) on eosinophils (58). In this study, peripheral blood progenitor cells collected from atopic asthmatics and control subjects with no atopy were cultured together with supernatant collected from HASM cells culture. At the end of the study, it was observed that HASM cellderived cytokines stimulated eosinophil differentiation via the p38 mitogen-activated protein kinase (MAPK) pathway but not the src kinase ( $\mathrm{srcK}$ ) pathway (58). The cytokines released 
by HASM cells were identified to be IL-5 and GM-CSF as eosinophil differentiation was inhibited by anti-IL-5 and anti-GM-CSF blocking antibodies (58). Thus, the researchers concluded that HASM cells have the ability to modulate differentiation and maturation of eosinophils from precursor cells including immature eosinophils, that may lead to eosinophilic inflammation and airway remodeling in severe asthmatics (58). However, haemopoietic progenitor cell migration and adhesive response in vitro are not influenced by HASM cells. (58).

Lung dendritic cell (DC) subsets also play a role in initial eosinophil recruitment to the site of allergen challenge. A specific sub-type of DCs in the lung, i.e., CD24CD11b DC2s, produce NO synthase which induces CCL17 and CCLi? on lung CDC1s to attract eosinophils for initial eosinophil infiltration. After the alle gen challenge, eosinophil recruitment is inhibited by lung $\mathrm{CD} 24 \mathrm{cDC} 2 \mathrm{~s}$ through ' $\mathrm{GF} \beta 1$ secretion (59). Hence, the impaired expression of CCL17 and CCL22 lead to the 1:sponse seen during the late phase reaction. It was suggested that different lung APCs st.a specific soluble factors during the memory stage of chronic asthma after an alle $g \rho$ challenge, thus regulating lung $\mathrm{cDC} 1-$ mediated eosinophil recruitment differentlv ( $(5)$ ).

Several lipids, such as prostag ${ }^{\prime} \eta^{\prime}$ ins and leukotrienes, are key mediators of the inflammatory response by acting is chemoattractant(s) of eosinophils. For example, leukotriene E4 and prostaglandin 'J2 (PGD2) induce eosinophil migration to the airways (16). PGD2 acts by binding to $\mathrm{C}^{\top} 7 \mathrm{H} 2$ receptor (DP2) in eosinophils which induces its recruitment and activation (16).

Nitric oxide (NO) s:'nth :sized from epithelial cells and vascular endothelial cells by inducible nitric oxide sy tha e enzyme is also responsible for the recruitment of eosinophils in addition to its function as a mediator of inflammation, and this correlates with the level of exhaled NO, which is a biomarker of asthma (16).

Following the recruitment phase comes the effector phase. Autocrine secretion of IL5 by activated eosinophils enables them to survive within tissues in their own capacity as the secreted IL-5 inhibits apoptosis (16,60). Moreover, the adherence of eosinophils to fibronectin stimulates the secretion of other pro-survival mediators, such as GM-CSF and IL3 , by activated eosinophils and hence, promotes their own survival $(16,60)$. The additional effects of these cytokines enable eosinophils to persist in the airways for long periods and prolong their effects. 
Eosinophils in inflamed tissues are also activated by antigen-specific IgGs and IgAs, but not IgE, as reported by a study conducted on the effects of antigens and antigen-specific immunoglobulins on eosinophil function (61).

\subsubsection{Airway hyperresponsiveness (AHR) and Mucus Hypersecretion}

AHR occurs when there is a dysregulation of airway homeostasis. Allergen exposure causes events such as airway epithelium damage, mucus hypersecretion and ASM proliferation which leads to homeostasis imbalance (62). Eosinophils are highly involved in the development of these events through the release of its granule cytotoxic proteins via cytolysis, such as MBP, EPO, ECP, and EDN (51,53). The relense of these granule proteins was shown to be triggered through chemokines, including ( otas in-1 and interferon-gamma $(\mathrm{IFN}-\gamma)$ (53). MBP presents as two type of homologs, which are MBP-1 and MBP-2, with MBP-1 having a significantly alkaline $\mathrm{pH}$ and exerting 'irect cytotoxic effects on the host cells (51). MBP-1 also has a greater potency in $h_{L^{\circ}}{ }^{+n}$. nine induction and leukotriene $\mathrm{C} 4$ release from basophils as compared to MBP-2 $(1)$. MBP and EPO were reported to cause AHR, although ECP and EDN did not (46). Ii was also reported that MBP induces bronchial hyperactivity by stimulating the release $\mathrm{I}$ / listamine from mast cells and basophils $(46,51)$. MBP can also cause bronchoconstric: on by blocking acetylcholine receptor, M2, which is a negative feedback regulator for a ef $y$ ' ^holine (53). Moreover, the combination of EPO, halides and hydrogen peroxide $\mathrm{Na}$ s shown to stimulate the release of mast cell mediators (51).

In addition to cytot vic ationic proteins, eosinophils secrete several cytokines which can contribute to the $h$. $11 \mathrm{~m}$ rks of asthma. For example, IL-13 is a cytokine released by eosinophils which can snhance the differentiation of goblet cells to promote mucus hypersecretion, as well as cause AHR. Moreover, Th2 cells and ILC2 also produces IL-13 (46).

Additionally, eosinophils also produce lipid mediators in eosinophil lipid bodies, such as leukotrienes, which can also cause AHR and mucus hypersecretion (46). Eosinophilic leukotrienes stimulate bronchoconstriction and activation of basophils and mast cells, which further sustains the ongoing inflammation via the secretion of histamine, prostaglandins, and additional leukotrienes (53).

The role of eosinophils in airway remodeling is further reinforced when mouse studies showed that mice with congenital eosinophil deficiency did not experience collagen and smooth muscle deposition in the airways (46). 


\subsubsection{Tissue damage and Airway remodeling}

Eosinophils cause persistent inflammation in the airways which causes continuous damage to the airway walls (53). During the reconstruction of the damaged airway, airway remodeling occurs as the basement membrane thickens and fibrosis occurs due to airway smooth muscle proliferation, goblet cell hyperplasia, extracellular matrix (ECM) proteins deposition, and new blood vessels formation (angiogenesis) (16,46,53). Airway remodeling is commonly associated with severe asthma phenotypes (63).

Tissue damage occurs as a result of the cytotoxic effects of the eosinophilic granule proteins. The granule proteins exhibit varying strengths of tw icity when tested in vitro. MBP, EPO and ECP exert toxicity to several tissues, inclu'ing bronchial epithelium, skin, heart and brain, whereas EDN only exhibits marginal toxi ity 151). MBP, EPO and ECP were found to cause damage to epithelial cells in vitro when ey 'ivalent concentrations as found in asthmatic patients were administered $(16,53)$. EC? ${ }_{1} \mathrm{~S}$ able to bind to and alter the permeability of cell membranes in the airway $(4)$.

The process of airway remodeling is lso contributed by TNF- $\alpha$, as well as IL-1- $\beta$ according to recent studies, which activa ${ }^{\text {`s }}$ eosinophils and stimulates the secretion of matrix metalloproteinase-9 (16,53). TNF- $\sim$ and IL-1- $\beta$ are also associated with persistent eosinophils recruitment (53). TGF. 3 s $?$ growth factor secreted by eosinophils which can promote airway remodeling. $\mathrm{Br}$ nn:-ial biopsies from asthmatic patients have shown that eosinophils are the primary su 'Irce TGF- $\beta$ (46). Studies have shown that TGF- $\beta$ mRNA expression was upregulatea in s zvere asthmatics and has correlation with the thickness of the basement membrane ' 16 ; T T iF- $\beta$ fucntions as a chemoattractant for fibroblast and stimulates fibroblast proliferation a ld differentiation into myofibroblasts and smooth muscle cells $(46,53)$. Additionally, TGF- $\beta$ upregulates the synthesis of collagen and glycosaminoglycans leading to ECM production and resulting in tissue remodeling of the airways $(46,53)$.

Besides granule proteins and cytokines, eosinophils also secrete reactive oxidant species (ROS), such as hydrogen peroxide, superoxide anion and hydroxyl radicals, which contributes to airway inflammation and airway remodeling by damaging the cells and tissues of the airways and inducing the fibroblast hyperplasia (16,51,53). EPO stimulates the production of cytotoxic ROS by catalyzing the oxidation process of halides and thiocyanate (46). 
Zagai et al., stated that conditioned media (CM) collected from cultured human peripheral eosinophils and eosinophil cationic protein (ECP) extracted from human peripheral eosinophils significantly stimulated the migration of human lung fibroblasts in vitro in a concentration- and time-dependent manner (64). Thus, it was suggested that eosinophils affect the fibrotic response in asthmatics. As airway remodeling is associated with fibroblast recruitment, it was proposed that the stimulation of fibroblast migration by ECP may be an important mechanism in the remodeling process of extracellular matrix leading to airway fibrosis in asthmatics.

\subsubsection{ASM proliferation}

The co-culture of eosinophils isolated from ast ma patients and ASM cells demonstrated an enhancement of ASM proliferation, wh ch $;$ inhibited by the presence of leukotriene antagonist, montelukast (46). A mutual rolainship exists between eosinophils and ASM cells as ASM cells are able to produce eosin ' '.ilic cytokines (46).

Based on the study done by Halwani et aı, cysteinyl leukotrienes (CysLTs) released from eosinophils when they are in direct cc. tact with airway smooth muscle (ASM) cells enhanced ASM proliferation (65). The $1 \mathrm{v} v$ rement of direct cell contact between eosinophils and ASM cells to trigger CysLTs rein ase were further confirmed when the administration of anti-adhesion molecule antibodies $\mathrm{r}, \mathrm{s}$ lted in the inhibition of ASM proliferation (66). Additionally, it was proven that tne : ncrease in ASM proliferation was dependent on CysLTs released from eosinophils inste d or ECM proteins as ASM proliferation was inhibited when leukotriene receptor antag nist (Montelukast) was co-cultured with eosinophils and ASM cells. The researchers concluded that airway remodeling in asthmatic patients can be attributed to eosinophil a rrived CysLTs which function to increase ASM mass through the enhancement of ASM proliferation.

\subsubsection{Eosinophilic pro-inflammatory cytokines and chemokines}

Besides the direct cytotoxic effects of eosinophilic granule proteins on tissues, eosinophils produce and secrete a variety of pro-inflammatory mediators which contributes to the pathophysiology of asthma. For example, eosinophils produce a variety of Th2 cytokines in the airways of asthmatics, including IL-4, IL-5, and IL-13 (51). The recruitment of leukocytes to the airways is also regulated via the secretion of eosinophilic chemokines, such as CCL3, RANTES (CCL5), and eotaxin (CCL11) (51). Alternatively, neutrophil recruitment is induced by IL-8 and GM-CSF, which are also expressed by eosinophils following an 
allergen challenge (51). Eosinophil activation is also mediated via Th1 cytokines released by eosinophils themselves, which is IFN- $\gamma$ (51). Thus, it is evident that eosinophils exhibit pleiotropic effects, which includes destruction of host tissues, regulation and potentiation of inflammatory pathways, as well as host defense. The severity of asthma symptoms in patients is worsened by these eosinophilic functions. Therefore, therapies which target eosinophils can be a potential intervention for asthma and other eosinophilic inflammation-associated diseases.

\subsection{Eosinophils as Biomarkers of Asthma}

Heterogeneity exists in asthma with regards to $i_{\mathbf{v}}: u^{\prime}$ derlying pathophysiology, clinical signs and symptoms, and treatment response. Th use of merely clinical and physiological assessment has become inadequate in tho ac urate prediction of the underlying mechanism of the disease or the treatment response. Th $\mathrm{us}$, additional testing for biomarkers in conjunction with examination of clinical sigr $s$ d symptoms of the patient will be able to help identify asthma phenotypes and endoty. ${ }_{1}$ es, anticipate the disease progression and its prognosis, as well as enhance the precis in therapy for asthma (67). Eosinophil counts have become a useful biomarker in the assu sment of asthma.

Szefler et al., reported that ih ; measurement of total eosinophil counts and sputum eosinophils as biomarkers for as $\mathrm{hH}^{\text {? }}$ are recommended as supplemental outcome measures (68). Supplemental outcome measures are defined as outcomes of asthma for which standardized definitions ar. ${ }^{1}$ sp :cific methods of measurement exists, and their validity has been proven but they res ain as an optional inclusion in funded clinical asthma research (68). The eosinophil measure ents are obtained through complete blood counts. In addition to sputum eosinophils, nasal discharge eosinophils with asthma symptoms may also be a predictive factor for persistent asthma (69). As such, testing for nasal discharge eosinophils with asthma symptoms increases with age (69).

The severity of sputum eosinophilia in asthma can be assessed using various biomarkers. However, the biomarkers' diagnostic accuracy might vary between different asthma phenotypes. Westerhof et al., carried out an investigation to determine the accuracy of several biomarkers for the detection of sputum eosinophilia in different phenotypes of adult asthma, such as total IgE, area under curve (AUC), and exhaled nitric oxide fraction (FeNO) (70). Among the different asthma phenotypes of adult patients used for comparison were severe and mild, obese and non-obese, atopic and non-atopic, and smoking/ex-smoker 
and non-smoking asthma patients. The findings showed similarities in AUCs for blood eosinophils and FeNO among the various asthma phenotypes whereas total IgE showed higher accuracy in the detection of sputum eosinophilia in non-obese and non-atopic asthmatics as compared to obese and atopic asthmatics (70). The researchers concluded that the measurement of blood eosinophils and FeNO as sputum eosinophilia biomarkers, irrespective of asthma phenotype, showed superior diagnostic accuracy as compared to total IgE (70). A separate study also showed that blood eosinophils can most accurately identify sputum eosinophilia in patients with varying severities of asthma, such as mild, moderate or severe asthma (71). Thus, eosinophils found in blood circulation can be used to facilitate individualized asthma treatments.

Nevertheless, some studies have shown that cespi e statistically significant associations, blood eosinophil and neutrophil counts, FeN $)$ ar $1 \mathrm{IgE}$ levels, FEV1 percentage and age are poor surrogate biomarkers, both singularly a $a^{\prime} d$ in a combination, for predicting sputum eosinophil and neutrophil percentages (72).

Phenotyping based on airway inflamm atj $\mathrm{n}$ severity is often applied to asthmatic patients. According to a study done by $\mathrm{W} 1 \mathrm{sh}$ et al., the relationship between rates of exacerbations and the phenotype of se, sr asthma was investigated based on longitudinal measures of sputum eosinophils and 1 sutrophils (73). The results demonstrated that asthmatic patients with persistent eosinophilir p. notype experienced shorter intervals before the first exacerbation and an increased ris $\mathrm{K} \mathrm{c}^{\mathrm{c}}$ exacerbation over a 1-year period as compared to those with non-eosinophilic phenoty ${ }_{\uparrow}$. However, no observable changes were noted in time to first exacerbation or exacerbatic ? ris s among neutrophilic phenotypes.

A cohort study arri d out in UK also reported that asthmatic patients with blood eosinophil numbers $>4 \omega$ cells $/ \mu \mathrm{L}$ experienced a worsening in asthma control and more severe exacerbations, as defined by the increased use of asthma relievers, asthma-related hospitalization, oral corticosteroids use, or antibiotics prescriptions (74).

Petsky et al., reported, in a systemic review, that carrying out therapy adjustment according to airway eosinophilic markers, such as sputum eosinophil counts and exhaled nitric oxide, significantly decreased the risk of asthma exacerbations (75). However, no significant impact was observed with regards to dose of daily inhaled corticosteroid, asthma control or lung function.

Periostin is a proposed novel biomarker of eosinophilic airway inflammation. A specific asthma subset as characterized by the expression of Th2 cytokine-inducible genes in bronchial epithelial cells was recently discovered. Periostin is included in this gene signature 
which is present in about $50 \%$ of asthma patients and is associated with eosinophil-mediated airway inflammation. In a study done by Jia et al., an assay for peripheral blood periostin protein was developed to investigate its potential as a biomarker in order to designate selective therapies for specific groups of asthma patients (76). The patients used for sample collection were asthmatics with persistent symptoms in spite of inhaled corticosteroid administration at maximum doses. The results showed that asthma patients with evident eosinophilic airway inflammation demonstrated a significant increase in levels of serum periostin as compared to those with minimal eosinophilic airway inflammation (76). Serum periostin levels also proved to be a more useful predictor of eosinophilia in airways than other indices, such as peripheral blood eosinophil, IgE and FeN $v$ levels (76). The researchers concluded that the occurrence of eosinophilic airway inflar mation can be predicted using periostin as a systemic biomarker in asthma patients and i hus, this can potentially be a utility for selecting patients for emerging asthmatic therane $\mathrm{e}^{+i c s,}$ such as ICS and biologics, targeting Th2 inflammation (76). Simpson et al., . 1s $J$ reported that serum and sputum periostin levels have high correlation with sr utum eosinophil counts (77). Periostin concentrations were also found to be higher is serum than in sputum. However, the ability of periostin levels to predict the presence or ac sinophilic asthma was modest.

Besides periostin, eosinophii neroxidase (EPO) level are also reported in several studies to have correlation with spu $\mathrm{u}_{1}$. eosinophil levels. Rank et al., carried out a study to compare nasal, pharyngeal, an $d$, nutum EPO levels with induced sputum eosinophil percentage and found that the 1 - was a strong association between nasal and pharyngeal EPO levels and the percentage if er sinophils of induced sputum. Another study carried out by Nair et al., concluded hat EPO levels assayed by ELISA was an appropriate surrogate marker of eosinophils anc 'or eosinophil degranulation in sputum of respiratory patients (78).

ILC2s are recognized as another novel biomarker for eosinophilic airway inflammation. In an investigation carried out by Liu et al., the inherent diagnostic ability of ILC2 was compared to standard biomarkers of eosinophilic asthma, including age, sex, BMI, number of blood eosinophils, IgE, and FeNO (79). The results concluded that ILC2 levels were significantly elevated in patients with eosinophilic asthma and the ILC2 percentage was the most significant component of eosinophilic airway inflammation as compared to the other biomarkers (79). Moreover, ILC2 percentage showed high sensitivity and specificity in differentiating patients with eosinophilic asthma from asthma patients without eosinophilic inflammation (79). Thus, ILC2 is a prospective substitute biomarker for eosinophilic airway inflammation in mild-moderate asthma patients and subsequently, can be used to select 
patients for beneficial asthmatic therapies targeting Th2 inflammation. There is a six-gene signature paper that predicts exacerbations in the severe asthma patients, this six-gene sig has been proposed as a marker for severe asthma exacerbations, and more recently in COPD $(80,81)$.

Biomarkers of eosinophilic inflammation appears to differ between severe asthmatic patients with concomitant obesity and normal asthmatic patients. In a study done by Desai et al., obese severe asthmatic patients demonstrated significant elevations in submucosal eosinophils and sputum IL-5, however no changes were observed in sputum eosinophils (82). Hence, supplementary investigations should be performed to determine if eosinophil-targeted therapies or diet and lifestyle modifications are more effective $i_{\imath 1}$ roviding anti-inflammatory effects in obese patients with asthma.

\subsection{Bacteria and eosinophils}

A greater diversity of microorganisms $w \cdot h$ altered compositions are known to be present in asthmatic patients, for example, ore Proteobacteria and less Bacteroidetes as compared to healthy subjects (83). Heı •e it was proposed that the composition of airway microbiome has correlations with th type of airway inflammation $(84,85)$. A study carried out by Sverrild et al., revealed $t^{\prime}$ ia the level of eosinophilic airway inflammation has correlations with the varying airv ay nıcrobiome constituents in asthma patients (83). A more abundant bacterial profile was vbtanned from patients with the lowest eosinophil counts, for example, a greater propor: in of Neisseria, Bacteroides, and Rothia species and a lower proportion of Sphingom ma: Halomonas and Aeribaccilus species as compared to asthma patients with greater eo inophil counts and healthy subjects (83). The type of bacterial species also affects eosinophil functionality differently. A study conducted by Hosoki et al., showed that Staphylococcus aureus (SA) stimulated the release of EDN in a dose-dependent manner, but Haemophilus influenzae (HI) and Prevotella sp. (PS) did not (86). SA, HI and PS all significantly enhanced superoxide generation, but SA had a greater effect which significantly induced a greater eosinophilic TNF- $\alpha$ production as compared to either HI or PS (86). Conversely, HI and PS induced IL-10 production more strongly than SA (86). Thus, it was concluded that SA may be associated with exacerbation of eosinophilic inflammation in asthma whereas HI and PS may be involved in its inhibition.

\subsection{Drugs targeting eosinophils in the treatment of asthma}


Asthma is conventionally treated with beta-agonists, anti-cholinergics and inhaled corticosteroids (ICS). In addition, biologics are commonly used as an alternative to treat severe and refractory asthma in which conventional treatments show limited efficacy or intolerable side effects. Monoclonal antibodies, such as those targeting IL-5, IL-5R $\alpha, \operatorname{IgE}$ and IL-4R $\alpha$, have shown favourable outcomes in clinical trials for the treatment of severe, uncontrolled asthma (87). Patients with severe eosinophilic asthma were also successfully managed with biologics which target IL-5, IL-4, IL-13, and IgE. This is because local eosinophilopoiesis is hypothesized to be the predominant mechanism that results in on-going airway eosinophilia and steroid requirements in patients with severe asthma, and these agents either directly or indirectly targets eosinophils which leads to inproved asthma outcomes, such as reduced exacerbations and steroid-sparing effects. t mo g these biologic therapies, anti-IL-5 drugs, including reslizumab, mepolizumab, an' be ıralizumab are most used and supported as adjuncts for severe eosinophilic asthma herapy and poor asthma control. Studies have shown that treatments that target IL-5, T. $5 \mathrm{R} \alpha$ in severe eosinophilic asthma patients resulted in significant decrease of $b^{1}$ oc $\mathfrak{d}$ and sputum eosinophilia, reduction of exacerbation episodes, along with major imb 'vement in clinical symptoms (15). Patients on anti-IL-5 therapies experienced approxı. $n$; ely half of the asthma exacerbation rates (88). However, improvements in health-re ted quality of life (HRQoL) scores and lung function could not be confirmed due to ins f $^{\dagger} \kappa^{\text {innt }}$ evidence (88). With regards to safety, patients taking reslizumab, mepolizumal on henralizuamb did not experience any serious adverse effects (88). Moreover, novel i. arapies targeting other eosinophil-associated factors and their receptors have also been tuded, including those that target CC-chemokine receptor 3 (CCR3), prostaglandin I'2 ( 'GD2), thymic stromal lymphopoietin (TSLP), as well as novel oligonucleotide therapies.

\subsubsection{Reslizumab}

Reslizumab is a humanized, neutralizing anti-IL-5 monoclonal antibody which acts by binding to IL-5 to block its interaction with its receptor $(89,90)$. IL-5 receptors (IL-5R) can be found on the surfaces of eosinophils. IL-5 functions to increase the activation and maintenance of eosinophils, which drives eosinophilic inflammation (89). As such, the blocking of IL-5 binding with its receptor on eosinophils leads to the disruption of eosinophil maturation and promotes apoptosis (91). Many studies have shown the beneficial outcomes from reslizumab treatment in patients with severe eosinophilic asthma. For example, in an 
experiment comparing reslizumab and placebo use in asthma patients, the reslizumab group experienced significantly less asthma exacerbations as compared to the placebo group (91). The results of the study concluded that reslizumab can be effectively used for treating asthma patients with persistent eosinophilia who are inadequately controlled with corticosteroids (91). Another study reported that patients that were administered $3.0 \mathrm{mg} / \mathrm{kg}$ of IV reslizumab every month experienced better asthma control as well as an improved lung function (90). The study also highlighted that patients with an increased eosinophil load that is inadequately managed with moderate-high doses of ICS benefited the most from reslizumab therapy (90). When compared to benralizumab, which targets IL-5R $\alpha$, it was shown that reslizumab confers higher efficacy than benralizumab in patients with eosirı ${ }_{\mathbf{r}}$ hilic asthma (89).

\subsubsection{Mepolizumab}

Another anti-IL-5 monoclonal antibody with the same mechanism of action as reslizumab is mepolizumab, which has shown to be $u_{s} f_{A} \cdot$ for treating eosinophilic asthma in several studies. In a research carried out by $\mathrm{Hal}_{\text {a }} \rho t$ al., the efficacy of mepolizumab in the treatment of patients with refractory ec nopnilic asthma and history of recurrent exacerbations was investigated. who $\mathrm{h}$ `rf administered mepolizumab therapy for 1 year experienced reductions in exacerbatic n rates as well as improvements in the Asthma Quality of Life Questionnaire (AQLQ) sc $\mathrm{r}^{\prime}$ (92). At the end of the study, the patients who undergone 1 year of therapy repc ste.' less exacerbations, scored higher in the Asthma Quality of Life Questionnaire (AQLC, and showed significant reductions in levels of blood and sputum eosinophils (92). Hov ever, mepolizumab showed no significant distinction in symptoms, post- brencl odil itor $\mathrm{FEV}_{1}$, or airway hyperresponsiveness when compared to placebo and other anti-L-5 therapies (92). Another study demonstrated the effects of mepolizumab in prednisone-sparing. Nair et al., reported that mepolizumab administered to asthma patients with high sputum eosinophils despite continuous prednisone therapy effectively lowered blood and sputum eosinophil counts and thus, proved the prednisonesparing effect of mepolizumab (93). Furthermore, Sehmi et al., demonstrated that subcutaneous mepolizumab therapy significantly attenuated systemic differentiation of eosinophils in severe eosinophilic asthma patients, as observed from the decrease in blood eosinophils and elevated eosinophil-lineage-committed progenitors (EoP) counts in the mepolizumab group (94). However, mepolizumab had no significant effects on mature eosinophils, sputum EoP counts or maintenance dose of prednisone, indicating that mepolizumab did not inhibit differentiation of local airway eosinophils to mature cells (94). 
Thus, it is evident that airway eosinophilia and severe eosinophilic asthma can be optimally controlled by targeting IL-5 pathway-associated local airway eosinophil differentiation. In a comparison study on the effectiveness of anti-IL-5 therapies, mepolizumab showed superiority in reducing the frequency of asthma exacerbations and improving asthma control over reslizumab or benralizumab in severe eosinophilic asthma patients with identical baseline levels of blood eosinophils (95).

Despite these studies that showed a positive outcome from mepolizumab therapy, there exists some concerns regarding the potential risk of 'rebound' eosinophilia following treatment cessation (55). Another study has also showed that mepolizumab treatment cessation resulted in rapid blood eosinophilia and subsequent wu'sening of asthma symptoms and exacerbations (55). Thus, further studies should be car ied sut to ensure the safety of eosinophil-targeted therapies. Nonetheless, mepolizumab s ap roved by both FDA and EMA to be used in patients $>6$ years of age with severe eosin ${ }_{k}$ hilic asthma. The primary benefits of mepolizumab include improvements in the lung tun.ton (forced expiratory volume) and marked reductions in asthma exacerbations (96)

\subsubsection{Benralizumab}

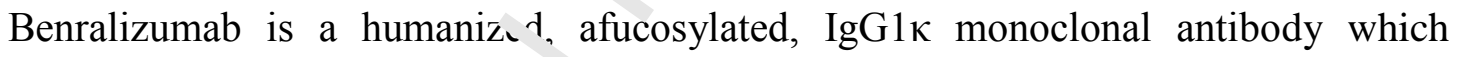
prevents the receptor interaction $0 . J_{L} 5$ by binding to IL-5R $\alpha$ via its Fab domain. As a result, eosinophilia is reduced i 1 b'nod, tissue and bone marrow due to the inhibition of eosinophil differentiation and i. aturation. In addition, benralizumab also depletes eosinophils in tissues and systemic cir vlalıon via antibody-dependent, cell-mediated cytotoxicity as it can bind to the RIII re rion of the Fc $\gamma$ receptor on NK cells, neutrophils and macrophages through its afucosylated ic domain $(97,98)$. The dual-function of benralizumab allows for a more rapid and sustained reduction of eosinophilia than other IL-5-targeted monoclonal antibodies (97). Benralizumab therapy has shown positive outcomes in both moderate-severe asthma patients as well as eosinophilic chronic obstructive pulmonary disorder (COPD) patients (99). Sridhar et al. conducted a research in which eosinophilic asthma and eosinophilic COPD patients were given benralizumab subcutaneously and the results demonstrated that benralizumab could selectively modulate eosinophil- and basophilassociated blood proteins and genes (99) Following benralizumab administration, eosinophil chemokines (eotaxin 1 and 2) were upregulated significantly in both the asthmatic and COPD patients (99). Furthermore, the expression of eosinophil- and basophil-associated genes were significantly reduced following benralizumab therapy (99). Thus, benralizumab is shown to 
selectively modulate blood proteins and eosinophil- or basophil-associated genes, with alterations occurring prominently in eosinophil-high patients rather than eosinophil-low patients (99). Randomized clinical trials have also provided evidence on the optimal safety profile of benralizumab, as well as its efficacy in reducing asthma exacerbations, steroidsparing and improvement of lung function (98). When compared to reslizumab, benralizumab was associated with a significantly improved lung function in asthma patients with severe eosinophilia ( $\geq 400$ cells $/ \mu \mathrm{L}$ ) (95). Benralizumab is approved by FDA as an add-on maintenance therapy for use in patients with severe eosinophilic asthma aged over 12 years. The primary benefits include significant reductions in the asthma exacerbations, improvements in lung function parameters (forced expiratory slume in one second) and marked reduction in prescription of inhaled corticosteroids (1 10$)$.

\subsubsection{Omalizumab}

Bronchial asthma is not only associated wil: sevations in pro-inflammatory Th2 cytokines, but also high levels of IgE. Besid's he roles of Th2 cytokines in eosinophil differentiation, maturation, migration, and suivival, they also contribute to the production of IgE. Omalizumab is an anti-IgE monoc $\urcorner n$ antibody that can effectively reduce peripheral blood eosinophil (PBE) counts as vell as airway eosinophil counts in asthmatic patients (101). Massanari et al., reported th 't ', nalizumab had an inhibitory effect on eosinophils as observed from the lowered PBE $\mathrm{Ou}^{\text {'ts }}$ in moderate-severe persistent allergic asthma patients who were on moderate-high - nses of ICS (102). It was observed that patients who were administered omalizumab hera y demonstrated a significant decrease in PBE counts from baseline, with patients tl at hive post-treatment free IgE levels $<50 \mathrm{ng} / \mathrm{mL}$ showing a larger decrease (102). In both steroid-reduction and steroid-stable phases of the studies, larger decreases in PBE counts were observed as compared to placebo (102). Thus, omalizumab treatment groups consistently experienced a pattern of lowered PBE counts and favourable clinical outcomes. Omalizumab is approved by both FDA and EMA to be used in patients over 12 years with moderate allergic asthma demonstrating raised levels of IgE. Omalizumab reduces the asthma exacerbation rates and, in some cases, reduces the corticosteroid prescriptions (103).

\subsubsection{Dupilumab}

Dupilumab is a novel anti-cytokine biologic drug used in the treatment of asthma. Therapies targeted at IL-4 and IL-13 are also beneficial in asthma treatments as they are Th2 
cytokines that can stimulate eosinophil recruitment and migration to local airways. IL-4 and IL-13 contributes to the pathophysiology of the typical characteristics of asthma, such as chronic airway inflammation, tissue remodeling and airway hyperresponsiveness (104). Dupilumab is a monoclonal antibody that can inhibit the interaction between IL-4 and IL-13 with IL-4R $\alpha$. In a recent study, dupilumab significantly attenuated Th2 cell-associated inflammatory biomarkers, which is correlated with an improvement in lung function and airway symptoms as well as reduction of asthma exacerbations in patients with difficult-tocontrol asthma (104). Dupilumab is approved to be used as an add-on therapy in patients over 12 years of age and who demonstrate a poorly controlled moderate-to-severe asthma phenotype. Dupilumab has been shown to prevent asthma exactriations and improvements in lung function (105).

\subsubsection{MEDI-563}

In addition to the commonly used anti-IL-5 $4 . "$ s, MEDI-563 is a novel humanized anti-IL-5R $\alpha$ monoclonal antibody that has ree.1 developed with an enhanced effector function in the management of asthma (106). Kolbeck et al., reported that MEDI-563 caused both eosinophils and basophils to under ${ }_{0}$ intibody-dependent cellular cytotoxicity (ADCC) in vitro (107). MEDI-563 administe.ed to non-human primates also decreased peripheral blood and bone marrow eosinophil $\mathrm{cc}^{\text {ntt }}$ (107). Thus, this study suggests that the focus of anti-asthma biologic therapies s $10 \mathrm{u}^{\prime} \mathrm{\gamma}$ be shifted from the passive removal of IL-5 to the reduction of eosinophil and bas vohı counts via ADCC mechanism.

\subsubsection{Novel CCR3 rerep. or a ttagonist}

Agents which tar et eosinophil cell surface-structures, for example CC-chemokine receptor 3 (CCR3), have also showed efficacies in decreasing blood and tissue eosinophil levels (108). Ki19003 (4-[[5-(2,4-dichlorobenzylureido) pentyl][1- (chlorophenyl) ethyl] amino] butanoic acid) is a novel CCR3 antagonist. CC-chemokine ligands (CCL), such as CCL11, CCL24 and CCL26, are associated with eosinophil chemotaxis (109). A study done by Komai et al., administered Ki19003 to ovalbumin-induced BALB/c mice to study its effects on airway remodeling in a mouse model of allergic asthma (109). It was observed that Ki19003 inhibited antigen-induced elevations in the number of eosinophils found in bronchoalveolar lavage fluid (BALF), but other cells were not affected (109). Furthermore, a dose-dependent increase in TGF- $\beta 1$ production in BALF and hydroxyproline amount in lungs were observed following Ki19003 administration (109). Ki19003 treatment also 
resulted in the attenuation of allergen-induced subepithelial and peribronchial fibrosis (109). Hence, it can be concluded that CCR3 antagonism can prevent eosinophil airway infiltration as well as the progression of subepithelial and peribronchial fibrosis following an allergen challenge. Therefore, the process of airway remodeling, which is a prominent feature of allergic asthma, can potentially be prevented using CCR3-targeted treatments.

\subsubsection{PGD2 antagonist}

Chemoattractant receptor-homologous molecules expressed on T-helper type 2 cells (CRTH2) that mediates chemotactic response to PGD2 are also expressed on eosinophils (110). PGD2 inhibitors, such as timapiprant and fevipiprant, : ave been studied for their effects on eosinophilia. Timapiprant was shown to impro e cr nditions of mild-moderate eosinophil-mediated allergic asthma patients whereas the administration of fevipiprant therapy to patients with moderate-severe asthma who wers not adequately managed with ICS resulted in reduced sputum eosinophil counts and su- ${ }^{-}$-quently, attenuation of eosinophilic airway inflammation (111). However, the phas 1.i trial of fevipiprant did not show marked clinical improvements in patients with poorly ontrolled asthma (112).

\subsubsection{Anti-TSLP}

TSLP plays a part in eosins pr : $^{1}$ is inflammation by recruiting eosinophils following epithelial damage. AMG 157 is a inman anti-TSLP monoclonal IgG2 $\lambda$ which inhibits the interaction and binding of T: $\mathrm{T}$ P to its receptor. A Phase I clinical trial conducted by Gauvreau et al., reported th 't A MG 157 treatment administered to allergic asthma patients of mild severity signifirant y r $\mathrm{r}$ duced FeNO in addition to blood and sputum eosinophil levels following and prior to alı rgen (113). Moreover, the AMG 157 treatment group experienced a greater reduction in maximum percentage decrease in $\mathrm{FEV}_{1}$ during late response than the placebo group, with a greater reduction occurring as the treatment progressed (113). Thus, the researchers concluded that AMG 157 attenuates bronchoconstriction and other indications of respiratory inflammation pre- and post-allergen challenge.

\subsubsection{Novel oligonucleotide therapy}

Oligonucleotides, such as siRNA and miRNA, are promising novel therapeutic strategies for the treatment of various respiratory disorders via their gene silencing or RNA interference abilities (114-117). An oligonucleotide-based therapy, TPI ASM8, was studied for its potential beneficial effects in lung function and sputum eosinophilia in patients with 
mild allergic asthma. TPI ASM8 consists of two phosphorothioate antisense oligonucleotides $(\mathrm{AON})$ which are modified, with one targeting CCR3 receptor and another targeting the beta chain $(\beta c)$ which is common among IL-3, IL-5 and GM-CSF receptors. According to a study carried out by Imaoka et al., patients with mild allergic asthma who were administered nebulized TPI ASM8 following an allergen challenge showed reductions in sputum eosinophils, early and late asthmatic responses, as well as airway eosinophil progenitor cells (118). Thus, it was concluded that the accumulation of eosinophils and their progenitor cells in airways of asthmatics can be inhibited successfully via TPI ASM8-mediated CCR3 and $\beta \mathrm{c}$ expression blockade. Therefore, further efforts of developing novel therapies that inhibit accumulation of airway progenitor cells should be taken.

\subsubsection{Corticosteroids}

Oral corticosteroids (OCS) are one of the mainstay therapies for the long-term management of severe asthma, which is characterize ' ' $\mathrm{y}$ persistent asthma symptoms and airway inflammation despite maximum efforts $\Lambda S^{1} .1^{\sigma}$, anti-asthma treatments. Corticosteroids effectively acts on various components of ti: $1 \mathrm{n} 2$ inflammatory pathway and its use can result in rapid attenuation of eosinop ils associated inflammation as well as long-term reduction in airway hyperresponsi ‘ness (119). As such, corticosteroids confer better responses in asthma patients with ecs:nophilic inflammation as compared to neutrophilic inflammation (120). However, a maj ,r drawback to corticosteroid use is the development of corticosteroid resistance or is sensitivity, which frequently occurs in long-term use of corticosteroids. This featur is $\epsilon$ specially prominent in severe asthmatics with persistent $\mathrm{Th} 2$ inflammation despite 1 gul ur OCS use. Thus, biological therapies are introduced as alternative therapies althe igh a large proportion of asthmatic patients will still require the use of OCS to control their asthma (119). The therapeutic action of OCS on inflammatory cytokines and eosinophils are proven in several studies. In a study conducted by Dente et al., short-term courses of OCS reduced both sputum eosinophilia and sputum pro-inflammatory cytokine concentrations, in addition to improving lung function in patients with severe refractory asthma (121). The improvement of pulmonary function was concluded from the significant increase in $\mathrm{FEV}_{1}$ following OCS treatment/ The prednisone group also exhibited a significant decrease in sputum eosinophil percentages and concentrations of IL-5 and IL-8 (121). It was also noted that prednisone treatment only showed positive effects in patients with baseline sputum eosinophilia, whereas only a significant decrease of sputum IL-8 was observed in non-eosinophilic patients (121). Several studies also reported on the inverse 
relationship between CS dose and PBE counts displayed in severe eosinophilic asthma patients. Prazma et al., predicted a model in which reducing the daily dose of OCS by 5 $\mathrm{mg} /$ day resulted in a $41 \%$ increase in PBE counts (122). Another study reported that ICS dose increment from medium to high dose in patients with uncontrolled asthma resulted in a significant reduction of blood eosinophil concentrations (123).

\subsection{Alternative therapies affecting eosinophils in the treatment of asthma}

\subsubsection{Quercetin}

Known to be present as flavonoids in fruits and vegetabic quercetin was shown to be an anti-inflammatory agent with the potential use in the tre tment of asthma (124). In this case, the clinical features of asthma were relieved by sup ressing the activation of the signaling pathway of $\mathrm{NF}-\mathrm{kB}$ which results in the redic 2 production of proinflammatory mediators associated with airway hyperresponsivenes ..ld airway inflammation (124). Two other studies have also insinuated quercetin's ' $v^{\prime}$, in the prevention of eosinophilic airway inflammation via the attenuation of eosinc hil activation, particularly the production of chemokines $(125,126)$. In the study by 'he $\mathrm{k}$ Yong et al., quercetin was encapsulated into a lipid crystalline nanoparticle (LCN) ^overcome its limitation in terms of bioavailability as well as aqueous solubility which $\mathrm{r}_{\mathrm{su}}$ - 2 in in the successful exhibition of an improved antiinflammatory effect of quercetin whin tormulated as such (124).

\subsubsection{Curcumin}

Curcumin is a cc nstil lent originating from the spice, turmeric, that is thought to be a potential remedy for the 1 lanagement of asthma $(127,128)$. Similarly, to quercetin, curcumin possesses anti-inflammatory properties which relieve airway inflammation of allergic nature as well as airway hyperresponsiveness through the suppression of the activation of the signaling pathway associated with NF- $\mathrm{BB}$ and the attenuation of eosinophil production (128). Its clinical application is also limited by the same reasons seen in quercetin $(128,129)$. Hence, $\mathrm{Ng}$ et al., sought to load curcumin into liposomes as liposomes were noted to be able to modify a system's pharmacokinetic and biodistribution profiles (128-130). The study managed to overcome the limitation of curcumin's unfavourable solubility as well as demonstrate the sustained release properties attained through the encapsulation of curcumin in a liposome, indicating that curcumin loaded liposomes could be an appealing option for the treatment of asthma (128). 


\subsection{Eosinophils and COPD}

Chronic obstructive pulmonary disease is described by the Global Initiative for Chronic Obstructive Lung Disease (GOLD) as a disease that can be commonly prevented and treated (131-134). However, COPD is noted to be among the most substantial causes of morbidity and mortality globally and this has caused a significant burden which is ever growing on the economy and society (131). This disease is characterized by the poorly reversible limitation of airflow which is commonly progressive and the elevated response to chronic inflammation that occurs in the peripheral airways anc "'ng parenchyma due to the inhalation of noxious particles or gasses which is primarily but not exclusively) caused by smoking tobacco (131,135-137). Emphysema and small . irw; y fibrosis may result from the chronic inflammation because of the destruction of nat nchymal tissue and disruption of mechanisms of repair and defense which causes the sise of the characteristic symptoms associated with COPD $(131,135)$. As the cistase progresses, so does the degree of inflammation which results in the elevation of neutrophil, macrophage and lymphocyte levels within the airway lumen (137). The $i_{1}, r_{f}$ dse in numbers of neutrophil and macrophages occur due to the activation of patt "n recognition receptors which precipitates an innate immune response that also gives rise in the activation of airway epithelial cells as well as mucus secretion $(137,138)$. An i icl ase in T lymphocyte and B lymphocyte numbers in the lungs is seen when adaptive i. 'munity is activated in the latter course of the disease which might result in the amplific tior of neutrophilic inflammation due to the increment in CD4+ Thelper 17 cells prese it is the lungs (137). Although various inflammatory cells are implicated in COPD, ne trophils are by far the most abundant and has been extensively associated with the pathogenesis of COPD (139-143). However, it has been reported that some COPD patients without asthma have elevated numbers of eosinophils in their airways instead during exacerbations and clinical stability (Figure 3) $(137,141,144,145)$. This is commonly seen in asthmatic patients where eosinophilic inflammation is known to be a distinguishing feature of the disease but the presence of a subdivision of COPD patients with eosinophilic airway inflammation has been reported (141,143,144,146-148). COPD patients with this phenotype are known to show the most significant response to corticosteroid treatment as well as an increased risk of exacerbation relapse and hospital readmissions $(140,142,143,146,149,150)$.

\subsection{Eosinophils and COPD}




\subsection{Role of eosinophils as biomarkers in COPD}

Blood eosinophils have been recognised by several studies to be potential a biomarker of disease severity and clinical outcome in exacerbations of COPD (151-153). The measurement of eosinophils present in the blood, as a proxy for eosinophils present in tissues, has become an essential biomarker for the prediction of risk of exacerbations in COPD patients (154). Elevated counts of blood eosinophil in COPD has been well associated to the clinical features of the disease. Patients with an increment in blood eosinophil levels of $\geq 450$ cells/ $\mu$ l during stable disease reportedly reflected a higher rate of exacerbation by $13 \%$ in the following year compared to patients with lower numbers (152). Another studied showed, amid COPD patients in the general population, increment G1 hlood eosinophil counts > $0.34 \times 10^{9}$ cells/L were affiliated with a heightened risk of ( eve oping severe exacerbations by 1.76-fold (155). However, blood eosinophils singularl ' w w re not a dependable biomarker to predict the severity of the disease, the associatar isk of exacerbations, or sputum eosinophilia (156). Instead, elevated sputum eosin. n- ${ }^{\mathfrak{l}} \mathrm{ll}$ counts acts as a more reliable biomarker compared to elevated concentrations of blood eosinophils for the identification of a subdivision of patients with more disease se erity and more persistent exacerbations (156).

Eosinophil concentrations may $a^{-} \mathrm{o}$ be a useful biomarker for the prediction of outcomes in COPD as increased nut. her of blood eosinophil in COPD were related with a longer survival period and a highe isidence of hospital readmissions (157-159). A study also suggested that the deterioration th pulmonary function tests could be predicted according to number of blood eosinoph:' (1د8). Low blood eosinophil counts on the other hand, is predictive of a poorer clinic 1 ol icome and longer durations of hospital admission (158-160). However, a few studies rep rt that blood eosinophil counts do not appear to be related to mortality $(158,161)$. It is lso noted that blood eosinophil concentrations can be utilized as a biomarker for the prediction of readmissions of patients suffering from severe COPD exacerbations (162). Moreover, Bélanger et al., suggests a relationship between greater blood eosinophil count upon admission of a COPD exacerbation and increased rate of readmissions (161-163).

\subsection{Eosinophils as a guide for COPD treatment}

Although airway eosinophilic inflammation in COPD may worsen the stabilization of symptoms, it can be used as to predict the benefit of treatment involving inhaled and oral corticosteroid $(157,163,164)$. A review by Hillas et al., states the benefit of corticosteroid use in patients experiencing acute exacerbation of COPD (AECOPD) who have increased blood 
eosinophils counts (165). The review also covered a post hoc analysis of three randomized controlled trials (RCTs) which demonstrated that COPD patients with eosinophil counts > 100 cells had a reduced risk of AECOPD of $25 \%$ when a combination of budesonide and formoterol was used compared to formoterol alone $(165,166)$. Two other studies also showed results of greater decrease of exacerbation frequency in patients as the blood eosinophil count increased when inhaled corticosteroids (ICS) was added to the therapy alongside a longacting $\beta$-agonist (LABA) whereas patients who were on a single therapy regimen of LABA exhibited progressively increasing rate of exacerbations as the eosinophil counts increased (165,167-169). In addition, Vestbo et al., has also demonstrated in his study that patients reflecting blood eosinophil counts $\geq 2 \%$ experienced reduced $c_{\lambda}{ }^{\top}$ cerbations of $30 \%$ with the use of either a regimen consisting of single inhaler extra fi ve to iple therapy or long-acting muscarinic antagonist (LAMA) (170). Likewise, the 201. G( LD COPD Strategy document states that blood eosinophil levels are to be used to mla ICS therapy in the treatment of stable COPD patients and frequent exacerbators as wt:" (71).

It was also suggested that ICS withdraw 11 . COPD patients with eosinophil counts $\geq$ $4 \%$ and a history of exacerbations may inc ease the possibility of developing AECOPD $(172,173)$. A trial reported that the $\mathrm{cu} \cdot \mathrm{tj}$ uous use of ICS reduced the exacerbations of moderate and severe grades in patie.. ${ }^{+}$s with either $\geq 4 \%$ relative eosinophil count or $\geq 300$ cells/mL absolute eosinophil count cr. $_{\text {. }}$ nared to patients who were tapered off ICS (173). Similarly, the SUNSET trial ider (1tr that as ICS was tapered off, it led to a heightened risk of exacerbations among patier. whin an eosinophil count of $\geq 300$ cells $/ \mathrm{mL}$ (174). However, several studies including tis - Cınical Practice Research Datalink (CPRD) reported that ICS withdrawal among COF $\supset$ pi tient did not affect the exacerbation risk of moderate-to-severe severity significantly $(1, ?, 175-177)$. The difference in findings might be due to the use of different patient groups where the WISDOM trial had made use of patients with COPD of high severity, a past medical history of exacerbations and prior treatment with ICS before the trial, the SUNSET trial studied COPD patients treated with ICS regimens long-term and did not have persistent exacerbations whereas other studies such as CPRD utilised a patient population not at high exacerbation risk where the usage of bronchodilators and ICS are lesser than clinical trials (172-174). Nevertheless, both the WISDOM trial and CPRD reported a similar finding whereby patients with eosinophil counts more than $6.0 \%$ do not have an increased risk of exacerbations on withdrawal of ICS $(172,173)$.

The study by Oshagbemi et al., did not report findings of increased all-cause mortality risk among patients with elevated absolute or relative blood eosinophil counts who withdrew 
from ICS regimen but there are several studies that have evidence which conflict this finding $(172,178,179)$.

Even though, blood eosinophil counts can be regarded as a guide to treating COPD, it is critical to remember that COPD patients, blood eosinophils are not influenced by ICS use $(165,180)$. This is because there is pronounced variation in blood eosinophil levels $(165,181-$ 183). Hence, one measurement of blood eosinophil counts may not be sufficient for the accurate choice of utilizing ICS in a COPD patient's regimen (165).

\subsection{Therapeutic targets for eosinophilic inflammation in COPD}

COPD treatment regimens are largely associated with use of bronchodilators which treat the symptoms but not the underlying inflamı atic n nor disease progression (135). Biologics targeting immune mediators such as IL -5 ar showing promising results in COPD patients with the eosinophilic phenotype $(135,10 \cdot 1)$ IL-5, a key eosinophil cytokine mediates its differentiation, proliferation, survival, anı' - - tivation via the IL-5 receptor (184187). Humanized monoclonal antibodies, mepo' $1 \mathrm{Z}^{\prime}, \mathrm{mab}$ and benralizumab reduces blood and tissue eosinophil counts via the inhibition of : -5 vinding to eosinophil surface receptors and binding to interleukin-5 receptor $\alpha$ res ${ }^{~} \mathrm{c}^{+}{ }^{+}$vely $(185,186,188-190)$. These two drugs have been known to successfully reduce $\epsilon$-sinophilic inflammation and lower exacerbations rates in asthma (135). However, mepoliz ar ${ }^{\text {h }}$ was not able to obtain the approval from the US Food and Drug Administration $\left(\mathbf{L}^{\prime}\right)$ to be used as an adjuvant to the maintenance regimen for COPD patients with eosi. pphıiic inflammation because one of two phase III studies carried out showed no evid nce of efficacy $(135,184,186,187)$. Studies on benralizumab have been inconsistent in whi $\mathrm{h}$ il demonstrated a decrease in rate of exacerbations in a Phase IIa trial consisting of $\mathrm{COP} \mathrm{L}$ patients with eosinophilic inflammation but failed to reach the primary end point in two phase III trials consisting of COPD patients with exacerbation histories of moderate to very severe grades $(135,185,189,190)$.

Another target of interest in eosinophilic COPD is the transcription factor, GATA3 which plays a part in the activation of Th2 cells and action on the type 2 innate lymphoid cells (ILC2 cells) (191). These interactions result in increased cytokine IL-4, IL-5 and IL-13 production which are thought to moderate airway eosinophilia in non-allergic asthma and COPD (191). SB010 is a drug that consists of the active constituent, DNAzyme hgd40 which specifically binds to and cleaves the mRNA of GATA3 and has been evaluated in human and animal models (191). Turowska et al., reports significantly reduced GATA3 mRNA along with reduction of Th2-specific cytokines production in murine models of allergic airway 
inflammation when treated with SB010 (192). Greulich et al., were able to prove the involvement of the GATA3 pathway in eosinophilic COPD patients through their phase IIa clinical trial which sought to demonstrate the feasibility to reduce sputum eosinophilia in COPD patients with elevated sputum eosinophil counts through treatment involving the inhalation of GATA3-specific DNAzyme SB010 for 4 weeks and were able to conclude that a decrease in airway eosinophilia is possible to attain via the GATA3-specific DNAzyme as such seen previously in asthmatic patients (191). Furthermore, the trial was able to identify the safety aspects associated with the use of SB010 in the studied COPD population whereby serious adverse events were not reported (191). However, the trial only included a small patient group so more studies including a larger patient groups and longer treatment period will be required for the identification of the long-term clinica' eft :ctiveness and safety in this subgroup of COPD patients (191).

\subsection{Eosinophils and Cystic Fibrosis}

Cystic fibrosis is an autosomal re essive disorder that is an illness which is chronically progressive and life-limiti.s (193-196). The disease occurs due to a gene mutation of CF transmembrane cinductance regulator (CFTR) causing a significant functional deficiency in the CFTR or, : in which are highly expressed in the tissues of the airways (193-195). In normal (Irc-mstances, the CFTR protein functions to regulate the movement of chloride and soc. Im ions across the epithelial cell membranes but when either one or both copies of the $\xi^{\text {ane }}$ is mutated, transport of the ions is deficient, resulting in the accumulation of thick 1 uce $;$ throughout the body which can lead to the development of respiratory insufficiency. consequential deficiencies in host anti-bacterial defences and various other systemic obstructions and abnormalities (193-195). Including being a chronically progressive lung illness, cystic fibrosis is also characterised by extensive inflammation and respiratory failure (195). This could be further exacerbated by the formation of biofilms on the exterior of medical appliances utilized for treatment causing lifethreatening infections in these patients (197). Cystic fibrosis is known to affect multiple organs and the common symptoms include breathlessness or wheeze, persistent cough along with frequent respiratory infections, increased appetite and bulky greasy stools (198). Deterioration in pulmonary symptoms and the loss of lung function are the key factors that determine the severity of cystic fibrosis. More than half of the patients may require a lung transplantation during severe form of the disease (199). 
Cystic fibrosis associated inflammation is known to be dominated by neutrophils which releases oxidants and proteases such as elastase which can be found in airway secretions preceding the development of bronchiectasis in these patients $(194,195,200,201)$. A few studies have also reported of the correlation between neutrophil elastase with the deterioration of lung function as well as respiratory exacerbations (194,200). However, Zhang et al., notes that a type II inflammation associated with an asthma phenotype can often be recognised in cystic fibrosis patients (195). The presence of this type of inflammation is indicated by the increased levels of total immunoglobulin $\mathrm{E}(\mathrm{IgE})$, specific $\operatorname{IgE}$ sensitization or absolute eosinophil count in the circulation independent vi infection by the pathogen, Pseudomonas aeruginosa $(195,202)$. This enables the differe tiat on of the similar symptoms of asthma and cystic fibrosis in terms of variability of lun f function and bronchodilator response which in turn aids the recovery of lung functi $\eta$, airway remodeling, and rate of exacerbations in patients with eosinophilic inflamma an $^{-1}$ related exacerbations through the focus of treatment on to the type II inflammat or; response (195). Moreover, the study by Zhang et al., showed positive effects via a c crease in eosinophil and IgE levels as well as dose of corticosteroids when mepolizun ${ }^{-h}$ was used to treat type II inflammation in patients with eosinophilic phenotype cystic fii "osis (195).

Apart from neutrophils taat are known to play an important inflammatory role in airway disease associated wit. cysic fibrosis, eosinophils are also found to be one of the components that contribute to i jury during cystic fibrosis. In two separate studies involving 42 and 20 patients with 'ystı : fibrosis respectively, Koller et al., showed significantly higher levels of ECP in sputu, 1 of patients with cystic fibrosis compared to control subjects $(203,204)$. Collectively, these findings indicated the destructive role played by eosinophils and an interrelationship between the clinical variables and secretory activity of eosinophils in cystic fibrosis. An increase in the propensity of eosinophils to release their granule proteins and a firm correlation between ECP levels and variables of pulmonary function like forced vital capacity has also been identified $(204,205)$. Furthermore, cytokine profiles were found to be responsible for eosinophil activation and degranulation in patients with cystic fibrosis, especially IL- 8 and IL-3 were found to be significantly correlated with the levels of ECP in sputa from 32 patients and therefore, these appeared to be responsible for elevated degranulation of eosinophils (206). 
However, the mainstay drugs used to treat cystic fibrosis have been noted to cause various side effects (207). Thus, in order to diminish these drug associated side effects experienced by patients, tissue targeting strategies should be utilized to overcome the inadequate drug penetration due to the barrier formed by the accumulation of thick and viscous mucus $(208,209)$.

\subsection{Eosinophils and Pneumonia}

Pneumonia is a disease which is relatively prev len and has caused a significant burden towards the global population (210). It is definec by the acute infection of the lung parenchyma and is used as a hypernym to describe a “ "'ster of syndromes caused by not one disease but a group of specific infections, $v a \mathrm{l}, \mathrm{h}$ result in different manifestations and sequelae (210,211). Acute and chronic eosin thilic pneumonia are two common pulmonary eosinophilic disorders which occur du $+\boldsymbol{J}$ lung tissue damage by activated eosinophils $(212,213)$. These disorders are characterized by the build-up of eosinophilic infiltrates in the pulmonary parenchyma, often acco nr « nied by peripheral blood eosinophilia, which can be caused by either infectious or nor $-1{ }^{{ }^{c}}{ }^{{ }_{e}}$ ctious factors $(212,214)$.

De Giacomi et al., repu ts significantly elevated levels of IL-33 in acute eosinophilic pneumonia (AEP) patients $\therefore$ nd rypothesized that IL-33 plays an essential role in AEP (213). This is because attracti $n$ a id activation of eosinophils is amplified when Th2-polarizing cytokines, IL-5 and IL-1 _ are rapidly produced due to the robust production of IL-33 as well as the enlistment and activation of ILC2 cells in the mucosa of the airway which takes place due to either epithelial or endothelial cell (213). However, the study by Katoh et. al. reports that IL-33 levels were not considerably elevated in the bronchial alveolar lavage fluid (BALF) of eosinophilic pneumonia patients whereas IL-25 and IL-5 levels were significantly heightened in the BALF of chronic eosinophilic pneumonia (CEP) patients but not AEP patients (215). Hence, it was postulated that CEP might be perpetuated by IL-25 which were thought to be produced by eosinophils via IL-5 stimulation $(215,216)$. Despite these reports, the pathophysiology of both AEP and CEP are poorly understood and will require further studies to completely delineate it $(213,214)$. 
Treatment of AEP and CEP both utilize corticosteroids as the mainstays of treatment in which AEP is treated with systemic corticosteroids whereas CEP utilizes oral corticosteroid therapy with an aim to diminish the disease progression as well as lessen the risk of relapse (212-214,217-219). As an alternative therapy for CEP, biologic agents have been utilized for the regulation of eosinophilic inflammation $(218,219)$. Studies have shown the effectiveness of omalizumab, an anti-IgE antibody and anti-IL-5 antibody's, mepolizumab and reslizumab in the treatment of CEP through the reduction or discontinuation of corticosteroid use in patients with relapsed CEP $(218,219)$. IL-5 is a common aim in the treatment of CEP because its elevated levels are associated with the release of cytotoxic granular proteins from eosinophils which is $r$ sstulated to be an important underlying mechanism of CEP (219). However, there is ins 'ffic ent information supporting the utilization of biologics for CEP treatment as well a the concerns associated with the adaptation and treatment duration of it $(218,219)$. Henne, firther studies regarding the use of steroid-sparing therapeutic regimens as an alternative ${ }^{n}{ }^{-}$apy for CEP are required.

\subsection{Eosinophils and Lung Cancer}

Lung cancer is a common malig anc y anong both sexes and represents over $10 \%$ of all malignancies $(220,221)$. The occun nce of eosinophilia is often attributed to hematological malignancies, with $=>\mathrm{m}$ cases of solid tumour-associated eosinophilia. Approximately $1 \%$ of malignant $\operatorname{r} \mathrm{In}$ - ars are associated eosinophilia (220). Bone marrow stimulation by IL-5 is theorized in be the primary causative factor of solid malignancyassociated eosinophilia. Para eoplastic eosinophilia cannot be treated with a specific treatment, besides treat ilg the underlying malignancy using typical therapies, including surgery, chemotherapy, : эaıtherapy, or even novel treatments such as metformin (222).

\subsection{Function of eosinophils in the pathophysiology of lung cancer}

A distinct feature of cancer is sustained low-grade inflammation. Eosinophils have long been associated with cancer as they are one of the regulatory components of the tumour microenvironment (TME) responsible for tumour initiation and development (223). Eosinophils are commonly associated with negative connotations in allergic diseases, however they are able to provide immune protection against helminths, bacterial and viral pathogens (223).

There are evidences showing that the infiltration of eosinophils into tumour cells results in an improved prognosis of cancer (224). Tumour-associated eosinophilia can be 
observed in many studies of patients with cancer as well as mouse models of cancer. Studies have reported that activated eosinophils play a vital role in tumour rejection. Activated tumour-honing eosinophils release chemoattractants which induces the migration of tumourspecific CD8(+) T-cells into the tumour, resulting in tumour eradication and thus, an increased chance of survival (225). Tumour rejection is also promoted by the significant alterations in the tumour microenvironment as initiated by the activated eosinophils, such as macrophage polarization and normalization of tumour vasculature (225).

Eosinophil peroxidase (EPO), which is an eosinophilic cationic granule protein, drives cell cycle progression and proliferation at non-cytotoxic levels, thus suggesting the role of eosinophils in tumorigenesis (226). According to a stuay conducted by Walsh et al., EPO increased the expression and phosphorylation of epider ' al s rowth factor-2 (HER2) in a sustained manner, which consequently induced extracell lar- egulated kinase 1/2 activation (226). Subsequently, cyclin-dependent kinase inhibitor $n<7$ (kip) entered the cytoplasm from the nucleus in a focal adhesion kinase-dependent man. ${ }^{-}$. Thus, the findings of the study led to the conclusion that EPO can induce the 1 pr sulation of cell proliferation via HER2 mediation.

However, the actions of eosinop ils $_{\mathrm{s}}$ and eosinophil mediators varies according to the cancer type as eosinophils have beeı linked to improved prognosis in certain neoplasias but poor prognosis in others. This is tera'se eosinophils can produce either anti-tumorigenic (e.g. TNF- $\alpha$, IL-18, granzyme, an $d$ `^t1onic proteins) or pro-tumorigenic molecules (e.g. proangiogenetic factors) subject o the internal environment (223). Melanoma, oral, gastric, colorectal, and prostate cai ers are neoplasias in which eosinophils secrete anti-tumorigenic factors whereas a pnor pro nosis is expected from the actions of eosinophils in cervical carcinoma and Hodgkin's lymphoma (223).

Although there exist evidences for a positive correlation between eosinophils and better responses in some patients with melanoma, investigations to study the relationship between eosinophils and NSCLC are not frequently conducted. However, a case report showed that a patient with metastatic lung adenocarcinoma (AD), a type of non-small cell lung cancer (NSCLC), presented with shortness of breath, chest pain and associated hypereosinophilia, as defined by an absolute eosinophil count (AEC) of $>1500$ cells $/ / \mu \mathrm{L}$, in the absence of primary bone marrow disorder (220). Additionally, a study done by Lou et al., reported that a patient with metastatic lung $\mathrm{AD}$ presented with asymptomatic hypereosinophilia following initiation of nivolumab therapy, which is an anti-programmed cell death 1 (PD-1) drug (227). Following a transient discontinuation of therapy, her 
eosinophil counts transiently decreased, but increased again following re-initiation. The patient showed a favourable response throughout the therapy. Thus, eosinophils can act as potential peripheral biomarkers of favourable response to immunotherapy in patients with lung carcinoma, which warrants further studies of the role of eosinophils in lung carcinoma for the development of novel treatment strategies. As such, efforts should be focused on the delivery of eosinophil-targeting drugs for lung cancer in the form of nanocarriers in order to improve specificity and reduce adverse effects $(228,229)$.

\subsection{Eosinophils as biomarkers of lung cancer}

Eosinophils can be used as a peripheral blood marker for tetecting tumour-associated protein expression in cancer patients. Tumours cells in pri nar lung AD express surface immune factors such as indoleamine-2,3-dioxygenase-1 ( DO ) and programmed cell deathligand-2 (PD-L2) (230). A study showed that AEC alng with absolute monocyte count

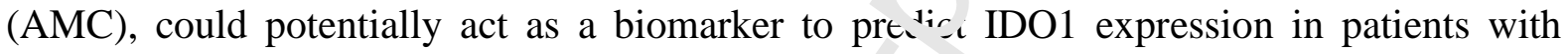
resected stage 1 to 3 primary lung AD (230). Jग,1 is a tryptophan (Trp) catabolic enzyme that catalyzes the transformation of Trp to ky. 'Irenıne for immunosuppressive functions such as activation of myeloid-derived suppres $\mathfrak{n} r$ cells and T-regulatory cells, inhibition of effector T and NK cell functions, and promoti $n$ of neovascularization of solid tumours (231).

Eosinophils can also act as cinical outcome predictors in patients with lung AD.

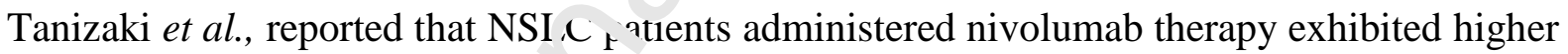
AECs which were significantl, linked to a better progression-free and overall survival (232). Additionally, a cohort stud rep urted that elevated eosinophil counts correlated with reduced mortality risk in specific sub; roups of cancer patients, such as colorectal cancer (233).

However, a study showed that only a small percentage of eosinophils $(0.3 \%)$ were present in the immune infiltrate composition of NSCLC tumours (234).

Besides AEC, another eosinophil-related biomarker of lung AD is EPO. Ye et al., demonstrated that EPO overexpression in lung AD patients can potentially act as a biomarker for poor prognosis (235). During the study, a significantly higher expression of EPO mRNA and protein in lung AD tissues as compared to adjacent normal tissues were observed (235). Moreover, patients with EPO overexpression were significantly associated with pathologictumour nodes metastases stage and lymph node metastasis, as well as decreased survival time as compared to patients with low levels of EPO (235). 


\subsection{Eosinophils and Acute Lung Injury}

Acute lung injury (ALI) describes clinical syndromes of acute respiratory failure with prominent mortality and morbidity rates (236). The management of ALI after exclusion of infection consists of primarily supportive measures. Other diagnoses can be ruled out by performing surgical lung biopsy, however this measure has proven to be less useful for predicting therapy methods and outcomes in ALI (237). Peripheral blood and tissue eosinophil counts are often referred to as hallmarks of steroid-responsive acute eosinophilic pneumonia, but are not typically associated with ALI (237). Thus, a study conducted by Willetts et al. demonstrated that eosinophil peroxidase-rer $\operatorname{og}_{\mathrm{L}}$ 'zing monoclonal antibody (EPX-mAb) immunohistochemistry can be used as a nethod to assess eosinophil accumulation or degranulation in the lungs of ALI patic. ts as well as predict the prognosis of survival (237). Therefore, it is suggested that Er X-n Ab immunohistochemistry can be utilized as a diagnostic biomarker to identify a nruportıun of ALI patients with favourable clinical outcomes.

Various clinical trials conducted targeting w ssinophils in respiratory diseases are shown in Tables 1-3 and various important ㄱop targeting eosinophils in respiratory diseases are $\begin{array}{llllll}\text { shown } & \text { in } & \text { Fig're } & \text { Table } & 4\end{array}$ 


\section{Conclusion}

Respiratory disorders are chronic conditions requiring long-term therapy to prevent clinical symptoms. Morbidity and mortality are high for many respiratory disorders and existing available treatments are restricted due to lack of effectiveness, severe toxicity or both. Recent efforts to understand eosinophil biology has opened the door to many innovative biological treatments. Various drugs that target eosinophils are currently being tested in clinical trials and needs to be validated prior to medical use. No health issues are raised till date, despite theoretical concerns about the possible toxicity of rapidly declining eosinophil counts and the long-term effects of eosinophil depletion on the immune system and tumor monitoring. We expect to gain a better understanding with more research to recu ${ }_{i}^{-n i z e}$ new biological factors for these respiratory disorders and eventually the implen enta ion of this knowledge to patients.

\section{References}

1. Ravin KA, Loy M. The Eosinophil in Inf $f_{0}$ J Jn. Clin Rev Allergy Immunol. 2016 Apr;50(2):214-27.

2. Stone KD, Prussin C, Metcalfe D' ' I ${ }_{2}$ E, Mast Cells, Basophils, and Eosinophils. J Allergy Clin Immunol. 2010 Feb;12s? Suppl 2):S73-80.

3. Blanchard C, Rothenberg ME Iiolugy of the Eosinophil. Adv Immunol. 2009;101:81121.

4. Fulkerson PC, Rothenbe g N.E. Targeting eosinophils in allergy, inflammation and beyond. Nat Rev Drug Disiov. 2013 Feb;12(2):117-29.

5. Mathur SK, Fichti tge ' between allerg, $7 \boldsymbol{1}^{\mathrm{N}} \mathrm{ir}$ nate immunity: Model for eosinophil regulation of epithelial cell interferon expressı n. Ann Allergy Asthma Immunol Off Publ Am Coll Allergy Asthma Immunol. 2013 Jul;111(1):25-31.e1.

6. Wong TW, Doyle AD, Lee JJ, Jelinek DF. Eosinophils Regulate Peripheral B Cell Numbers in Both Mice and Humans. J Immunol. 2014 Apr 15;192(8):3548-58.

7. Akuthota P, Wang H, Weller PF. Eosinophils as Antigen-Presenting Cells in Allergic Upper Airway Disease. Curr Opin Allergy Clin Immunol. 2010 Feb;10(1):14-9.

8. Jacobsen EA, Zellner KR, Colbert D, Lee NA, Lee JJ. Eosinophils Regulate Dendritic Cells and Th2 Pulmonary Immune Responses following Allergen Provocation. J Immunol. 2011 Dec 1;187(11):6059-68.

9. Chu VT, Fröhlich A, Steinhauser G, Scheel T, Roch T, Fillatreau S, et al. Eosinophils are required for the maintenance of plasma cells in the bone marrow. Nat Immunol. 2011 Feb;12(2):151-9. 
10. Wu D, Molofsky AB, Liang H-E, Ricardo-Gonzalez RR, Jouihan HA, Bando JK, et al. Eosinophils sustain adipose alternatively activated macrophages associated with glucose homeostasis. Science. 2011 Apr 8;332(6026):243-7.

11. Kim H-J, Alonzo ES, Dorothee G, Pollard JW, Sant'Angelo DB. Selective Depletion of Eosinophils or Neutrophils in Mice Impacts the Efficiency of Apoptotic Cell Clearance in the Thymus. PLoS ONE [Internet]. 2010 Jul 6 [cited 2020 Jan 19];5(7). Available from: https://www.ncbi.nlm.nih.gov/pmc/articles/PMC2897847/

12. Wen T, Rothenberg ME. The Regulatory Function of Eosinophils. In: Myeloid Cells in Health and Disease [Internet]. John Wiley \& Sons, Ltd; 2017 [cited 2020 Jan 12]. p. 257-69. Available from:

https://onlinelibrary.wiley.com/doi/abs/10.1128/9781555819194.ch14

13. Spencer LA, Szela CT, Perez SAC, Kirchhoffer CL, Neves 'S, Radke AL, et al. Human eosinophils constitutively express multiple Th1, Th?, and immunoregulatory cytokines that are secreted rapidly and differentially I I_ukoc Biol. 2009 Jan;85(1):117-23.

14. Davoine F, Lacy P. Eosinophil Cytokines, Che noi ines, and Growth Factors: Emerging Roles in Immunity. Front Immunol $\mathrm{in}^{\text {te }}$.net]. 2014 [cited 2020 Jan 12];5. Available from: https://www.frontiersin.oro/a.ticles/10.3389/fimmu.2014.00570/full

15. Varricchi G, Bagnasco D, Borriello F, - ethic E, Canonica GW. Interleukin-5 pathway inhibition in the treatment of eosir $\mathrm{spr}$ lic ıspiratory disorders: evidence and unmet needs. Curr Opin Allergy Clin Imn ' 1ol. 2016 Apr;16(2):186-200.

16. Sastre B, Rodrigo-Muñoz JM, Gå -ia-Sanchez DA, Cañas JA, Del Pozo V. Eosinophils: Old Players in a $\mathrm{N}, \boldsymbol{N}$ Game. J Investig Allergol Clin Immunol. 2018;28(5):289-304.

17. Halwani R, Al-Muhsen ; Al-Jahdali H, Hamid Q. Role of transforming growth factor$\beta$ in airway remodeling 1 . asthma. Am J Respir Cell Mol Biol. 2011 Feb;44(2):127-33.

18. Rosenberg HF D er $\mathrm{L}$ D, Foster PS. Eosinophils: changing perspectives in health and disease. Nat Rev 'mııunol. 2013 Jan;13(1):9-22.

19. Liao W, Long H, Chang CC-C, Lu Q. The Eosinophil in Health and Disease: from Bench to Bedside and Back. Clin Rev Allergy Immunol. 2016 Apr 1;50(2):125-39.

20. Kiwamoto T, Kawasaki N, Paulson JC, Bochner BS. Siglec-8 as a drugable target to treat eosinophil and mast cell-associated conditions. Pharmacol Ther. 2012 Sep;135(3):327-36.

21. Kvarnhammar AM, Cardell LO. Pattern-recognition receptors in human eosinophils. Immunology. 2012;136(1):11-20.

22. Månsson A, Cardell L-O. Role of atopic status in Toll-like receptor (TLR)7- and TLR9-mediated activation of human eosinophils. J Leukoc Biol. 2009 Apr;85(4):71927. 
23. Johansson MW. Activation states of blood eosinophils in asthma. Clin Exp Allergy $\mathbf{J}$ Br Soc Allergy Clin Immunol. 2014 Apr;44(4):482-98.

24. Johansson MW, Mosher DF. Activation of beta1 integrins on blood eosinophils by Pselectin. Am J Respir Cell Mol Biol. 2011 Oct;45(4):889-97.

25. Radke AL, Reynolds LE, Melo RCN, Dvorak AM, Weller PF, Spencer LA. Mature human eosinophils express functional Notch ligands mediating eosinophil autocrine regulation. Blood. 2009 Mar 26;113(13):3092-101.

26. Acharya KR, Ackerman SJ. Eosinophil Granule Proteins: Form and Function. J Biol Chem. 2014 Jun 20;289(25):17406-15.

27. Shamri R, Xenakis JJ, Spencer LA. Eosinophils in innat immunity: an evolving story. Cell Tissue Res. 2011 Jan 1;343(1):57-83.

28. Linch SN, Kelly AM, Danielson ET, Pero R, Lee JJ, Gc'd ' A. Mouse Eosinophils Possess Potent Antibacterial Properties In Vivo. Inf 'ct 1 nmun. 2009 Nov;77(11):4976-82.

29. Muniz VS, Weller PF, Neves JS. Eosinophil $c_{1_{1}}$ 'sta loid granules: structure, function, and beyond. J Leukoc Biol. 2012 Aug;92(2):2 s1-c

30. Dua K, Malyla V, Singhvi G, Wadhwa ?, 2 shna RV, Shukla SD, et al. Increasing complexity and interactions of oxir'al re tress in chronic respiratory diseases: An emerging need for novel drug delı ${ }^{\circ} r_{y}$ systems. Chem Biol Interact. 2019 Feb 1;299:168-78.

31. Panagopoulos V, Zinonos I, I ¿a_h UA, Hay SJ, Liapis V, Zysk A, et al. Uncovering a new role for peroxidase enz:' $m \mathrm{c}$ a as drivers of angiogenesis. Int J Biochem Cell Biol. 2015 Nov;68:128-38.

32. Ochkur SI, Kim JD, Pru 'he oe CA, Colbert D, Moqbel R, Lacy P, et al. The Development of a Ser. iti $/$ e and Specific ELISA for Mouse Eosinophil Peroxidase: Assessment of Eo ino, hil Degranulation Ex Vivo and in Models of Human Disease. J Immunol Metho'c. Zúl2 Jan 31;375(1-2):138-47.

33. Puxeddu I, Berkman N, Nissim Ben Efraim AH, Davies DE, Ribatti D, Gleich GJ, et al. The role of eosinophil major basic protein in angiogenesis. Allergy. 2009 Mar;64(3):368-74.

34. Tsuda T, Maeda Y, Nishide M, Koyama S, Hayama Y, Nojima S, et al. Eosinophilderived neurotoxin enhances airway remodeling in eosinophilic chronic rhinosinusitis and correlates with disease severity. Int Immunol. 2019 Feb 6;31(1):33-40.

35. Yang D, Chen Q, Rosenberg HF, Rybak SM, Newton DL, Wang ZY, et al. Human Ribonuclease A Superfamily Members, Eosinophil-Derived Neurotoxin and Pancreatic Ribonuclease, Induce Dendritic Cell Maturation and Activation. J Immunol. 2004 Nov 15;173(10):6134-42. 
36. Domachowske JB, Dyer KD, Bonville CA, Rosenberg HF. Recombinant human eosinophil-derived neurotoxin/RNase 2 functions as an effective antiviral agent against respiratory syncytial virus. J Infect Dis. 1998 Jun;177(6):1458-64.

37. Rugeles MT, Trubey CM, Bedoya VI, Pinto LA, Oppenheim JJ, Rybak SM, et al. Ribonuclease is partly responsible for the HIV-1 inhibitory effect activated by HLA alloantigen recognition. AIDS Lond Engl. 2003 Mar 7;17(4):481-6.

38. Chua JC, Douglass JA, Gillman A, O'Hehir RE, Meeusen EN. Galectin-10, a potential biomarker of eosinophilic airway inflammation. PloS One. 2012;7(8):e42549.

39. Carmo LAS, Bonjour K, Ueki S, Neves JS, Liu L, Spencer LA, et al. CD63 is tightly associated with intracellular, secretory events chaperoning piecemeal degranulation and compound exocytosis in human eosinophils. J Leuk' c Biol. 2016;100(2):391-401.

40. Spencer LA, Bonjour K, Melo RCN, Weller PF. Eosin ph.' Secretion of GranuleDerived Cytokines. Front Immunol [Internet]. $2014 \mathrm{n}_{\mathrm{t}}{ }^{27}$ [cited $2020 \mathrm{Apr} 9$ ];5. Available from: https://www.ncbi.nlm.nih.gov/pmc, artic les/PMC4209865/

41. Wright BL, Ochkur SI, Olson NS, Shim KP, Ja _vi st.l EA, Rank MA, et al. Normalized serum eosinophil peroxidase levels are inversely correlated with esophageal eosinophilia in eosinophilic esonh. $\mathrm{git}$ is. Dis Esophagus [Internet]. 2018 Feb 1 [cited 2020 Apr 9];31(2). Available fr Ji 1: https://academic.oup.com/dote/article/2/2/uux139/4714780

42. Gleich GJ, Leiferman KM. The hy $y_{\uparrow}{ }^{\circ}$ eosinophilic syndromes: current concepts and treatments. Br J Haematol. 2009 May; 45(3):271-85.

43. Mejia R, Nutman TB. Evalua 10.1 nd differential diagnosis of marked, persistent eosinophilia. Semin Hemat:! 2?2 Apr;49(2):149-59.

44. Simon H-U, Rothenberg ME, Bochner BS, Weller PF, Wardlaw AJ, Wechsler ME, et al. Refining the definitic. of hypereosinophilic syndrome. J Allergy Clin Immunol. 2010 Jul;126(1):45-9.

45. Mejia R, Nutma. TL. Evaluation and differential diagnosis of marked, persistent eosinophilia. Semir Hematol. 2012 Apr;49(2):149-59.

46. McBrien CN, Menzies-Gow A. The Biology of Eosinophils and Their Role in Asthma. Front Med [Internet]. 2017 Jun 30 [cited 2020 Jan 19];4. Available from: https://www.ncbi.nlm.nih.gov/pmc/articles/PMC5491677/

47. Mehta M, Dhanjal DS, Paudel KR, Singh B, Gupta G, Rajeshkumar S, et al. Cellular signalling pathways mediating the pathogenesis of chronic inflammatory respiratory diseases: an update. Inflammopharmacology. 2020 Aug 1;28(4):795-817.

48. Chan Y, Ng SW, Chellappan DK, Madheswaran T, Zeeshan F, Kumar P, et al. Celastrol-loaded liquid crystalline nanoparticles as an anti-inflammatory intervention for the treatment of asthma. Int J Polym Mater Polym Biomater. 2020 May 31;0(0):110 . 
49. Dharmage SC, Perret JL, Custovic A. Epidemiology of Asthma in Children and Adults. Front Pediatr. 2019 Jun 18;7.

50. Matucci A, Maggi E, Vultaggio A. Eosinophils, the IL-5/IL-5R $\alpha$ axis, and the biologic effects of benralizumab in severe asthma. Respir Med. 2019 Dec;160:105819.

51. Carr TF, Zeki AA, Kraft M. Eosinophilic and Noneosinophilic Asthma. Am J Respir Crit Care Med. 2018 Jan 1;197(1):22-37.

52. Brussino L, Heffler E, Bucca C, Nicola S, Rolla G. Eosinophils Target Therapy for Severe Asthma: Critical Points. BioMed Res Int. 2018;2018:7582057.

53. Bakakos A, Loukides S, Bakakos P. Severe Eosinophilic Asthma. J Clin Med. 2019 Sep 2;8(9).

54. Kandikattu HK, Upparahalli Venkateshaiah S, Mishra '.. ¿ vnergy of Interleukin (IL)-5 and IL-18 in eosinophil mediated pathogenesis of allerg: $r$ seases. Cytokine Growth Factor Rev. 2019 Jun;47:83-98.

55. Varricchi G, Bagnasco D, Ferrando M, Puggior: 7 'assalacqua G, Canonica GW. Mepolizumab in the management of severe eo nor hilic asthma in adults: current evidence and practical experience. Ther Adv F.espi: Dis. 2017;11(1):40-5.

56. Beckert H, Meyer-Martin H, Buhl R, Ti ut: $r$, Reuter S. Single and Synergistic Effects of Type 2 Cytokines on Eo it ph.' $^{1}$ 's and Asthma Hallmarks. J Immunol Baltim Md 1950. 2019 Dec 20;

57. Stolarski B, Kurowska-Stolarska M, Kewin P, Xu D, Liew FY. IL-33 Exacerbates Eosinophil-Mediated Airway in : ?mmation. J Immunol. 2010 Sep 15;185(6):3472-80.

58. Fanat AI, Thomson JV, R dfoı K, Nair P, Sehmi R. Human airway smooth muscle promotes eosinophil dif rentation. Clin Exp Allergy J Br Soc Allergy Clin Immunol. 2009 Jul;39(7):1009-1;

59. Yi S, Zhai J, Niu I, Liu G, Wang M, Liu J, et al. Eosinophil recruitment is dynamically reg. lav by interplay among lung dendritic cell subsets after allergen challenge. Nat Con mun. 2018 Sep 24;9(1):1-14.

60. Shen Z-J, Malter JS. Determinants of eosinophil survival and apoptotic cell death. Apoptosis. 2015 Feb 1;20(2):224-34.

61. Muraki M, Gleich GJ, Kita H. Antigen-specific IgG and IgA, but not IgE, activate the effector functions of eosinophils in the presence of antigen. Int Arch Allergy Immunol. 2011;154(2):119-27.

62. Brannan JDP, Lougheed MDM. Airway Hyperresponsiveness in Asthma: Mechanisms, Clinical Significance, and Treatment. Front Physiol [Internet]. 2012 [cited 2020 Sep 17];3. Available from: https://www.frontiersin.org/articles/10.3389/fphys.2012.00460/full

63. Mehta M, Satija S, Paudel KR, Liu G, Chellappan DK, Hansbro PM, et al. Incipient need of targeting airway remodeling using advanced drug delivery in chronic 
respiratory diseases. Future Med Chem [Internet]. [cited 2020 Sep 17]; Available from: https://www.ncbi.nlm.nih.gov/pmc/articles/PMC7319495/

64. Zagai U, Lundahl J, Klominek J, Venge P, Sköld CM. Eosinophil cationic protein stimulates migration of human lung fibroblasts in vitro. Scand J Immunol. 2009 Apr;69(4):381-6.

65. Halwani R, Vazquez-Tello A, Sumi Y, Pureza MA, Bahammam A, Al-Jahdali H, et al. Eosinophils induce airway smooth muscle cell proliferation. J Clin Immunol. 2013 Apr;33(3):595-604.

66. Md S, Wc C, K D, Gm P, Rp P, Mq M, et al. Emerging concepts and directed therapeutics for the management of asthma: regulating the regulators. Inflammopharmacology. 2020 Nov 5;

67. Narendra D, Blixt J, Hanania NA. Immunological bion ark rs in severe asthma. Semin Immunol. 2019 Dec;46:101332.

68. Szefler SJ, Wenzel S, Brown R, Erzurum SC, Far , J v, Hamilton RG, et al. Asthma outcomes: biomarkers. J Allergy Clin Immuno'. ¿`1 ¿ Mar;129(3 Suppl):S9-23.

69. Murayama N, Murayama K. Nasal Discharge Losı: ophils in Childhood Asthma Patients as a Predictive Factor for Persist $\mathrm{nt} f \mathrm{sthma}$. Mediators Inflamm. 2018;2018:2563978.

70. Westerhof GA, Korevaar DA, Anı ${ }^{1} \mathbf{i}$. $\mathrm{k}$ M, Nijs SB de, Groot JC de, Wang J, et al. Biomarkers to identify sputum eosino, hilia in different adult asthma phenotypes. Eur Respir J. 2015 Sep 1;46(3):688-‘

71. Wagener AH, de Nijs SB, J 'ttc “'?, Sousa AR, Weersink EJM, Bel EH, et al. External validation of blood eosinc ${ }_{i}$ hils, $\mathrm{FE}(\mathrm{NO})$ and serum periostin as surrogates for sputum eosinophils in asthma. T. orax. 2015 Feb;70(2):115-20.

72. Hastie AT, Moore WC I . H, Rector BM, Ortega VE, Pascual RM, et al. Biomarker surrogates do not iccu ately predict sputum eosinophil and neutrophil percentages in asthmatic subjec. Allergy Clin Immunol. 2013 Jul;132(1):72-80.

73. Walsh CJ, Zaihra $\mathrm{T}$, Benedetti $\mathrm{A}$, Fugère $\mathrm{C}$, Olivenstein $\mathrm{R}$, Lemière $\mathrm{C}$, et al. Exacerbation risk in severe asthma is stratified by inflammatory phenotype using longitudinal measures of sputum eosinophils. Clin Exp Allergy. 2016;46(10):1291302.

74. Price DB, Rigazio A, Campbell JD, Bleecker ER, Corrigan CJ, Thomas M, et al. Blood eosinophil count and prospective annual asthma disease burden: a UK cohort study. Lancet Respir Med. 2015 Nov;3(11):849-58.

75. Petsky HL, Cates CJ, Kew KM, Chang AB. Tailoring asthma treatment on eosinophilic markers (exhaled nitric oxide or sputum eosinophils): a systematic review and metaanalysis. Thorax. 2018;73(12):1110-9. 
76. Jia G, Erickson RW, Choy DF, Mosesova S, Wu LC, Solberg OD, et al. Periostin is a systemic biomarker of eosinophilic airway inflammation in asthmatic patients. $\mathrm{J}$ Allergy Clin Immunol. 2012 Sep;130(3):647-654.e10.

77. Simpson JL, Yang IA, Upham JW, Reynolds PN, Hodge S, James AL, et al. Periostin levels and eosinophilic inflammation in poorly-controlled asthma. BMC Pulm Med. 2016 Apr 30;16(1):67.

78. Nair P, Ochkur SI, Protheroe C, Radford K, Efthimiadis A, Lee NA, et al. Eosinophil peroxidase in sputum represents a unique biomarker of airway eosinophilia. Allergy. 2013 Sep;68(9):1177-84.

79. Liu T, Wu J, Zhao J, Wang J, Zhang Y, Liu L, et al. Type 2 innate lymphoid cells: A novel biomarker of eosinophilic airway inflammation in oatients with mild to moderate asthma. Respir Med. 2015 Nov;109(11):1391-6.

80. Fricker M, Gibson PG, Powell H, Simpson JL, Yang IA, ' 'Pham JW, et al. A sputum 6-gene signature predicts future exacerbations of pc orly controlled asthma. J Allergy Clin Immunol. 2019 Jul 1;144(1):51-60.e11.

81. Baines KJ, Negewo NA, Gibson PG, Fu J-J, Sin `ns on JL, Wark PA, et al. A Sputum 6 Gene Expression Signature Predicts Inflammaciory ?henotypes and Future Exacerbations of COPD. Int J Chron Obs rv it Pulmon Dis. 2020 Jul 2;15:1577-90.

82. Desai D, Newby C, Symon FA, Hr da $\cdot$ P, Shah S, Gupta S, et al. Elevated Sputum Interleukin-5 and Submucosal Eos." "philia in Obese Individuals with Severe Asthma. Am J Respir Crit Care Med. 2013 Sep i5;188(6):657-63.

83. Sverrild A, Kiilerich P, Brejn or. ^ , Pedersen R, Porsbjerg C, Bergqvist A, et al. Eosinophilic airway inflam $\ldots t_{1} \ldots$ in asthmatic patients is associated with an altered airway microbiome. J Alle. oy Clin Immunol. 2017 Aug 1;140(2):407-417.e11.

84. Dua K, Gupta G, Chella nan DK, Shukla S, Hansbro PM. Targeting bacterial biofilms in pulmonary diseases : n pediatric population. Minerva Pediatr. 2019 Jun;71(3):30910.

85. Chellappan DK, Sz : Ning QL, Su Min SK, Bin SY, Chern PJ, Shi TP, et al. Interactions between microbiome and lungs: Paving new paths for microbiome based bio-engineered drug delivery systems in chronic respiratory diseases. Chem Biol Interact. 2019 Sep 1;310:108732.

86. Hosoki K, Nakamura A, Kainuma K, Sugimoto M, Nagao M, Hiraguchi Y, et al. Differential Activation of Eosinophils by Bacteria Associated with Asthma. Int Arch Allergy Immunol. 2013;161(Suppl. 2):16-22.

87. Patel SS, Casale TB, Cardet JC. Biological therapies for eosinophilic asthma. Expert Opin Biol Ther. 2018 Jul;18(7):747-54.

88. Farne HA, Wilson A, Powell C, Bax L, Milan SJ. Anti- IL5 therapies for asthma. Cochrane Database Syst Rev [Internet]. 2017 Sep 21 [cited 2020 Jan 30];2017(9). Available from: https://www.ncbi.nlm.nih.gov/pmc/articles/PMC6483800/ 
89. Casale TB, Pacou M, Mesana L, Farge G, Sun SX, Castro M. Reslizumab Compared with Benralizumab in Patients with Eosinophilic Asthma: A Systematic Literature Review and Network Meta-Analysis. J Allergy Clin Immunol Pract. 2019;7(1):122130.e1.

90. Lim HF, Nair P. Efficacy and safety of reslizumab in patients with moderate to severe eosinophilic asthma. Expert Rev Respir Med. 2015 Apr;9(2):135-42.

91. Castro M, Zangrilli J, Wechsler ME, Bateman ED, Brusselle GG, Bardin P, et al. Reslizumab for inadequately controlled asthma with elevated blood eosinophil counts: results from two multicentre, parallel, double-blind, randomised, placebo-controlled, phase 3 trials. Lancet Respir Med. 2015 May;3(5):355-66.

92. Haldar P, Brightling CE, Hargadon B, Gupta S, Monteir , W, Sousa A, et al. Mepolizumab and Exacerbations of Refractory Eosinophilı Asthma. N Engl J Med. 2009 Mar 5;360(10):973-84.

93. Nair P, Pizzichini MMM, Kjarsgaard M, Inman ML Et himiadis A, Pizzichini E, et al. Mepolizumab for prednisone-dependent asthma w th sputum eosinophilia. N Engl J Med. 2009 Mar 5;360(10):985-93.

94. Sehmi R, Smith SG, Kjarsgaard M, Radford K, Boulet L-P, Lemiere C, et al. Role of local eosinophilopoietic processes in the $(\mathrm{e}$ e opment of airway eosinophilia in prednisone-dependent severe asthma. $\mathrm{C}$ in Lıp Allergy J Br Soc Allergy Clin Immunol. 2016;46(6):793-802.

95. Busse W, Chupp G, Nagase H, Albers ${ }^{7} \mathrm{C}$, Doyle S, Shen Q, et al. Anti-IL-5 treatments in patients with severe asthma hy $: 100$ oosinophil thresholds: Indirect treatment comparison. J Allergy Clin Ir in u. Jl. 2019;143(1):190-200.e20.

96. Poulakos MN, Cargill SN, Wanneo MF, Wolford AL. Mepolizumab for the treatment of severe eosinophilic as. ' $m$ ma. Am J Health-Syst Pharm AJHP Off J Am Soc HealthSyst Pharm. 2017 Jul 1; ; (13):963-9.

97. Dávila González I Mc reno Benítez F, Quirce S. Benralizumab: A New Approach for the Treatment o1 Severe Eosinophilic Asthma. J Investig Allergol Clin Immunol. 2019 Apr;29(2):84-93

98. Caminati M, Bagnasco D, Vaia R, Senna G. New horizons for the treatment of severe, eosinophilic asthma: benralizumab, a novel precision biologic. Biol Targets Ther. 2019 May 22;13:89-95.

99. Sridhar S, Liu H, Pham T-H, Damera G, Newbold P. Modulation of blood inflammatory markers by benralizumab in patients with eosinophilic airway diseases. Respir Res. 2019 Jan 18;20(1):14.

100. Benralizumab for asthma. Aust Prescr. 2018;41:164-5.

101. Kupryś-Lipińska I, Molińska K, Kuna P. The effect of omalizumab on eosinophilic inflammation of the respiratory tract in patients with allergic asthma. Pneumonol Alergol Pol. 2016;84(4):232-43. 
102. Massanari M, Holgate ST, Busse WW, Jimenez P, Kianifard F, Zeldin R. Effect of omalizumab on peripheral blood eosinophilia in allergic asthma. Respir Med. $2010 \mathrm{Feb}$ $1 ; 104(2): 188-96$.

103. Busse W, Corren J, Lanier BQ, McAlary M, Fowler-Taylor A, Cioppa GD, et al. Omalizumab, anti-IgE recombinant humanized monoclonal antibody, for the treatment of severe allergic asthma. J Allergy Clin Immunol. 2001 Aug;108(2):184-90.

104. Vatrella A, Fabozzi I, Calabrese C, Maselli R, Pelaia G. Dupilumab: a novel treatment for asthma. J Asthma Allergy. 2014 Sep 4;7:123-30.

105. Deeks ED. Dupilumab: A Review in Moderate to Severe Asthma. Drugs. 2019 Nov;79(17):1885-95.

106. Samitas K, Rådinger M, Bossios A. Current update on eosi ophilic lung diseases and anti-IL-5 treatment. Recent Patents Anti-Infect Drug D sc. ?011 Sep 1;6(3):189-205.

107. Kolbeck R, Kozhich A, Koike M, Peng L, Anderssc n C, I, Damschroder MM, et al. MEDI-563, a humanized anti-IL-5 receptor alpha nAv with enhanced antibodydependent cell-mediated cytotoxicity function. : $:{ }^{\prime}$ It $r$ gy Clin Immunol. 2010 Jun;125(6):1344-1353.e2.

108. Bochner BS, Gleich GJ. What targeting e ssi. irphils has taught us about their role in diseases. J Allergy Clin Immunol. 2010 Ju 1, 126(1):16-25.

109. Komai M, Tanaka H, Nagao K, Isı ` 7 ،ki M, Kajiwara D, Miura T, et al. A novel CCchemokine receptor 3 antagonist, Kil; 903 , inhibits airway eosinophilia and subepithelial/peribronchial fibros - induced by repeated antigen challenge in mice. $\mathrm{J}$ Pharmacol Sci. 2010;112(2): [ 0 - 13.

110. Bel EH, ten Brinke A. Ne Ani-Eosinophil Drugs for Asthma and COPD: Targeting the Trait! Chest. 2017 L . 1; 152(6):1276-82.

111. Gonem S, Berair R, Sing puri A, Hartley R, Laurencin MFM, Bacher G, et al.

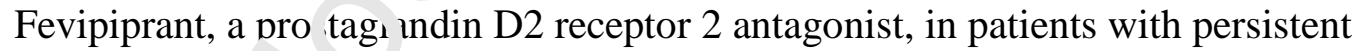
eosinophilic astı. na. a single-centre, randomised, double-blind, parallel-group, placebo-controlled rial. Lancet Respir Med. 2016;4(9):699-707.

112. Watkins N. Novartis' Fevipiprant Fails in Phase 3 Trials for Treatment of Patients with Uncontrolled Asthma [Internet]. Specialty Pharma Journal. 2019 [cited 2020 Dec 17]. Available from: https://www.spjnews.com/2019/12/16/novartis-fevipiprant-fails-inphase-3-trials-for-treatment-of-patients-with-uncontrolled-asthma/

113. Gauvreau GM, O’Byrne PM, Boulet L-P, Wang Y, Cockcroft D, Bigler J, et al. Effects of an Anti-TSLP Antibody on Allergen-Induced Asthmatic Responses [Internet]. http://dx.doi.org/10.1056/NEJMoa1402895. 2014 [cited 2020 Jan 31]. Available from: https://www.nejm.org/doi/10.1056/NEJMoa1402895

114. Mehta M, Deeksha null, Tewari D, Gupta G, Awasthi R, Singh H, et al. Oligonucleotide therapy: An emerging focus area for drug delivery in chronic inflammatory respiratory diseases. Chem Biol Interact. 2019 Aug 1;308:206-15. 
115. Dua K, Wadhwa R, Singhvi G, Rapalli V, Shukla SD, Shastri MD, et al. The potential of siRNA based drug delivery in respiratory disorders: Recent advances and progress. Drug Dev Res. 2019;80(6):714-30.

116. Dua K, Chellappan DK, Singhvi G, de Jesus Andreoli Pinto T, Gupta G, Hansbro PM. Targeting microRNAs using nanotechnology in pulmonary diseases. Panminerva Med. 2018 Dec;60(4):230-1.

117. Mehta M, Chellappan DK, Wich PR, Hansbro NG, Hansbro PM, Dua K. miRNA nanotherapeutics: potential and challenges in respiratory disorders. Future Med Chem. 2020 Apr 9;12(11):987-90.

118. Imaoka H, Campbell H, Babirad I, Watson RM, Mistry M, Sehmi R, et al. TPI ASM8 reduces eosinophil progenitors in sputum after allergen challenge. Clin Exp Allergy $\mathbf{J}$ Br Soc Allergy Clin Immunol. 2011 Dec;41(12):1740-6.

119. Ramsahai JM, Wark PA. Appropriate use of oral cortirc ioids for severe asthma. Med J Aust. 2018 16;209(S2):S18-21.

120. Durham AL, Caramori G, Chung KF, Adcock Fivi. 1 argeted anti-inflammatory therapeutics in asthma and chronic obstructive . 'ns, disease. Transl Res J Lab Clin Med. 2016 Jan;167(1):192-203.

121. Dente FL, Bacci E, Bartoli ML, Cianch tt1 ₹, Costa F, Di Franco A, et al. Effects of oral prednisone on sputum eosinor anc anc cytokines in patients with severe refractory asthma. Ann Allergy Asthma Immı " sl Off Publ Am Coll Allergy Asthma Immunol. 2010 Jun;104(6):464-70.

122. Prazma CM, Bel EH, Price R j, L madford ES, Albers FC, Yancey SW. Oral

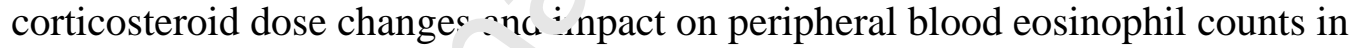
patients with severe eosinc , hilic asthma: a post hoc analysis. Respir Res. 2019 May $3 ; 20(1): 83$.

123. Lommatzsch M, Klein M, Stoll P, Virchow JC. Impact of an increase in the inhaled corticosteroid dos : on blood eosinophils in asthma. Thorax. 2019;74(4):417-8.

124. Cherk Yong DO. S ker SR, Wadhwa R, Chellappan DK, Madheswaran T, Panneerselvam J, et al. Preparation, characterization and in-vitro efficacy of quercetin loaded liquid crystalline nanoparticles for the treatment of asthma. J Drug Deliv Sci Technol. 2019 Dec 1;54:101297.

125. Sakai-Kashiwabara M, Asano K. Inhibitory Action of Quercetin on Eosinophil Activation In Vitro. Evid-Based Complement Altern Med ECAM [Internet]. 2013 [cited 2020 Apr 18];2013. Available from: https://www.ncbi.nlm.nih.gov/pmc/articles/PMC3690238/

126. Sakai-Kashiwabara M, Abe S, Asano K. Suppressive activity of quercetin on the production of eosinophil chemoattractants from eosinophils in vitro. Vivo Athens Greece. 2014 Aug;28(4):515-22. 
127. Hewlings SJ, Kalman DS. Curcumin: A Review of Its' Effects on Human Health. Foods [Internet]. 2017 Oct 22 [cited 2020 Apr 18];6(10). Available from: https://www.ncbi.nlm.nih.gov/pmc/articles/PMC5664031/

128. Ng ZY, Wong J-Y, Panneerselvam J, Madheswaran T, Kumar P, Pillay V, et al. Assessing the potential of liposomes loaded with curcumin as a therapeutic intervention in asthma. Colloids Surf B Biointerfaces. 2018 Dec 1;172:51-9.

129. Chellappan DK, Ng ZY, Wong J-Y, Hsu A, Wark P, Hansbro N, et al. Immunological axis of curcumin-loaded vesicular drug delivery systems. Future Med Chem. 2018 Apr $1 ; 10(8): 839-44$.

130. Chellappan DK, Hansbro PM, Dua K, Hsu A, Gupta G, Ng ZY, et al. Vesicular Systems Containing Curcumin and Their Applications ir Respiratory Disorders - A Mini Review. Pharm Nanotechnol. 2017;5(4):250-4.

131. Vestbo J, Hurd SS, Agustí AG, Jones PW, Vogelmeier ¿ ' inzueto A, et al. Global Strategy for the Diagnosis, Management, and Preve ition of Chronic Obstructive Pulmonary Disease. Am J Respir Crit Care Med. '913 Feb 15;187(4):347-65.

132. Wadhwa R, Aggarwal T, Malyla V, Kumar N, Fıraa G, Chellappan DK, et al. Identification of biomarkers and genetic apnrc ache toward chronic obstructive pulmonary disease. J Cell Physiol. 2019;:34 (10):16703-23.

133. Mehta M, Deeksha, Tewari D, Gur a I, F sasthi R, Singh H, et al. Oligonucleotide therapy: An emerging focus area tc - arug delivery in chronic inflammatory respiratory diseases. Chem Biol Interact. $2019 \mathrm{Au}_{\S}$ 1;308:206-15.

134. Chellappan DK, Yee LW, Xu in i ' , Kunalan K, Rou LC, Jean LS, et al. Targeting neutrophils using novel dr'。 $t \epsilon$ ': ery systems in chronic respiratory diseases. Drug Dev Res. 2020;81(4):419-.?5.

135. van Haarst A, McGarve, I, Paglialunga S. Review of Drug Development Guidance to Treat Chronic Obstric: $\mathrm{v}$; Pulmonary Disease: US and EU Perspectives. Clin Pharmacol Ther. 2019 Dec;106(6):1222-35.

136. Hogg JC. A brief $\mathrm{r} f$ view of chronic obstructive pulmonary disease. Can Respir J J Can Thorac Soc. 2012;19(6):381-4.

137. Barnes PJ, Burney PGJ, Silverman EK, Celli BR, Vestbo J, Wedzicha JA, et al. Chronic obstructive pulmonary disease. Nat Rev Dis Primer. 2015 03;1:15076.

138. Mehta M, Deeksha null, Sharma N, Vyas M, Khurana N, Maurya PK, et al. Interactions with the macrophages: An emerging targeted approach using novel drug delivery systems in respiratory diseases. Chem Biol Interact. 2019 May 1;304:10-9.

139. Butler A, Walton GM, Sapey E. Neutrophilic Inflammation in the Pathogenesis of Chronic Obstructive Pulmonary Disease. COPD J Chronic Obstr Pulm Dis. 2018 Jul 4;15(4):392-404.

140. Tashkin DP, Wechsler ME. Role of eosinophils in airway inflammation of chronic obstructive pulmonary disease. Int J Chron Obstruct Pulmon Dis. 2018;13:335-49. 
141. Kim VL, Coombs NA, Staples KJ, Ostridge KK, Williams NP, Wootton SA, et al. Impact and associations of eosinophilic inflammation in COPD: analysis of the AERIS cohort. Eur Respir J. 2017;50(4).

142. Tworek D, Antczak A. Eosinophilic COPD - a distinct phenotype of the disease. Adv Respir Med. 2017;85(5):271-6.

143. George L, Brightling CE. Eosinophilic airway inflammation: role in asthma and chronic obstructive pulmonary disease. Ther Adv Chronic Dis. 2016 Jan;7(1):34-51.

144. Eltboli O, Bafadhel M, Hollins F, Wright A, Hargadon B, Kulkarni N, et al. COPD exacerbation severity and frequency is associated with impaired macrophage efferocytosis of eosinophils. BMC Pulm Med. 2014 Jul 9;14:112.

145. Kume H, Hojo M, Hashimoto N. Eosinophil Inflammation 'nd Hyperresponsiveness in the Airways as Phenotypes of COPD, and Usefulness c $i$ Itr.aled Glucocorticosteroids. Front Pharmacol. 2019;10:765.

146. Singh D, Kolsum U, Brightling CE, Locantore N, Agusi A, Tal-Singer R. Eosinophilic inflammation in COPD: prevalence and clinica' . ' 'ı ucteristics. Eur Respir J. 2014 Dec 1;44(6):1697-700.

147. Cukic V, Lovre V, Dragisic D, Ustamujic A. Asthma and Chronic Obstructive Pulmonary Disease (COPD) - Differen es n..d Similarities. Mater Socio-Medica. 2012;24(2):100-5.

148. Pignatti P, Visca D, Cherubino F, Zan ${ }_{1}$ ogna E, Lucini E, Saderi L, et al. Do blood eosinophils strictly reflect airway inflammation in COPD? Comparison with asthmatic patients. Respir Res. 2019 Ju' 11,? ?)(1):145.

149. Couillard S, Larivée P, Cc rteau J, Vanasse A. Eosinophils in COPD Exacerbations Are Associated With Inc eased Readmissions. Chest. 2017 Feb;151(2):366-73.

150. Hyun D-G, Lee JH, L: Y-M, Lee SW, Lee SD, Lee JS. Association of plasma fibrinogen concen ratı ns and blood eosinophil counts with clinical phenotypes of COPD. Int J Tus rc zung Dis Off J Int Union Tuberc Lung Dis. 2019 01;23(9):103541.

151. Thong L, O'Driscoll M, Casey C, Kennedy M, Plant BJ, Henry MT, et al. Eosinophils and COPD Readmission. Chest. 2017;151(3):724-5.

152. Fuschillo S, Molino A, Stellato C, Motta A, Maniscalco M. Blood eosinophils as biomarkers of therapeutic response to chronic obstructive pulmonary disease: Still work in progress. Eur J Intern Med. 2019 Oct;68:1-5.

153. Wadhwa R, Aggarwal T, Malyla V, Kumar N, Gupta G, Chellappan DK, et al. Identification of biomarkers and genetic approaches toward chronic obstructive pulmonary disease. J Cell Physiol. 2019 Aug;234(10):16703-23.

154. Tinè M, Biondini D, Semenzato U, Bazzan E, Cosio MG, Saetta M, et al. Reassessing the Role of Eosinophils as a Biomarker in Chronic Obstructive Pulmonary Disease. J Clin Med. 2019 Jul 2;8(7). 
155. Vedel-Krogh S, Nielsen SF, Lange P, Vestbo J, Nordestgaard BG. Blood Eosinophils and Exacerbations in Chronic Obstructive Pulmonary Disease. The Copenhagen General Population Study. Am J Respir Crit Care Med. 2016 01;193(9):965-74.

156. Hastie AT, Martinez FJ, Curtis JL, Doerschuk CM, Hansel NN, Christenson S, et al. Association of sputum and blood eosinophil concentrations with clinical measures of COPD severity: an analysis of the SPIROMICS cohort. Lancet Respir Med. 2017;5(12):956-67.

157. Oh Y-M, Lee KS, Hong Y, Hwang SC, Kim JY, Kim DK, et al. Blood eosinophil count as a prognostic biomarker in COPD. Int J Chron Obstruct Pulmon Dis. 2018 Oct 31;13:3589-96.

158. DiSantostefano RL, Hinds D, Le HV, Barnes NC. Relati onship between blood eosinophils and clinical characteristics in a cross-sectional tudy of a US populationbased COPD cohort. Respir Med. 2016 Mar;112:88-96.

159. Ko FWS, Chan KP, Ngai J, Ng S-S, Yip WH, Ip A, at as Blood eosinophil count as a predictor of hospital length of stay in COPD exac. rbatıons. Respirol Carlton Vic. 2019 Aug 6;

160. Mendy A, Forno E, Niyonsenga T, Gasana J. 'slooc biomarkers as predictors of longterm mortality in COPD. Clin Respir J. 2(11's i 1ay;12(5):1891-9.

161. Gonzalez-Barcala F-J, San-Jose M E, Vit. J-Fontarigo J-J, Calvo-Alvarez U, Carreira J-M, Garcia-Sanz M-T, et al. Bloo ' $₹$ osinophils could be useful as a biomarker in chronic obstructive pulmonary disease exacerbations. Int J Clin Pract. 2019 Oct $1 ; \mathrm{e} 13423$.

162. Couillard S, Larivée P, Cor . +ea: , , Vanasse A. Eosinophils in COPD Exacerbations Are Associated With Incrc. 'sed Readmissions. Chest. 2017 Feb;151(2):366-73.

163. Bélanger M, Couillard S, Cuurteau J, Larivée P, Poder TG, Carrier N, et al. Eosinophil counts in first COPD $1 \mathrm{n}$, italizations: a comparison of health service utilization. Int $\mathbf{J}$ Chron Obstruct Pı lmo 1 Dis. 2018;13:3045-54.

164. Cheng S-L, Lin C--) I. Effectiveness using higher inhaled corticosteroid dosage in patients with COPD by different blood eosinophilic counts. Int J Chron Obstruct Pulmon Dis. 2016;11:2341-8.

165. Hillas G, Papaporfyriou A, Dimakou K, Papaioannou AI. Pharmacological treatment of stable COPD: need for a simplified approach. Postgrad Med. 2019 Dec 18;

166. Bafadhel M, Peterson S, Blas MAD, Calverley PM, Rennard SI, Richter K, et al. Predictors of exacerbation risk and response to budesonide in patients with chronic obstructive pulmonary disease: a post-hoc analysis of three randomised trials. Lancet Respir Med. 2018 Feb 1;6(2):117-26.

167. Pascoe S, Locantore N, Dransfield MT, Barnes NC, Pavord ID. Blood eosinophil counts, exacerbations, and response to the addition of inhaled fluticasone furoate to vilanterol in patients with chronic obstructive pulmonary disease: a secondary analysis 
of data from two parallel randomised controlled trials. Lancet Respir Med. 2015 Jun;3(6):435-42.

168. Siddiqui SH, Guasconi A, Vestbo J, Jones P, Agusti A, Paggiaro P, et al. Blood Eosinophils: A Biomarker of Response to Extrafine Beclomethasone/Formoterol in Chronic Obstructive Pulmonary Disease. Am J Respir Crit Care Med. 2015 Aug 15;192(4):523-5.

169. Pavord ID, Lettis S, Locantore N, Pascoe S, Jones PW, Wedzicha JA, et al. Blood eosinophils and inhaled corticosteroid/long-acting $\beta$-2 agonist efficacy in COPD. Thorax. 2016 Feb;71(2):118-25.

170. Vestbo J, Papi A, Corradi M, Blazhko V, Montagna I, Francisco C, et al. Single inhaler extrafine triple therapy versus long-acting muscarinic an agonist therapy for chronic obstructive pulmonary disease (TRINITY): a double-blina, , rarallel group, randomised controlled trial. The Lancet. 2017 May 13;389(10082): 191 -29.

171. McDonald CF. Eosinophils in chronic obstructive p lme nary disease: are they just another biomarker? Curr Opin Pulm Med. 2020 Jin 3;

172. Oshagbemi OA, Franssen FME, van Kraaij S, ' 'rae zen DCW, Wouters EFM, Maitland-van der Zee AH, et al. Blood Eosinc phil Counts, Withdrawal of Inhaled Corticosteroids and Risk of COPD Exace b iti nns and Mortality in the Clinical Practice Research Datalink (CPRD). COPD. 2019;1ú 2):152-9.

173. Watz H, Tetzlaff K, Wouters EFM, V.,rsten A, Magnussen H, Rodriguez-Roisin R, et al. Blood eosinophil count and exaceruations in severe chronic obstructive pulmonary disease after withdrawal of inhale.' corticosteroids: a post-hoc analysis of the WISDOM trial. Lancet Respi · I … 2016 May 1;4(5):390-8.

174. Chapman KR, Hurst JR, F `nt S-M, Larbig M, Fogel R, Guerin T, et al. Long-Term Triple Therapy De-escal tion to Indacaterol/Glycopyrronium in Patients with Chronic Obstructive Pulmonary L'isease (SUNSET): A Randomized, Double-Blind, TripleDummy Clinical Trial. ^..n J Respir Crit Care Med. 2018 May 20;198(3):329-39.

175. Magnussen H, Li se §, Rodriguez-Roisin R, Kirsten A, Watz H, Tetzlaff K, et al. Withdrawal of Irh : ied Glucocorticoids and Exacerbations of COPD [Internet]. http://dx.doi.org/10.1056/NEJMoa1407154. Massachusetts Medical Society; 2014 [cited 2020 Mar 6]. Available from: https://www.nejm.org/doi/10.1056/NEJMoa1407154

176. Calzetta L, Matera MG, Braido F, Contoli M, Corsico A, Di Marco F, et al. Withdrawal of inhaled corticosteroids in COPD: A meta-analysis. Pulm Pharmacol Ther. 2017 Aug 1;45:148-58.

177. Vestbo J, Anderson JA, Brook RD, Calverley PMA, Celli B, Crim CC, et al. Effect of Treatment Withdrawal on Outcomes in the SUMMIT Study. In: C41 LONG ACTING BRONCHODILATOR THERAPY IN COPD II [Internet]. American Thoracic Society; 2017 [cited 2020 Mar 6]. p. A5483-A5483. (American Thoracic Society International Conference Abstracts). Available from: 
https://www.atsjournals.org/doi/abs/10.1164/ajrccm-

conference.2017.195.1_MeetingAbstracts.A5483

178. Vestbo J, Fabbri L, Papi A, Petruzzelli S, Scuri M, Guasconi A, et al. Inhaled corticosteroid containing combinations and mortality in COPD. Eur Respir J [Internet]. 2018 Dec 1 [cited 2020 Apr 11];52(6). Available from: https://erj.ersjournals.com/content/52/6/1801230

179. Vestbo J, Anderson JA, Brook RD, Calverley PMA, Celli BR, Crim C, et al. Fluticasone furoate and vilanterol and survival in chronic obstructive pulmonary disease with heightened cardiovascular risk (SUMMIT): a double-blind randomised controlled trial. Lancet Lond Engl. 2016 Apr 30;387(10030):1817-26.

180. Kreindler JL, Watkins ML, Lettis S, Tal-Singer R, Loca tore N. Effect of inhaled corticosteroids on blood eosinophil count in steroid-naïve $p$ 'tients with COPD. BMJ Open Respir Res. 2016;3(1):e000151.

181. Schumann DM, Tamm M, Kostikas K, Stolz D. Sta ility of the Blood Eosinophilic Phenotype in Stable and Exacerbated COPD. Che †. 2u19 Sep;156(3):456-65.

182. Negewo NA, McDonald VM, Baines KJ, Warn DA, Simpson JL, Jones PW, et al. Peripheral blood eosinophils: a surrogate mar!.er to: airway eosinophilia in stable COPD. Int J Chron Obstruct Pulmon Dis. 2r,1 \%;11:1495-504.

183. Oshagbemi OA, Burden AM, Brae'.el DL'N, Henskens Y, Wouters EFM, Driessen JHM, et al. Stability of Blood Eosı - shils in Patients with Chronic Obstructive Pulmonary Disease and in Cortrol Subjects, and the Impact of Sex, Age, Smoking, and Baseline Counts. Am J Respir Cr. Care Med. 2017 15;195(10):1402-4.

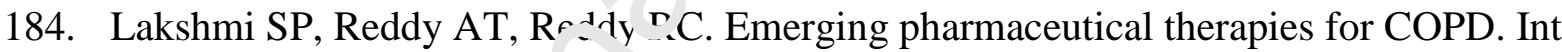
J Chron Obstruct Pulmon ' 'is. ' 017 Jul 21;12:2141-56.

185. Brightling CE, Bleeckeı $\mathrm{C}_{\mathrm{K}}$, Panettieri RA, Bafadhel M, She D, Ward CK, et al. Benralizumab for chro. ir obstructive pulmonary disease and sputum eosinophilia: a randomised, dnub e-bi nd, placebo-controlled, phase 2a study. Lancet Respir Med. 2014 Nov;2(11): ¿ ${ }^{9} 1-901$.

186. Pavord ID, Chanez P, Criner GJ, Kerstjens HAM, Korn S, Lugogo N, et al. Mepolizumab for Eosinophilic Chronic Obstructive Pulmonary Disease. N Engl J Med. 2017 26;377(17):1613-29.

187. Assaf S, Hanania NA. Novel therapeutic targets and drug development for the precision treatment of COPD. Expert Rev Precis Med Drug Dev. 2019 May $4 ; 4(3): 121-8$.

188. Gross NJ, Barnes PJ. New Therapies for Asthma and Chronic Obstructive Pulmonary Disease. Am J Respir Crit Care Med. 2016 Dec 6;195(2):159-66.

189. Criner GJ, Celli BR, Brightling CE, Agusti A, Papi A, Singh D, et al. Benralizumab for the Prevention of COPD Exacerbations. N Engl J Med. 2019 12;381(11):1023-34. 
190. Sridhar S, Liu H, Pham T-H, Damera G, Newbold P. Modulation of blood inflammatory markers by benralizumab in patients with eosinophilic airway diseases. Respir Res. 2019 Jan 18;20(1):14.

191. Greulich T, Hohlfeld JM, Neuser P, Lueer K, Klemmer A, Schade-Brittinger C, et al. A GATA3-specific DNAzyme attenuates sputum eosinophilia in eosinophilic COPD patients: a feasibility randomized clinical trial. Respir Res. 2018 04;19(1):55.

192. Turowska A, Librizzi D, Baumgartl N, Kuhlmann J, Dicke T, Merkel O, et al. Biodistribution of the GATA-3-specific DNAzyme hgd40 after inhalative exposure in mice, rats and dogs. Toxicol Appl Pharmacol. 2013 Oct 15;272(2):365-72.

193. Brown SD, White R, Tobin P. Keep them breathing: Cystic fibrosis pathophysiology, diagnosis, and treatment. J Am Acad PAs. 2017 May;30 5):23-27.

194. Bergeron C, Cantin AM. Cystic Fibrosis: Pathophysiol gy of Lung Disease. Semin Respir Crit Care Med. 2019 Dec;40(6):715-26.

195. Zhang L, Borish L, Smith A, Somerville L, Albor D. use of mepolizumab in adult patients with cystic fibrosis and an eosinophilir pi. on thpe: case series. Allergy Asthma Clin Immunol Off J Can Soc Allergy L'in .mmunol. 2020;16:3.

196. Haack A, Aragão GG, Novaes MRCG. P: th Jrhysiology of cystic fibrosis and drugs used in associated digestive tract diseas :s. $\because$ orld J Gastroenterol WJG. 2013 Dec 14;19(46):8552-61.

197. Dua K, De Jesus Andreoli Pintn T, Chı llappan DK, Gupta G, Bebawy M, Hansbro PM. Advancements in nano drug deliv ry systems: A challenge for biofilms in respiratory diseases. 2018 Mar 1 [cited 2' 2', '^ pr 18]; Available from:

https://opus.lib.uts.edu.au/t_nd_-10453/128257

198. Davies JC, Alton EWFV Bush A. Cystic fibrosis. BMJ. 2007 Dec 13;335(7632):1255-9.

199. Rey MM, Bonk N P, r adjiliadis D. Cystic Fibrosis: Emerging Understanding and Therapies. Annu Rt. Med. 2019 27;70:197-210.

200. Cohen-Cymberknoh M, Kerem E, Ferkol T, Elizur A. Airway inflammation in cystic fibrosis: molecular mechanisms and clinical implications. Thorax. $2013 \mathrm{Dec}$ 1;68(12):1157-62.

201. Roesch EA, Nichols DP, Chmiel JF. Inflammation in cystic fibrosis: An update. Pediatr Pulmonol. 2018;53(S3):S30-50.

202. Tiringer K, Treis A, Fucik P, Gona M, Gruber S, Renner S, et al. A Th17- and Th2skewed Cytokine Profile in Cystic Fibrosis Lungs Represents a Potential Risk Factor for Pseudomonas aeruginosa Infection. Am J Respir Crit Care Med. 2013 Mar 15;187(6):621-9.

203. Koller DY, Götz M, Eichler I, Urbanek R. Eosinophilic activation in cystic fibrosis. Thorax. 1994 May;49(5):496-9. 
204. Dy K, R U, M G. Increased degranulation of eosinophil and neutrophil granulocytes in cystic fibrosis. Am J Respir Crit Care Med. 1995 Aug 1;152(2):629-33.

205. Koller DY, Nilsson M, Enander I, Venge P, Eichler I. Serum eosinophil cationic protein, eosinophil protein $\mathrm{X}$ and eosinophil peroxidase in relation to pulmonary function in cystic fibrosis. Clin Exp Allergy J Br Soc Allergy Clin Immunol. 1998 Feb;28(2):241-8.

206. Dy K, I N, J O, R U, I E. Cytokine concentrations in sputum from patients with cystic fibrosis and their relation to eosinophil activity. Am J Respir Crit Care Med. 1997 Mar $1 ; 155(3): 1050-4$.

207. Condren ME, Bradshaw MD. Ivacaftor: A Novel Gene-Based Therapeutic Approach for Cystic Fibrosis. J Pediatr Pharmacol Ther JPPT. 201 ;;18(1):8-13.

208. Dua K, Awasthi R, Madan JR, Chellappan DK, Nalluri BN Gupta G, et al. Novel drug delivery approaches in treating pulmonary fibrosis. Pan ${ }_{1}{ }^{-}$. erva Med. 2018 Dec;60(4):238-40.

209. Porsio B, Craparo EF, Mauro N, Giammona G C vailaro G. Mucus and CellPenetrating Nanoparticles Embedded in Nano-1 to Micro Formulations for Pulmonary Delivery of Ivacaftor in Patients with Cystic Fıbrosis. ACS Appl Mater Interfaces. 2018 Jan 10;10(1):165-81.

210. Jain V, Bhardwaj A. Pneumonia P $\cdot \mathrm{n}_{\mathrm{L}} \log _{\mathrm{j}}$. In: StatPearls [Internet]. Treasure Island (FL): StatPearls Publishing; 2020 L ed 2020 Apr 6]. Available from: http://www.ncbi.nlm.nih.gov// ooks/NıK526116/

211. Mackenzie G. The definition $\operatorname{tn}^{-1}$ assification of pneumonia. Pneumonia [Internet]. 2016 Aug 22 [cited $2020 A_{F}$; $6 ;$ s. Available from: https://www.ncbi.nlm.nih.e ov/pmc/articles/PMC5471962/

212. Pahal P, Sharma S. Eosı pphilic Pneumonia. In: StatPearls [Internet]. Treasure Island (FL): StatPearls Puhl1s'ir. g; 2020 [cited 2020 Apr 7]. Available from: http://www.nchi.n m.r h.gov/books/NBK537169/

213. De Giacomi F, Vas allo R, Yi ES, Ryu JH. Acute Eosinophilic Pneumonia. Causes, Diagnosis, and Management. Am J Respir Crit Care Med. 2017 Dec 5;197(6):728-36.

214. Akuthota P, Weller PF. Eosinophilic Pneumonias. Clin Microbiol Rev. 2012 Oct 1;25(4):649-60.

215. Katoh S, Ikeda M, Matsumoto N, Shimizu H, Abe M, Ohue Y, et al. Possible Role of IL-25 in Eosinophilic Lung Inflammation in Patients with Chronic Eosinophilic Pneumonia. Lung. 2017 Dec 1;195(6):707-12.

216. Endo Y, Nakayama T. Pathogenic Th2 (Tpath2) cells in airway inflammation. Oncotarget. 2015 Oct 8;6(32):32303-4.

217. Cottin V. Eosinophilic Lung Diseases. Clin Chest Med. 2016 Sep 1;37(3):535-56. 
218. Suzuki Y, Suda T. Eosinophilic pneumonia: A review of the previous literature, causes, diagnosis, and management. Allergol Int. 2019 Oct 1;68(4):413-9.

219. Crowe M, Robinson D, Sagar M, Chen L, Ghamande S. Chronic eosinophilic pneumonia: clinical perspectives. Ther Clin Risk Manag. 2019 Mar 13;15:397-403.

220. Abughanimeh O, Tahboub M, Abu Ghanimeh M. Metastatic Lung Adenocarcinoma Presenting with Hypereosinophilia. Cureus. 2018 Jun 22;10(6):e2866.

221. Sharma P, Mehta M, Dhanjal DS, Kaur S, Gupta G, Singh H, et al. Emerging trends in the novel drug delivery approaches for the treatment of lung cancer. Chem Biol Interact. 2019 Aug 25;309:108720.

222. Gupta G, de Jesus Andreoli Pinto T, Chellappan DK, Mishra A, Malipeddi H, Dua K. A clinical update on metformin and lung cancer in diabet $\_$natients. Panminerva Med. 2018 Jun;60(2):70-5.

223. Varricchi G, Galdiero MR, Loffredo S, Lucarini V, Mar ıne G, Mattei F, et al. Eosinophils: The unsung heroes in cancer? Onco: nmuılogy. 2017 Nov 13;7(2).

224. Davis BP, Rothenberg ME. Eosinophils and ca.' cer Cancer Immunol Res. 2014 Jan;2(1):1-8.

225. Carretero R, Sektioglu IM, Garbi N, Sal gaı JC, Beckhove P, Hämmerling GJ. Eosinophils orchestrate cancer reje $4, \mathrm{n} \mathrm{L}_{2}$, normalizing tumor vessels and enhancing infiltration of CD8(+) T cells. Nat 'm nunol. 2015 Jun;16(6):609-17.

226. Walsh M-T, Connell K, Sheahan AM, Gleich GJ, Costello RW. Eosinophil peroxidase signals via epidermal growth $\mathrm{ar}, \mathrm{r}-2$ to induce cell proliferation. Am J Respir Cell Mol Biol. 2011 Nov;45(5): $\$ 16-5$.

227. Lou Y, Marin-Acevedo 'A, vishnu P, Manochakian R, Dholaria B, Soyano A, et al.

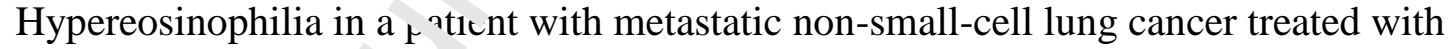
antiprogrammed cell c a at 11 (anti-PD-1) therapy. Immunotherapy. 2019;11(7):577-84.

228. Sharma P, Mehı Ni, Jhanjal DS, Kaur S, Gupta G, Singh H, et al. Emerging trends in the novel drug deli ery approaches for the treatment of lung cancer. Chem Biol Interact. 2019 Aug 25;309:108720.

229. Dua K, Madan JR, Chellappan DK, Gupta G. Nanotechnology in drug delivery gaining new perspectives in respiratory diseases. Panminerva Med. 2018;60(3):135-6.

230. Takada K, Shimokawa M, Tanaka K, Kohashi K, Haro A, Osoegawa A, et al. Association between peripheral blood markers and immune-related factors on tumor cells in patients with resected primary lung adenocarcinoma. PloS One. 2019;14(6):e0217991.

231. Liu M, Wang X, Wang L, Ma X, Gong Z, Zhang S, et al. Targeting the IDO1 pathway in cancer: from bench to bedside. J Hematol OncolJ Hematol Oncol [Internet]. 2018 Aug 2 [cited 2020 Apr 7];11. Available from: https://www.ncbi.nlm.nih.gov/pmc/articles/PMC6090955/ 
232. Tanizaki J, Haratani K, Hayashi H, Chiba Y, Nakamura Y, Yonesaka K, et al. Peripheral Blood Biomarkers Associated with Clinical Outcome in Non-Small Cell Lung Cancer Patients Treated with Nivolumab. J Thorac Oncol Off Publ Int Assoc Study Lung Cancer. 2018;13(1):97-105.

233. Taghizadeh N, Vonk JM, Hospers JJ, Postma DS, de Vries EGE, Schouten JP, et al. Objective allergy markers and risk of cancer mortality and hospitalization in a large population-based cohort. Cancer Causes Control CCC. 2015 Jan;26(1):99-109.

234. Stankovic B, Bjørhovde HAK, Skarshaug R, Aamodt H, Frafjord A, Müller E, et al. Immune Cell Composition in Human Non-small Cell Lung Cancer. Front Immunol. 2018;9:3101.

235. Ye L, Wang H, Li H, Liu H, Lv T, Song Y, et al. Eosino shil peroxidase overexpression predicts the clinical outcome of patients with $\rho_{\mathbf{1}}$ : mary lung adenocarcinoma. J Cancer. 2019;10(4):1032-8.

236. Johnson ER, Matthay MA. Acute Lung Injury: Epic əmi logy, Pathogenesis, and Treatment. J Aerosol Med Pulm Drug Deliv. 201乞 Aug;23(4):243-52.

237. Willetts L, Parker K, Wesselius LJ, Protheroe '`` , aben E, Graziano P, et al. Immunodetection of occult eosinophils in lun tissue biopsies may help predict survival in acute lung injury. Respir Res. $2011 ; 12(1): 116$.

238. Zilaee M, Hosseini SA, Jafarirad S, A oh zzhadian F, Cheraghian B, Namjoyan F, et al. An evaluation of the effects of $s, f$.ron supplementation on the asthma clinical symptoms and asthma severity in patie. its with mild and moderate persistent allergic asthma: a double-blind, randomiz $t$ placebo-controlled trial. Respir Res.

2019;20(1):39-39.

239. Kurosawa M, Sutoh E. Pr necive Open-Label Study of 48-Week Subcutaneous Administration of Mepo. ' rumab in Japanese Patients With Severe Eosinophilic Asthma. J Investig Aller ह 1 Clin Immunol. 2019;29(1):40-5.

240. Ramos-Martínez I , Lc pez-Vancell MR, Fernández de Córdova-Aguirre JC, RojasSerrano J, Chava. "ía A, Velasco-Medina A, et al. Reduction of respiratory infections in asthma patients sur plemented with vitamin D is related to increased serum IL-10 and IFN $\gamma$ levels and cathelicidin expression. Cytokine. 2018;108:239-46.

241. Bleecker ER, Wechsler ME, FitzGerald JM, Menzies-Gow A, Wu Y, Hirsch I, et al. Baseline patient factors impact on the clinical efficacy of benralizumab for severe asthma. Eur Respir J. 2018;52(4).

242. Chipps BE, Newbold P, Hirsch I, Trudo F, Goldman M. Benralizumab efficacy by atopy status and serum immunoglobulin $\mathrm{E}$ for patients with severe, uncontrolled asthma. Ann Allergy Asthma Immunol Off Publ Am Coll Allergy Asthma Immunol. 2018;120(5):504-511.e4.

243. Lugogo N, Domingo C, Chanez P, Leigh R, Gilson MJ, Price RG, et al. Long-term Efficacy and Safety of Mepolizumab in Patients With Severe Eosinophilic Asthma: A Multi-center, Open-label, Phase IIIb Study. Clin Ther. 2016;38(9):2058-2070.e1. 
244. Rossios C, Pavlidis S, Hoda U, Kuo C-H, Wiegman C, Russell K, et al. Sputum transcriptomics reveal upregulation of IL-1 receptor family members in patients with severe asthma. J Allergy Clin Immunol. 2018;141(2):560-70.

245. Casale TB, Chipps BE, Rosén K, Trzaskoma B, Haselkorn T, Omachi TA, et al. Response to omalizumab using patient enrichment criteria from trials of novel biologics in asthma. Allergy. 2018;73(2):490-7.

246. Ortega H, Yancey SW, Keene ON, Gunsoy NB, Albers FC, Howarth PH. Asthma Exacerbations Associated with Lung Function Decline in Patients with Severe Eosinophilic Asthma. J Allergy Clin Immunol Pract. 2018;6(3):980-986.e1.

247. Casale TB, Bateman ED, Vandewalker M, Virchow JC, Schmidt H, Engel M, et al. Tiotropium Respimat Add-on Is Efficacious in Symptom atic Asthma, Independent of T2 Phenotype. J Allergy Clin Immunol Pract. 2018;6(3):9_? -935.e9.

248. Chupp GL, Bradford ES, Albers FC, Bratton DJ, Wano-_ ${ }^{\prime}$ aj J, Nelsen LM, et al. Efficacy of mepolizumab add-on therapy on health- elat :d quality of life and markers of asthma control in severe eosinophilic asthma ('USCA): a randomised, doubleblind, placebo-controlled, parallel-group, multi $\mathrm{e}_{\mathbf{\prime}}{ }^{\mathrm{r}} \mathrm{r}$, phase $3 \mathrm{~b}$ trial. Lancet Respir Med. 2017;5(5):390-400.

249. Denlinger LC, Phillips BR, Ramratnam S P.o s K, Bhakta NR, Cardet JC, et al. Inflammatory and Comorbid Features c Paients with Severe Asthma and Frequent Exacerbations. Am J Respir Crit C.re Meci. 2017;195(3):302-13.

250. Ledford D, Busse W, Trzaskoma B, Oılachi TA, Rosén K, Chipps BE, et al. A randomized multicenter study eva." 'ating Xolair persistence of response after long-term therapy. J Allergy Clin Immu 1c.. 2917;140(1):162-169.e2.

251. Ferguson GT, FitzGerald J.M, bleecker ER, Laviolette M, Bernstein D, LaForce C, et al. Benralizumab for pai $n$ ts with mild to moderate, persistent asthma (BISE): a randomised, double-blin' placebo-controlled, phase 3 trial. Lancet Respir Med. 2017;5(7):568-76.

252. Shimoda T, Odaj: ' $\mathfrak{a}$ H, Okamasa A, Kawase M, Komatsubara M, Mayer B, et al. Efficacy and safetv of mepolizumab in Japanese patients with severe eosinophilic asthma. Allergol Int Off J Jpn Soc Allergol. 2017;66(3):445-51.

253. Koshak A, Wei L, Koshak E, Wali S, Alamoudi O, Demerdash A, et al. Nigella sativa Supplementation Improves Asthma Control and Biomarkers: A Randomized, DoubleBlind, Placebo-Controlled Trial. Phytother Res PTR. 2017;31(3):403-9.

254. Oishi K, Hirano T, Suetake R, Ohata S, Yamaji Y, Ito K, et al. A trial of oral corticosteroids for persistent systemic and airway inflammation in severe asthma. Immun Inflamm Dis. 2017;5(3):261-4.

255. Bjerregaard A, Laing IA, Backer V, Sverrild A, Khoo S-K, Chidlow G, et al. High fractional exhaled nitric oxide and sputum eosinophils are associated with an increased risk of future virus-induced exacerbations: A prospective cohort study. Clin Exp Allergy J Br Soc Allergy Clin Immunol. 2017;47(8):1007-13. 
256. Ortega HG, Yancey SW, Mayer B, Gunsoy NB, Keene ON, Bleecker ER, et al. Severe eosinophilic asthma treated with mepolizumab stratified by baseline eosinophil thresholds: a secondary analysis of the DREAM and MENSA studies. Lancet Respir Med. 2016;4(7):549-56.

257. Wenzel S, Castro M, Corren J, Maspero J, Wang L, Zhang B, et al. Dupilumab efficacy and safety in adults with uncontrolled persistent asthma despite use of medium-to-high-dose inhaled corticosteroids plus a long-acting $\beta 2$ agonist: a randomised double-blind placebo-controlled pivotal phase $2 \mathrm{~b}$ dose-ranging trial. Lancet Lond Engl. 2016;388(10039):31-44.

258. Fitzpatrick AM, Jackson DJ, Mauger DT, Boehmer SJ, Phipatanakul W, Sheehan WJ, et al. Individualized Therapy for Persistent Asthma in Young Children. J Allergy Clin Immunol. 2016;138(6):1608-1618.e12.

259. Hanania NA, Korenblat P, Chapman KR, Bateman ED Ko, recky P, Paggiaro P, et al. Efficacy and safety of lebrikizumab in patients with …ncu.rolled asthma (LAVOLTA I and LAVOLTA II): replicate, phase 3, randomisec do ible-blind, placebo-controlled trials. Lancet Respir Med. 2016;4(10):781-96.

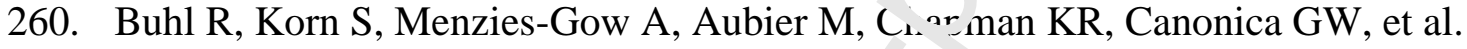
Assessing biomarkers in a real-world severe asthma study (ARIETTA). Respir Med. 2016;115:7-12.

261. Tuomisto LE, Ilmarinen P, Nieme' ${ }_{\mathfrak{A}} \mathrm{C}$ Hàinpää J, Kankaanranta T, Kankaanranta H. A 12-year prognosis of adult-onset . thma: Seinäjoki Adult Asthma Study. Respir Med. 2016;117:223-9.

262. Westerhof GA, de Groot JC, / me ak M, de Nijs SB, Ten Brinke A, Weersink EJ, et al. Predictors of frequent exac _atiuns in (ex)smoking and never smoking adults with severe asthma. Respir Meu. 2016;118:122-7.

263. Park H-S, Kim M-K. Ima N N, Nakanishi T, Adachi M, Ohta K, et al. A Phase 2a Study of Benralizumab for $\mathrm{Pa}_{\mathrm{a}}^{\text {: }}$-nts with Eosinophilic Asthma in South Korea and Japan. Int Arch Allergy Imn uno . 2016;169(3):135-45.

264. Busse WW, Holrat: ST, Wenzel SW, Klekotka P, Chon Y, Feng J, et al. Biomarker Profiles in Asthma With High vs Low Airway Reversibility and Poor Disease Control. Chest. 2015;148(6):1489-96.

265. Tagaya E, Kondo M, Kirishi S, Kawagoe M, Kubota N, Tamaoki J. Effects of regular treatment with combination of salmeterol/fluticasone propionate and salmeterol alone in cough variant asthma. J Asthma Off J Assoc Care Asthma. 2015;52(5):512-8.

266. Ortega HG, Liu MC, Pavord ID, Brusselle GG, FitzGerald JM, Chetta A, et al. Mepolizumab Treatment in Patients with Severe Eosinophilic Asthma. N Engl J Med. 2014;371(13):1198-207.

267. Liu W, Chu J, Sun L, Shen Z, Liu Y, Peng Q, et al. Effect of age and eosinophil number on fractional exhaled nitric oxide level in non-asthmatic children in shanghai. Iran J Allergy Asthma Immunol. 2014;13(5):343-7. 
268. Castro M, Wenzel SE, Bleecker ER, Pizzichini E, Kuna P, Busse WW, et al. Benralizumab, an anti-interleukin 5 receptor $\alpha$ monoclonal antibody, versus placebo for uncontrolled eosinophilic asthma: a phase $2 \mathrm{~b}$ randomised dose-ranging study. Lancet Respir Med. 2014;2(11):879-90.

269. Pettipher R, Hunter MG, Perkins CM, Collins LP, Lewis T, Baillet M, et al. Heightened response of eosinophilic asthmatic patients to the CRTH2 antagonist OC000459. Allergy. 2014;69(9):1223-32.

270. Ortega H, Li H, Suruki R, Albers F, Gordon D, Yancey S. Cluster analysis and characterization of response to mepolizumab. A step closer to personalized medicine for patients with severe asthma. Ann Am Thorac Soc. 2014;11(7):1011-7.

271. Steinke JW, Negri J, Payne SC, Borish L. Biological Eff ects of Leukotriene E4 on Eosinophils. Prostaglandins Leukot Essent Fatty Acids. 2v:1;91(3):105-10.

272. Kupczyk M, Dahlén B, Sterk PJ, Nizankowska-Mogiln $\iota^{1}{ }^{\cdots}$. E, Papi A, Bel EH, et al. Stability of phenotypes defined by physiological va iabl s and biomarkers in adults with asthma. Allergy. 2014;69(9):1198-204.

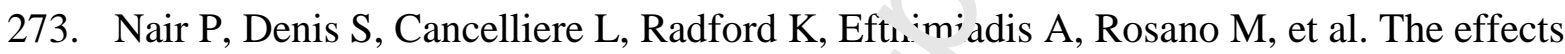
of an epithelial barrier protective cationic aerc sol uì allergen-induced airway inflammation in asthma: a randomized, p ar tt o-controlled clinical trial. Clin Exp Allergy J Br Soc Allergy Clin Immuno' 2vit;44(9):1200-3.

274. Hanania NA, Wenzel S, Rosén K, 'T' ‘eh H-J, Mosesova S, Choy DF, et al. Exploring the effects of omalizumab in $a^{11}$ ergic asihma: an analysis of biomarkers in the EXTRA study. Am J Respir Crit Care Mec. 2013;187(8):804-11.

275. Brusselle GG, Vanderstich ${ }^{\prime}>C$, jordens P, Deman R, Slabbynck H, Ringoet V, et al. Azithromycin for prevent i $n$ of exacerbations in severe asthma (AZISAST): a multicentre randomised i ubie-blind placebo-controlled trial. Thorax. 2013;68(4):322-9.

276. Samary C dos S,, ntu es MA, Silva JD, Silva da AL, Araújo de CC, Bakker-Abreu I, et al. Impact of $\mathrm{L}$ cluus Calmette-Guérin Moreau vaccine on lung remodeling in experimental asthrr a. Respir Physiol Neurobiol. 2013;189(3):614-23.

277. Kupczyk M, Haque S, Middelveld RJM, Dahlén B, Dahlén S-E, Investigators B. Phenotypic predictors of response to oral glucocorticosteroids in severe asthma. Respir Med. 2013;107(10):1521-30.

278. McGrath KW, Icitovic N, Boushey HA, Lazarus SC, Sutherland ER, Chinchilli VM, et al. A large subgroup of mild-to-moderate asthma is persistently noneosinophilic. Am J Respir Crit Care Med. 2012;185(6):612-9.

279. Ricciardolo FLM, Di Stefano A, Silvestri M, Van Schadewijk AM, Malerba M, Hiemstra PS, et al. Exhaled nitric oxide is related to bronchial eosinophilia and airway hyperresponsiveness to bradykinin in allergen-induced asthma exacerbation. Int J Immunopathol Pharmacol. 2012;25(1):175-82. 
280. Mendes FAR, Almeida FM, Cukier A, Stelmach R, Jacob-Filho W, Martins MA, et al. Effects of aerobic training on airway inflammation in asthmatic patients. Med Sci Sports Exerc. 2011;43(2):197-203.

281. Vaickus LJ, Bouchard J, Kim J, Natarajan S, Remick DG. Oral tolerance inhibits pulmonary eosinophilia in a cockroach allergen induced model of asthma: a randomized laboratory study. Respir Res. 2010;11:160-160.

282. Maneechotesuwan K, Ekjiratrakul W, Kasetsinsombat K, Wongkajornsilp A, Barnes PJ. Statins enhance the anti-inflammatory effects of inhaled corticosteroids in asthmatic patients through increased induction of indoleamine 2, 3-dioxygenase. $\mathbf{J}$ Allergy Clin Immunol. 2010;126(4):754-762.e1.

283. Lee SH, Lee J-H, Yoon HI, Park HY, Kim T-H, Yoo KF, et al. Change in inhaled corticosteroid treatment and COPD exacerbations: an analy is of real-world data from the KOLD/KOCOSS cohorts. Respir Res. 2019;20(1):( 2-c?.

284. George L, Wright A, Mistry V, Sutcliffe A, Chachi ', H lldar K, et al. Sputum Streptococcus pneumoniae is reduced in COPD $\mathrm{f}^{\prime}$ 'lowing treatment with benralizumab. Int J Chron Obstruct Pulmon Dis. 2019;14:117'i-i ?.

285. Bafadhel M, Peterson S, De Blas MA, Calver'ey PıI, Rennard SI, Richter K, et al. Predictors of exacerbation risk and respor $s f t$ budesonide in patients with chronic obstructive pulmonary disease: a post- $\mathrm{K} \cdot \mathrm{c}$ andlysis of three randomised trials. Lancet Respir Med. 2018;6(2):117-26.

286. Suissa S, Dell'Aniello S, Ernst P. Comıarative effectiveness of LABA-ICS versus LAMA as initial treatment in CO' ${ }^{\top}$ targeted by blood eosinophils: a population-based cohort study. Lancet Respir $\Lambda$ 'e'^. 2018;6(11):855-62.

287. Shute JK, Calzetta L, Carc. ci V, di Toro S, Page CP, Cazzola M. Inhaled nebulised unfractionated heparin i, nroves lung function in moderate to very severe COPD: A pilot study. Pulm Pharma ol Ther. 2018;48:88-96.

288. Rabe KF, Watz H Bar aldo S, Pedersen F, Biondini D, Bagul N, et al. Antiinflammatory etı - ts of roflumilast in chronic obstructive pulmonary disease (ROBERT): a 16-w eek, randomised, placebo-controlled trial. Lancet Respir Med. 2018;6(11):827-36.

289. Roche N, Chapman KR, Vogelmeier CF, Herth FJF, Thach C, Fogel R, et al. Blood Eosinophils and Response to Maintenance Chronic Obstructive Pulmonary Disease Treatment. Data from the FLAME Trial. Am J Respir Crit Care Med. 2017;195(9):1189-97.

290. Contoli M, Pauletti A, Rossi MR, Spanevello A, Casolari P, Marcellini A, et al. Longterm effects of inhaled corticosteroids on sputum bacterial and viral loads in COPD. Eur Respir J. 2017;50(4).

291. Papi A, Dokic D, Tzimas W, Mészáros I, Olech-Cudzik A, Koroknai Z, et al. Fluticasone propionate/formoterol for COPD management: a randomized controlled trial. Int J Chron Obstruct Pulmon Dis. 2017;12:1961-71. 
292. Dasgupta A, Kjarsgaard M, Capaldi D, Radford K, Aleman F, Boylan C, et al. A pilot randomised clinical trial of mepolizumab in COPD with eosinophilic bronchitis. Eur Respir J [Internet]. 2017 Mar;49(3). Available from: https://erj.ersjournals.com/content/49/3/1602486

293. Sivapalan P, Moberg M, Eklöf J, Janner J, Vestbo J, Laub RR, et al. A multi-center randomized, controlled, open-label trial evaluating the effects of eosinophil-guided corticosteroid-sparing therapy in hospitalised patients with COPD exacerbations - The CORTICO steroid reduction in COPD (CORTICO-COP) study protocol. BMC Pulm Med. 2017;17(1):114-114.

294. Pascoe S, Costa M, Marks-Konczalik J, McKie E, Yang S, Scherbovsky PS. Biological effects of p38 MAPK inhibitor losmapimod does not translate to clinical benefits in COPD. Respir Med. 2017;130:20-6.

295. Wedzicha JA, Banerji D, Chapman KR, Vestbo J, Roc! e N Ayers RT, et al.

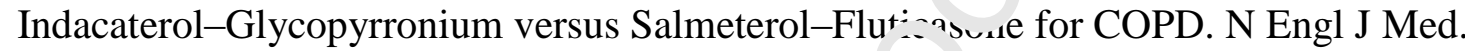
2016;374(23):2222-34.

296. Barnes NC, Sharma R, Lettis S, Calverley PM 1. L'ood eosinophils as a marker of response to inhaled corticosteroids in COPD. Eu ${ }^{*}$ r.espir J. 2016;47(5):1374-82.

297. Hinds DR, DiSantostefano RL, Le HV, P s $\mathrm{O}$ S. Identification of responders to inhaled corticosteroids in a chronic obs ucuve pulmonary disease population using cluster analysis. BMJ Open. 2016: $>(6: \mathrm{e} 0,0099-\mathrm{e} 010099$.

298. Marks-Konczalik J, Costa M, Pobertsun J, McKie E, Yang S, Pascoe S. A post-hoc subgroup analysis of data from a $\triangle$ : $x$ month clinical trial comparing the efficacy and safety of losmapimod in mod ro it severe COPD patients with $\leq 2 \%$ and $>2 \%$ blood eosinophils. Respir Med. 2r: $5 ;$ ív9(7):860-9.

299. Bafadhel M, McKenna S, Terry S, Mistry V, Pancholi M, Venge P, et al. Blood eosinophils to direct cori - osteroid treatment of exacerbations of chronic obstructive

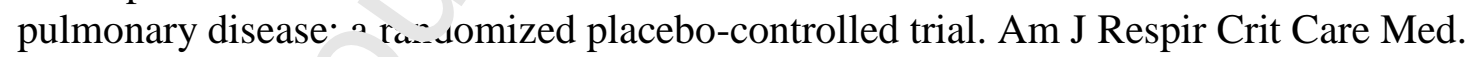
2012;186(1):4Q-5 ?.

300. de Nijs SB, Fens N, Lutter R, Dijkers E, Krouwels FH, Smids-Dierdorp BS, et al. Airway inflammation and mannitol challenge test in COPD. Respir Res.

2011;12(1):11-11.

301. Hirano I, Collins MH, Assouline-Dayan Y, Evans L, Gupta S, Schoepfer AM, et al. RPC4046, a Monoclonal Antibody Against IL13, Reduces Histologic and Endoscopic Activity in Patients With Eosinophilic Esophagitis. Gastroenterology. 2019;156(3):592-603.e10.

302. de Ruiter K, Tahapary DL, Sartono E, Nutman TB, Smit JWA, Koenderman L, et al. The Effect of Helminths on Granulocyte Activation: A Cluster-Randomized PlaceboControlled Trial in Indonesia. J Infect Dis. 2019;219(9):1474-82.

303. Johnson K, Iyer V, Katzka D, Ravi K, Lennon R, Pendegraft R, et al. Poor Relationship Between Fractionated Exhaled Nitric Oxide and Disease Activity in Eosinophilic Esophagitis. Dysphagia. 2019;34(1):138-44. 
304. Kanagalingam S, Shehab SS, Kaminsky DA, Wise RA, Lang JE, Dixon AE. Effect of obesity on sinonasal disease in asthma. J Asthma Off J Assoc Care Asthma.

2018;55(5):525-31.

305. Wechsler ME, Akuthota P, Jayne D, Khoury P, Klion A, Langford CA, et al. Mepolizumab or Placebo for Eosinophilic Granulomatosis with Polyangiitis. N Engl J Med. 2017;376(20):1921-32.

306. Bachert C, Sousa AR, Lund VJ, Scadding GK, Gevaert P, Nasser S, et al. Reduced need for surgery in severe nasal polyposis with mepolizumab: Randomized trial. J Allergy Clin Immunol. 2017;140(4):1024-1031.e14.

307. Jerschow E, Edin ML, Pelletier T, Abuzeid WM, Akbar NA, Gibber M, et al. Plasma 15-Hydroxyeicosatetraenoic Acid Predicts Treatment Oı tcomes in Aspirin-

Exacerbated Respiratory Disease. J Allergy Clin Immunol ?ract. 2017;5(4):9981007.e2.

308. Eastman JJ, Cavagnero KJ, Deconde AS, Kim AS . Karti MR, Broide DH, et al. Group 2 innate lymphoid cells are recruited to the nasal - ucosa in patients with aspirinexacerbated respiratory disease. J Allergy Clin $\mathbf{m}_{\mathrm{m}}$ unol. 2017;140(1):101-108.e3.

309. Liu T, Kanaoka Y, Barrett NA, Feng C, Garofalo L, Lai J, et al. ,Aspirin-exacerbated respiratory disease involves a cysteinyl le $\mathrm{k} \mathrm{ot}$ iene-driven IL-33-mediated mast cell activation pathway. J Immunol Baltim \Id ij50. 2015;195(8):3537-45.

310. Oyama Y, Fujisawa T, Hashimoto ? Enomoto N, Nakamura Y, Inui N, et al. Efficacy of short-term prednisolone tre ${ }^{\star}$ ment 11 patients with chronic eosinophilic pneumonia. Eur Respir J. 2015;45(6):1624-31.

311. Steinke JW, Negri J, Liu L `רy - SC, Borish L. Aspirin Activation of Eosinophils and Mast Cells: Implications $i_{1}$, the Pathogenesis of Aspirin-Exacerbated Respiratory Disease. J Immunol Balı. $\eta$ Md 1950. 2014;193(1):41-7.

312. Choi G-S, Kim J-H S S in Y-S, Ye Y-M, Kim S-H, Park H-S. Eosinophil activation and novel mediators il the aspirin-induced nasal response in AERD. Clin Exp Allergy $\mathrm{J} \mathrm{Br}$ Soc Allergy Clinı 'muınol. 2013;43(7):730-40.

313. Spergel JM, Rothenberg ME, Collins MH, Furuta GT, Markowitz JE, Fuchs G, et al. Reslizumab in children and adolescents with eosinophilic esophagitis: results of a double-blind, randomized, placebo-controlled trial. J Allergy Clin Immunol. 2012;129(2):456-63, 463.e1-3.

314. Cai C, He M, Zhong S, Tang Y, Sun B, Chen Q, et al. Add-on montelukast vs doubledose budesonide in nonasthmatic eosinophilic bronchitis: a pilot study. Respir Med. 2012;106(10):1369-75.

315. Uller L, Ahlström Emanuelsson C, Andersson M, Erjefält JS, Greiff L, Persson CG. Early phase resolution of mucosal eosinophilic inflammation in allergic rhinitis. Respir Res. 2010;11(1):54-54. 
316. Kim C-K, Choi J, Kim HB, Callaway Z, Shin BM, Kim J-T, et al. A randomized intervention of montelukast for post-bronchiolitis: effect on eosinophil degranulation. $\mathrm{J}$ Pediatr. 2010;156(5):749-54.

317. Sahota J, Robinson DS. Update on new biologics for intractable eosinophilic asthma: impact of reslizumab. Drug Des Devel Ther. 2018 May 8;12:1173-81.

318. Pavord ID, Chanez P, Criner GJ, Kerstjens HAM, Korn S, Lugogo N, et al. Mepolizumab for Eosinophilic Chronic Obstructive Pulmonary Disease. N Engl J Med. 2017 26;377(17):1613-29. 
Figure 1: Schematic representation of surface receptors and immunological moieties of eosinophils. Eosinophils are bi-lobed, multi-functional innate immune cells with diverse cell surface receptors, including those crucial for chemotaxis, cell adhesion, activation (via cytokine/growth factors), lipid mediation, and immune modulation (CD40/80/86/siglec8/Fc/MHC class-II). Eosinophils also comprise of a variety of intracellular functional moieties, such as lipid bodies and granules that play a key role in immune regulation and eosinophil functionality.

Abbreviations: PR - Pattern recognition receptors; MBP - Major basic protein; EPX Eosinophil peroxidase; MHC - Major histocompatibility complex; CD - Cluster of differentiation; CCR - CC-chemokine receptor; CXCR - CXC-chemokine receptor; FPR Formyl peptide receptor; C5aR - Complement component 5a receptor; C3aR - Complement component 3a receptor; LFA-1 - Lymphocyte function-a sociated antigen 1; CR Complement receptor; LTC4 - Leukotriene C4; LTE4 - Lf un triene E4; Leukotriene D4; PAF - Platelet-activating factor; PAR - Protease activate. eceptor; PAFR - Plateletactivating factor receptor; CRTH2 - Chemoattractaı ${ }^{t}$ r ceptor-homologous molecule expressed on T-helper type 2 cells; DP1 - Prostagland11. D2 receptor 1; EP4 - Prostaglandin E2 receptor 4; $\mathrm{LTB}_{4}$ - Leukotriene B4

Figure 2: Pathophysiology of eosinophi's a a thma Abbreviations: IL (Interleukin); TSLP (thymic stromal lymphopoietin); , Dr (Antigen-presenting cell); Th0 (naïve T-cell); Th2 (T-helper type 2 cells); MBP (Major bas : protein); EPO (Eosinophil peroxidase); ECP (Eosinophil cationic protein); EDN (Eu inophil-derived neurotoxin); NGF (Nerve growth factor); SCF (Stem cell factor); ASN 11 irway smooth muscle); AHR (Airway hyperresponsiveness); TGF- $\beta$ (Tr $\sim$ sst $`$ ning growth factor beta); ECM (Extracellular matrix)

Figure 3: Pathophysiolog of osinophil on COPD Abbreviations: CPE - Cytopathogenic effect; $\mathrm{CD} 4^{+} \mathrm{TH} 2-\mathrm{CD}^{4}$ i helper 2 cells; IL - Interleukin; PAF - Platelet activating factor; MBP - Major basic pr tt: $n \cdot$ EPO - Eosinophil peroxidase; ECP - Eosinophil cationic protein

\section{Figure 4: Current drugs acting on eosinophils}

Abbreviations: IL (Interleukin); TSLP (thymic stromal lymphopoietin); Th0 (naïve T-cell); Th2 (T-helper type 2 cells); ILC2 (Type 2 innate lymphoid cells); IL-5R $\alpha$ (Interleukin-5 receptor alpha); CRTH2 (chemoattractant receptor-homologous molecule expressed on Th2 cells); PGD2 (Prostaglandin D2); GM-CSF (Granulocyte-macrophage colony-stimulating factor); IL-4R $\alpha$ (Interleukin-4 receptor alpha); IgE (Immunoglobulin E); FceRI (Highaffinity immunoglobin E receptor); DC (Dendritic cell) 
Table 1: List of clinical trials on eosinophils for asthma

\begin{tabular}{|c|c|c|c|c|c|}
\hline $\begin{array}{l}\text { S. } \\
\mathbf{N} \\
\mathbf{0}\end{array}$ & Intervention & $\begin{array}{c}\text { No. of } \\
\text { recruitments/Country/Pha } \\
\text { se of } \\
\text { study/Ongoing/cancelled }\end{array}$ & Area of trial & Sponsor & Ref \\
\hline 1. & Saffron & 86/Phase 1/Iran/Ongoing & $\begin{array}{l}\text { Effect on } \\
\text { allergic asthma } \\
\text { patient's } \\
\text { clinical } \\
\text { symptoms, } \\
\text { blood pressure, } \\
\text { lipid panels, } \\
\text { basophils nd } \\
\text { eosinophilr } \\
\text { receiving } \\
\text { saffror } \\
\text { supp el. }{ }_{\text {. }} \text { iatio } \\
\text { n. }\end{array}$ & $\begin{array}{l}\text { Ahvaz- } \\
\text { Jundishapur } \\
\text { university of } \\
\text { medical } \\
\text { sciences }\end{array}$ & $\begin{array}{l}(238 \\
)^{2}\end{array}$ \\
\hline 2. & $\begin{array}{l}\text { Mepolizuma } \\
\text { b }\end{array}$ & 32/Japan & $\begin{array}{l}\Gamma \text { alu ition of } \\
\text { rep 'izumab's } \\
\text { efficacy and } \\
\text { afety in severe } \\
\text { eosinophilic } \\
\text { asthma patients } \\
\text { receiving } \\
\text { treatment with } \\
\text { it long-term. }\end{array}$ & Sutoh Hospital & $\begin{array}{l}(239 \\
)\end{array}$ \\
\hline 3. & Vitamin D & 86/Mexico & $\begin{array}{l}\text { Evaluation of } \\
\text { vitamin D's } \\
\text { effect as a } \\
\text { supplement on } \\
\text { the pathogenic } \\
\text { bacteria } \\
\text { colonization in } \\
\text { the upper } \\
\text { respiratory tract } \\
\text { of patients with } \\
\text { allergic asthma. }\end{array}$ & $\begin{array}{l}\text { General } \\
\text { Hospital of } \\
\text { Mexico }\end{array}$ & $\begin{array}{l}(240 \\
)\end{array}$ \\
\hline 4 & $\begin{array}{l}\text { Benralizuma } \\
\text { b }\end{array}$ & 2681/Phase III/Completed & $\begin{array}{l}\text { Effects of } \\
\text { baseline factors } \\
\text { of patients with } \\
\text { severe asthma } \\
\text { on the efficacy } \\
\text { of } \\
\text { benralizumab. }\end{array}$ & AstraZeneca & $\begin{array}{l}(241 \\
)\end{array}$ \\
\hline 5 & $\begin{array}{l}\text { Benralizuma } \\
\text { b }\end{array}$ & 2508/Phase III/Completed & $\begin{array}{l}\text { Efficacy of } \\
\text { benralizumab } \\
\text { based on atopic } \\
\text { status and } \\
\text { serum }\end{array}$ & AstraZeneca & $\begin{array}{l}(242 \\
)^{2}\end{array}$ \\
\hline
\end{tabular}




\begin{tabular}{|c|c|c|c|c|c|}
\hline & & & $\begin{array}{l}\text { concentrations } \\
\text { of } \operatorname{IgE} \text {. }\end{array}$ & & \\
\hline 6 & Fevipiprant & $\begin{array}{l}\text { 61/Phase II/United } \\
\text { Kingdom/ Completed }\end{array}$ & $\begin{array}{l}\text { Potential } \\
\text { reduction of } \\
\text { eosinophilic } \\
\text { airway } \\
\text { inflammation in } \\
\text { moderate-to- } \\
\text { severe } \\
\text { eosinophilic } \\
\text { asthma } \\
\text { receiving } \\
\text { fevipiprant } \\
\text { (QAW039). }\end{array}$ & $\begin{array}{l}\text { Novartis } \\
\text { Pharmaceuticals }\end{array}$ & $\begin{array}{l}\text { (111 } \\
)^{2}\end{array}$ \\
\hline 7 & $\begin{array}{l}\text { Mepolizuma } \\
\text { b }\end{array}$ & 651/Phase III/Completed & 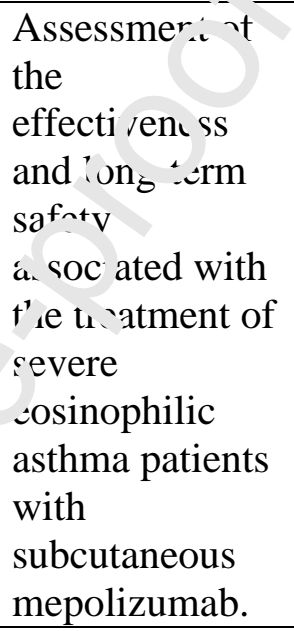 & $\begin{array}{l}\text { GlaxoSmithKli } \\
\text { ne }\end{array}$ & $\begin{array}{l}(243 \\
)\end{array}$ \\
\hline 8 & $\begin{array}{l}\text { Induced } \\
\text { sputum }\end{array}$ & $\begin{array}{l}\text { 300/Multiple } \\
\text { countries/Ph } / \mathrm{Ph}_{\mu} \\
\text { III/Comple } 4 \text { - }\end{array}$ & $\begin{array}{l}\text { Comparison of } \\
\text { different gene } \\
\text { and protein } \\
\text { expression in } \\
\text { sputum samples } \\
\text { of severe } \\
\text { asthma and } \\
\text { non-smoking } \\
\text { mild/moderate } \\
\text { asthma patients }\end{array}$ & $\begin{array}{l}\text { Academisch } \\
\text { Medisch } \\
\text { Centrum - } \\
\text { Universiteit van } \\
\text { Amsterdam } \\
\text { (AMC-UvA) }\end{array}$ & $\begin{array}{l}\text { (244 } \\
\text { ) }\end{array}$ \\
\hline 9 & Omalizumab & $\begin{array}{l}\text { 1071/USA/Phase } \\
\text { III/Completed }\end{array}$ & $\begin{array}{l}\text { Evaluation of } \\
\text { factors } \\
\text { associated with } \\
\text { the prediction } \\
\text { of response to } \\
\text { omalizumab for } \\
\text { the purpose of } \\
\text { identifying } \\
\text { patients with } \\
\text { highest } \\
\text { potential to } \\
\text { attain greatest } \\
\text { clinical }\end{array}$ & - & $\begin{array}{l}(245 \\
)\end{array}$ \\
\hline
\end{tabular}




\begin{tabular}{|c|c|c|c|c|c|}
\hline & & & $\begin{array}{l}\text { advantage from } \\
\text { treatment. }\end{array}$ & & \\
\hline 12 & $\begin{array}{l}\text { Mepolizuma } \\
\mathrm{b}\end{array}$ & $\begin{array}{l}\text { 621/Multiple } \\
\text { countries/Phase } \\
\text { II/Completed }\end{array}$ & $\begin{array}{l}\text { Association of } \\
\text { asthma } \\
\text { exacerbations } \\
\text { with enhanced } \\
\text { decline in lung } \\
\text { function. }\end{array}$ & $\begin{array}{l}\text { GlaxoSmithKli } \\
\text { ne }\end{array}$ & $\begin{array}{l}(246 \\
)\end{array}$ \\
\hline 13 & $\begin{array}{l}\text { Tiotropium } \\
\text { Respimat }\end{array}$ & $\begin{array}{l}\text { 459/Multiple } \\
\text { countries/Phase } \\
\text { III/Completed }\end{array}$ & $\begin{array}{l}\text { Influence of T2 } \\
\text { status on } \\
\text { responses to } \\
\text { tiotropium } \\
\text { Respimat add- } \\
\text { on therapy. }\end{array}$ & $\begin{array}{l}\text { Boehringer } \\
\text { Ingelheim }\end{array}$ & $\begin{array}{l}(247 \\
)\end{array}$ \\
\hline 14 & $\begin{array}{l}\text { Mepolizuma } \\
\mathrm{b}\end{array}$ & $\begin{array}{l}\text { 556/Multiple } \\
\text { countries/Phase } \\
\text { III/Completed }\end{array}$ & 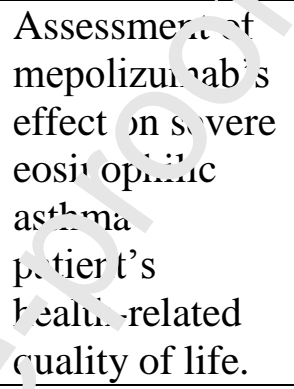 & $\begin{array}{l}\text { GlaxoSmithKli } \\
\text { ne }\end{array}$ & $\begin{array}{l}(248 \\
)\end{array}$ \\
\hline 15 & - & $\begin{array}{l}\text { 120/USA/Phase I/Ongoirg } \\
\text { (Suspensed) }\end{array}$ & $\begin{array}{l}\text { Description of } \\
\text { exacerbation- } \\
\text { prone asthma's } \\
\text { clinical } \\
\text { features. }\end{array}$ & $\begin{array}{l}\text { University of } \\
\text { Wisconsin, } \\
\text { Madison }\end{array}$ & $\begin{array}{l}(249 \\
)\end{array}$ \\
\hline 16 & Omalizumab & 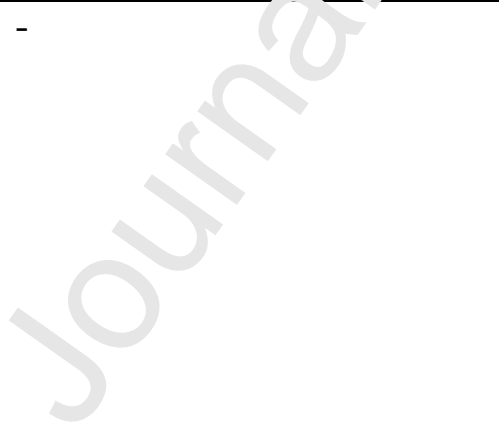 & $\begin{array}{l}\text { Benefit and } \\
\text { persistence of } \\
\text { response in } \\
\text { subjects } \\
\text { continuing or } \\
\text { withdrawing } \\
\text { from long-term } \\
\text { omalizumab } \\
\text { treatment. }\end{array}$ & - & $\begin{array}{l}(250 \\
)\end{array}$ \\
\hline 17 & $\begin{array}{l}\text { Benralizuma } \\
\text { b }\end{array}$ & $\begin{array}{l}\text { 211/Multiple } \\
\text { countries/Phase } \\
\text { III/Completed }\end{array}$ & $\begin{array}{l}\text { Assessment of } \\
\text { benralizumab } \\
\text { as a treatment } \\
\text { for mild-to- } \\
\text { moderate } \\
\text { persistent } \\
\text { asthma patients } \\
\text { in terms of its } \\
\text { safety and } \\
\text { efficacy. }\end{array}$ & AstraZeneca & $\begin{array}{l}(251 \\
)\end{array}$ \\
\hline 18 & $\begin{array}{l}\text { Mepolizuma } \\
\text { b }\end{array}$ & $\begin{array}{l}\text { 580/Japan/Phase } \\
\text { III/Completed }\end{array}$ & $\begin{array}{l}\text { Description of } \\
\text { mepolizumab's } \\
\text { safety and } \\
\text { efficacy in the }\end{array}$ & $\begin{array}{l}\text { GlaxoSmithKli } \\
\text { ne }\end{array}$ & $\begin{array}{l}(252 \\
)\end{array}$ \\
\hline
\end{tabular}




\begin{tabular}{|c|c|c|c|c|c|}
\hline & & & $\begin{array}{l}\text { treatment of } \\
\text { Japanese } \\
\text { patients with } \\
\text { severe } \\
\text { eosinophilic } \\
\text { asthma from } \\
\text { the MENSA } \\
\text { trial. }\end{array}$ & & \\
\hline 19 & $\begin{array}{l}\text { Nigella } \\
\text { sativa }\end{array}$ & $\begin{array}{l}\text { 80/Saudi Arabia/Phase } \\
\text { II/Completed }\end{array}$ & $\begin{array}{l}\text { Evaluation of } \\
\text { nigella sativa } \\
\text { oil benefits as a } \\
\text { supplement in } \\
\text { the treatment of } \\
\text { asthma bass } \\
\text { on clinica }{ }^{1} \text {-nd } \\
\text { inflamma. ory } \\
\text { param ter. }\end{array}$ & $\begin{array}{l}\text { University } \\
\text { College, } \\
\text { London }\end{array}$ & $\begin{array}{l}(253 \\
)\end{array}$ \\
\hline 20 & $\begin{array}{l}\text { Oral } \\
\text { corticosteroid } \\
\mathrm{S}\end{array}$ & $\begin{array}{l}\text { 20/Japan/Phase } \\
\text { 1/Completed }\end{array}$ & $\begin{array}{l}\text { Iden ifintion } \\
\text { of the } \\
\text { 1. 'atir nship } \\
\text { retwion } \\
\text { asthmatic } \\
\text { patients FeNO } \\
\text { levels and } \\
\text { blood } \\
\text { eosinophils. }\end{array}$ & $\begin{array}{l}\text { Japanese } \\
\text { Society for the } \\
\text { Promotion of } \\
\text { Science and } \\
\text { Wakayama } \\
\text { Medical Award } \\
\text { for Young } \\
\text { Researchers }\end{array}$ & $\begin{array}{l}(254 \\
)\end{array}$ \\
\hline 21 & - & 112/Phase I & $\begin{array}{l}\text { Assessment of } \\
\text { the relationship } \\
\text { between type } 2 \\
\text { inflammation } \\
\text { and risk of } \\
\text { virus-induced } \\
\text { asthma } \\
\text { exacerbations }\end{array}$ & $\begin{array}{l}\text { Bispebjerg } \\
\text { University } \\
\text { Hospital, the } \\
\text { University of } \\
\text { Copenhagen }\end{array}$ & $\begin{array}{l}(255 \\
)\end{array}$ \\
\hline 22 & $\begin{array}{l}\text { Mepolizuma } \\
\mathrm{b}\end{array}$ & $\begin{array}{l}58 .{ }^{\prime} \text { Multiple } \\
\text { cc } \cdots \text { cries/Phase } \\
\text { III/Completed }\end{array}$ & $\begin{array}{l}\text { Assessment } \\
\text { of the } \\
\text { relationship } \\
\text { of baseline } \\
\text { blood } \\
\text { eosinophil } \\
\text { counts and } \\
\text { mepolizum } \\
\text { ab's } \\
\text { efficacy. }\end{array}$ & $\begin{array}{l}\text { GlaxoSmithKli } \\
\text { ne }\end{array}$ & $\begin{array}{l}(256 \\
)\end{array}$ \\
\hline 23 & Dupilumab & $\begin{array}{l}\text { 776/Multile countries/Phase } \\
\text { II/Completed }\end{array}$ & $\begin{array}{l}\text { - Assessment } \\
\text { of } \\
\text { dupilumab' } \\
\text { s efficacy } \\
\text { and safety } \\
\text { aspects as }\end{array}$ & $\begin{array}{l}\text { Sanofi- } \\
\text { Genzyme and } \\
\text { Regeneron } \\
\text { Pharmaceuticals }\end{array}$ & $\begin{array}{l}(257 \\
)\end{array}$ \\
\hline
\end{tabular}




\begin{tabular}{|c|c|c|c|c|c|}
\hline & & & $\begin{array}{l}\text { an add-on } \\
\text { therapy in } \\
\text { uncontrolle } \\
\mathrm{d} \text { and } \\
\text { persistent } \\
\text { asthmatics } \\
\text { on medium- } \\
\text { to-high } \\
\text { doses of } \\
\text { ICS/LABA } \\
\text { therapy, } \\
\text { disregardin } \\
\text { g the } \\
\text { baselinc } \\
\text { eosino } \\
\text { count }\end{array}$ & & \\
\hline 24 & $\begin{array}{l}\text { Personalised } \\
\text { therapy }\end{array}$ & $\begin{array}{l}\text { 300/USA/Phase } \\
\text { III/Completed }\end{array}$ & $\begin{array}{l}\text { Persor allz tion } \\
\text { of as hi.- } \\
\text { themad }\end{array}$ & $\begin{array}{l}\text { Milton S. } \\
\text { Hershey } \\
\text { Medical Center }\end{array}$ & $\begin{array}{l}(258 \\
)\end{array}$ \\
\hline 25 & $\begin{array}{l}\text { Lebrikizuma } \\
\text { b }\end{array}$ & $\begin{array}{l}\text { 1068/Multiple } \\
\text { countries/Phase } \\
\text { II/Completed }\end{array}$ & $\begin{array}{l}\text { i bes ment of } \\
\text { ffficacy and } \\
\text { afety aspects } \\
\text { when used for } \\
\text { the treatment of } \\
\text { uncontrolled } \\
\text { asthmatics } \\
\text { despite ICS and } \\
\text { at least a } \\
\text { second } \\
\text { controller } \\
\text { medication. }\end{array}$ & $\begin{array}{l}\text { Hoffmann-La } \\
\text { Roche }\end{array}$ & $\begin{array}{l}(259 \\
)\end{array}$ \\
\hline 26 & - & $\begin{array}{l}\text { 483/M } 1 \text { il: } \\
\text { ou itrif s/Phase } \\
\text { IV, Tompleted }\end{array}$ & $\begin{array}{l}\text { Addressment of } \\
\text { unanswered } \\
\text { fundamental } \\
\text { queries } \\
\text { associated with } \\
\text { biomarkers of } \\
\text { asthma. } \\
\text { Assessment of } \\
\text { the relationship } \\
\text { between } \\
\text { biomarkers of } \\
\text { asthma and } \\
\text { health } \\
\text { outcomes } \\
\text { associated with } \\
\text { disease. }\end{array}$ & $\begin{array}{l}\text { Hoffmann-La } \\
\text { Roche }\end{array}$ & $\begin{array}{l}(260 \\
)\end{array}$ \\
\hline 27 & - & 259/Finland/Phase & Evaluation of & Seinajoki & $(261$ \\
\hline
\end{tabular}




\begin{tabular}{|c|c|c|c|c|c|}
\hline & & I/Completed & $\begin{array}{l}\text { the 12-year } \\
\text { prognosis in } \\
\text { patients who } \\
\text { develop asthma } \\
\text { as adults and } \\
\text { the aspects } \\
\text { related to its } \\
\text { prognosis. }\end{array}$ & Central Hospital & ) \\
\hline 28 & - & 571/Netherland & $\begin{array}{l}\text { Investigation of } \\
\text { factors related } \\
\text { to frequent } \\
\text { exacerbations } \\
\text { in non-smoker } \\
\text { asthma pats its } \\
\text { and asthm. } \\
\text { patients } \mathrm{i} \text { th : } \\
\text { histor: or } \\
\text { smol in. }\end{array}$ & $\begin{array}{l}\text { GlaxoSmithKli } \\
\text { ne }\end{array}$ & $\begin{array}{l}(262 \\
)\end{array}$ \\
\hline 29 & $\begin{array}{l}\text { Benralizuma } \\
\text { b }\end{array}$ & $\begin{array}{l}\text { 106/South Korea \& } \\
\text { Japan/Phase I/Completed }\end{array}$ & $\begin{array}{l}\text { Evalia ion of } \\
\text { l nra izumab's } \\
\text { effec. Is a } \\
\text { treatment of } \\
\text { uncontrolled } \\
\text { eosinophilic } \\
\text { asthma who } \\
\text { experienced 2-6 } \\
\text { exacerbations } \\
\text { in the previous } \\
\text { year and treated } \\
\text { with } \\
\text { medium/high } \\
\text { dosages of ICS } \\
\text { and LABA. }\end{array}$ & $\begin{array}{l}\text { MedImmune } \\
\text { LLC }\end{array}$ & $\begin{array}{l}(263 \\
)\end{array}$ \\
\hline 30 & - & $\begin{array}{l}{ }^{315} \bar{M} \mathrm{M} \text { tiple } \\
\text { cou 'tries/Phase } \\
\mathrm{II}^{\prime \sim} \mathrm{Jmpleted}\end{array}$ & $\begin{array}{l}\text { Comparison } \\
\text { between asthma } \\
\text { associated with } \\
\text { high and low } \\
\text { airway } \\
\text { reversibility in } \\
\text { terms of } \\
\text { function of } \\
\text { lungs, } \\
\text { biomarker } \\
\text { panel, and } \\
\text { control of } \\
\text { disease. }\end{array}$ & Amgen & $\begin{array}{l}(264 \\
)\end{array}$ \\
\hline 31 & SB010 & - & $\begin{array}{l}\text { Evaluation of } \\
\text { SB010 in terms } \\
\text { of its safety and } \\
\text { efficacy in the }\end{array}$ & - & )$^{(191}$ \\
\hline
\end{tabular}




\begin{tabular}{|c|c|c|c|c|c|}
\hline & & & $\begin{array}{l}\text { treatment of } \\
\text { allergic asthma } \\
\text { patients with } \\
\text { sputum } \\
\text { eosinophilia. }\end{array}$ & & \\
\hline 32 & $\begin{array}{l}\text { Salmeterol/ } \\
\text { fluticasone } \\
\text { propionate } \\
\text { Salmeterol }\end{array}$ & - & $\begin{array}{l}\text { Evaluation of } \\
\text { efficacy of } \\
\text { combination } \\
\text { therapy in the } \\
\text { treatment of } \\
\text { cough variant } \\
\text { asthma. }\end{array}$ & - & $\begin{array}{l}(265 \\
)\end{array}$ \\
\hline 33 & $\begin{array}{l}\text { Mepolizuma } \\
\mathrm{b}\end{array}$ & $\begin{array}{l}\text { 580/Multiple } \\
\text { countries/Phase } \\
\text { III/Completed }\end{array}$ & 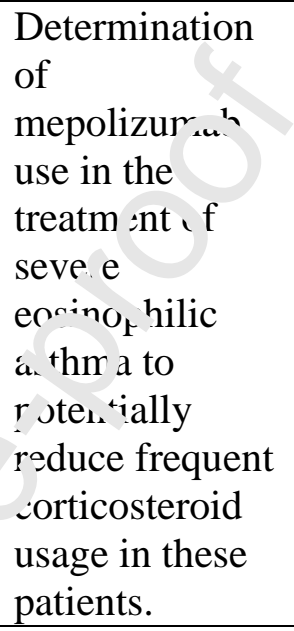 & $\begin{array}{l}\text { GlaxoSmithKli } \\
\text { ne }\end{array}$ & $\begin{array}{l}(266 \\
)\end{array}$ \\
\hline 34 & - & 132/China & $\begin{array}{l}\text { Identification } \\
\text { of the } \\
\text { association } \\
\text { between levels } \\
\text { of FeNO and } \\
\text { possible factors } \\
\text { in children } \\
\text { without asthma. }\end{array}$ & - & $\begin{array}{l}(267 \\
)\end{array}$ \\
\hline 35 & $\begin{array}{l}\text { Benralizuma } \\
\text { b }\end{array}$ & $\begin{array}{l}{ }^{964}{ }^{\prime} \mathrm{Mu} \text { tiple } \\
\text { cou } \cdot \text { tries/Phase } \\
\mathrm{IL}^{\prime}{ }^{\prime} \text { smpleted }\end{array}$ & $\begin{array}{l}\text { Assessment of } \\
\text { benralizumab's } \\
\text { in terms of its } \\
\text { effectiveness } \\
\text { and safety in } \\
\text { the treatment of } \\
\text { adult patients } \\
\text { with } \\
\text { uncontrolled } \\
\text { eosinophilic } \\
\text { asthma. }\end{array}$ & $\begin{array}{l}\text { MedImmune } \\
\text { LLC }\end{array}$ & $\begin{array}{l}(268 \\
)\end{array}$ \\
\hline 36 & OC000459 & $\begin{array}{l}\text { 40/United Kingdom/Phase } \\
\text { II/Completed }\end{array}$ & $\begin{array}{l}\text { Determination } \\
\text { of effect } \\
\text { associated with } \\
\text { lower doses of } \\
\text { OC00459 given } \\
\text { once daily. }\end{array}$ & $\begin{array}{l}\text { Chiesi } \\
\text { Farmaceutici } \\
\text { S.p.A. }\end{array}$ & $\begin{array}{l}(269 \\
)\end{array}$ \\
\hline
\end{tabular}




\begin{tabular}{|c|c|c|c|c|c|}
\hline & & & $\begin{array}{l}\text { Defined } \\
\text { phenotype of } \\
\text { patients with } \\
\text { highest } \\
\text { response to } \\
\text { OC00459 } \\
\text { treatment. }\end{array}$ & & \\
\hline 37 & $\begin{array}{l}\text { Mepolizuma } \\
\mathrm{b}\end{array}$ & $\begin{array}{l}\text { 621/Multiple } \\
\text { countries/Phase } \\
\text { II/Completed }\end{array}$ & 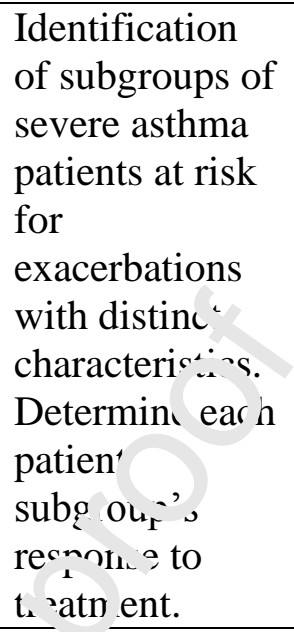 & $\begin{array}{l}\text { GlaxoSmithKli } \\
\text { ne }\end{array}$ & $\begin{array}{l}(270 \\
)\end{array}$ \\
\hline 38 & - & - & $\begin{array}{l}\text { J.1ves igation of } \\
\text { P2Y }_{12} \text { and } \\
\text { spr99 } \\
\text { expression by } \\
\text { eosinophils and } \\
\text { their LTE } \text { L }_{4} \\
\text { response } \\
\text { capacity. }\end{array}$ & $\begin{array}{l}\text { Merck } \\
\text { Pharmaceuticals }\end{array}$ & $\begin{array}{l}(271 \\
)\end{array}$ \\
\hline 39 & - & 169/Europe & $\begin{array}{l}\text { Assessment of } \\
\text { phenotype } \\
\text { stability based } \\
\text { on biomarkers } \\
\text { or } \\
\text { physiological } \\
\text { variables. }\end{array}$ & - & $\begin{array}{l}(272 \\
)\end{array}$ \\
\hline 40 & $\begin{array}{l}\text { Inhaled } \\
\text { cationic } \\
\text { airway lining } \\
\text { modulator }\end{array}$ & $-\infty$ & $\begin{array}{l}\text { Evaluation of } \\
\text { the role of } \\
\text { enhancing } \\
\text { epithelial } \\
\text { barrier in } \\
\text { reducing } \\
\text { inflammation } \\
\text { of the airway } \\
\text { due to inhaled } \\
\text { particles. }\end{array}$ & - & $\begin{array}{l}(273 \\
)\end{array}$ \\
\hline 41 & Omalizumab & $\begin{array}{l}\text { 850/Multiple } \\
\text { countries/Phase } \\
\text { III/Completed }\end{array}$ & $\begin{array}{l}\text { Assessment of } \\
\text { FeNO, } \\
\text { peripheral } \\
\text { blood }\end{array}$ & Genentech, Inc & $\begin{array}{l}(274 \\
)\end{array}$ \\
\hline
\end{tabular}




\begin{tabular}{|c|c|c|c|c|c|}
\hline & & & $\begin{array}{l}\text { eosinophils } \\
\text { count, and } \\
\text { serum periostin } \\
\text { as potential } \\
\text { biomarkers of } \\
\text { Th2 } \\
\text { inflammation } \\
\text { and potential } \\
\text { predictors of } \\
\text { omalizumab } \\
\text { treatment } \\
\text { outcomes. }\end{array}$ & & \\
\hline 42 & $\begin{array}{l}\text { Azithromyci } \\
\mathrm{n}\end{array}$ & $\begin{array}{l}\text { 109/Belgium/Phase } \\
\text { 4/Completed }\end{array}$ & $\begin{array}{l}\text { Benefit of } \\
\text { macrolides } \because \\
\text { neutrophil: } \\
\text { airway di ass. }\end{array}$ & $\begin{array}{l}\text { University } \\
\text { Hospital, Ghent }\end{array}$ & $\begin{array}{l}(275 \\
)\end{array}$ \\
\hline 43 & $\begin{array}{l}\text { Bacillus } \\
\text { Calmette- } \\
\text { Guérin } \\
\text { Moreau } \\
\text { vaccine } \\
\text { (BCG- } \\
\text { Moreau) }\end{array}$ & - & 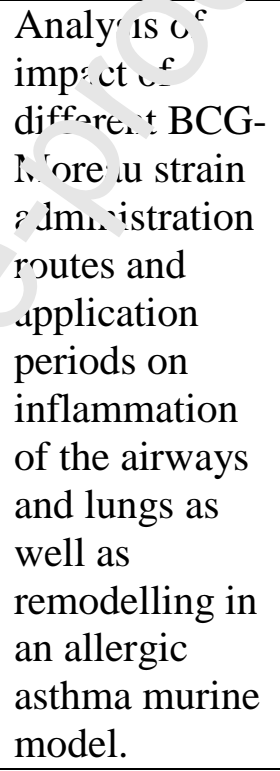 & - & $\begin{array}{l}(276 \\
)\end{array}$ \\
\hline 44 & $\begin{array}{l}\text { Oral } \\
\text { prednisolone }\end{array}$ & 233/Crve_ _n/NA/Active & $\begin{array}{l}\text { Assessment of } \\
\text { the practicality } \\
\text { to predict oral } \\
\text { prednisolone } \\
\text { response based } \\
\text { on patient's } \\
\text { medical } \\
\text { history, } \\
\text { physiological } \\
\text { variables and } \\
\text { biomarkers. }\end{array}$ & $\begin{array}{l}\text { Karolinska } \\
\text { Institutet }\end{array}$ & $\begin{array}{l}(277 \\
)\end{array}$ \\
\hline 45 & - & 0/USA/Phase 3/Withdarwn & $\begin{array}{l}\text { Determination } \\
\text { of non- } \\
\text { eosinophilic } \\
\text { asthma } \\
\text { phenotype's } \\
\text { prevalence and } \\
\text { clinical }\end{array}$ & $\begin{array}{l}\text { Milton S. } \\
\text { Hershey } \\
\text { Medical Center }\end{array}$ & )$^{(278}$ \\
\hline
\end{tabular}




\begin{tabular}{|c|c|c|c|c|c|}
\hline & & & features. & & \\
\hline 46 & Allergen & - & $\begin{array}{l}\text { Identification } \\
\text { that loss of } \\
\text { asthma control } \\
\text { is associated } \\
\text { with increased } \\
\text { eosinophilic } \\
\text { inflammation } \\
\text { of the airway } \\
\text { and airway } \\
\text { responsiveness } \\
\text { to bradykinin } \\
\text { due to exposure } \\
\text { to allergens } \\
\text { causing ex - lec } \\
\text { NO levels to } 1 \text { e } \\
\text { elevatr d }\end{array}$ & - & $\begin{array}{l}(279 \\
)\end{array}$ \\
\hline 47 & $\begin{array}{l}\text { Aerobic } \\
\text { training }\end{array}$ & 58/Brazil/Phase 3/Ongoing & $\begin{array}{l}\text { Eval taizic of } \\
\text { aem hlc training } \\
\text { t fect on } \\
\text { e ssil phil } \\
\text { inflammation } \\
\text { and nitric oxide } \\
\text { of moderate or } \\
\text { severe } \\
\text { persistent } \\
\text { asthma } \\
\text { patients. }\end{array}$ & $\begin{array}{l}\text { Instituto de } \\
\text { Investigação em } \\
\text { Imunologia }\end{array}$ & $\begin{array}{l}(280 \\
)\end{array}$ \\
\hline 48 & Allergen & 3 & $\begin{array}{l}\text { Examination of } \\
\text { potential to } \\
\text { ameliorate } \\
\text { asthma-like } \\
\text { pulmonary } \\
\text { inflammation } \\
\text { via induction of } \\
\text { oral tolerance } \\
\text { to cockroach } \\
\text { allergen. } \\
\text { Determination } \\
\text { of mechanisms } \\
\text { associated with } \\
\text { the } \\
\text { effectiveness of } \\
\text { oral tolerance. }\end{array}$ & - & $\begin{array}{l}(281 \\
)\end{array}$ \\
\hline 49 & Simvastatin & - & $\begin{array}{l}\text { Enhancement } \\
\text { of anti- } \\
\text { inflammatory } \\
\text { effects of } \\
\text { corticosteroids } \\
\text { by statins. }\end{array}$ & - & $\begin{array}{l}(282 \\
)\end{array}$ \\
\hline
\end{tabular}


Table 2: Clinical trials on essinophils actl. g in COPD

\begin{tabular}{|c|c|c|c|}
\hline S. No & Intervention & $\begin{array}{l}\text { No. of } \\
\text { recrv: } m_{i} \cdots \text { s/Country/Phase of } \\
\text { si idy/Ongoing/cancelled }\end{array}$ & Area of trial \\
\hline 1 & $\begin{array}{l}\text { Inhaled } \\
\text { corticosteroids } \\
\text { (ICS) }\end{array}$ & $114: \bar{\prime}$ 'Korea & $\begin{array}{l}\text { Evaluation of ICS prescription status accord } \\
\text { the revision of the } 2017 \text { GOLD guidelines }\end{array}$ \\
\hline 2 & Benralizumab & 29/Finland/Phase II & $\begin{array}{l}\text { Effect on bacterial load in the airways assoc } \\
\text { with the decline in eosinophilic airway } \\
\text { inflammation when treated with benralizum }\end{array}$ \\
\hline 3 & Budesonide & 1200/USA/Phase III/Completed & $\begin{array}{l}\text { Establishment of characteristics that determ } \\
\text { risk of exacerbation and clinical response to } \\
\text { treatment with ICS in COPD patients using } \\
\text { modelled continuous variable, eosinophil co }\end{array}$ \\
\hline 4 & $\begin{array}{l}\text { LABA-ICS/ } \\
\text { LAMA }\end{array}$ & 645/Germany/Completed & $\begin{array}{l}\text { Comparison of efficacy and safety of treatm } \\
\text { initiation guided by blood eosinophils with } \\
\text { LABA-ICS or LAMA in COPD patients. }\end{array}$ \\
\hline 5 & $\begin{array}{l}\text { Unfractionated } \\
\text { heparin }\end{array}$ & - & $\begin{array}{l}\text { Demonstration of improve lung function in } \\
\text { pulmonary rehabilitation COPD patients rec } \\
\text { unfractionated heparin. } \\
\text { Demonstration of the novel, safe and effecti } \\
\text { aspects of unfractionated heparin when used }\end{array}$ \\
\hline
\end{tabular}




\begin{tabular}{|c|c|c|c|}
\hline & & & treatment of COPD. \\
\hline 6 & Roflumilast & $\begin{array}{l}\text { 158/Multiple countries/Phase } \\
\text { III/Completed }\end{array}$ & $\begin{array}{l}\text { Assessment of roflumilast's anti-inflammat } \\
\text { effects on bronchial mucosal inflammation } \\
\text { moderate-to-severe COPD patients and chro } \\
\text { bronchitis patients }\end{array}$ \\
\hline 7 & $\begin{array}{l}\text { ICS-LABA } \\
\text { LABA-LAMA }\end{array}$ & $\begin{array}{l}\text { 3362/Multiple countries/Phase } \\
\text { III/completed }\end{array}$ & $\begin{array}{l}\text { Evaluation of blood eosinophil's value as a } \\
\text { predictor of responsiveness in the treatment } \\
\text { COPD exacerbations using ICS/LABA vers } \\
\text { LABA/LAMA therapy. }\end{array}$ \\
\hline 8 & $\begin{array}{l}\text { Salmeterol/Flu } \\
\text { ticasone } \\
\text { propionate } \\
\text { Salmeterol }\end{array}$ & 60/Italy/NA/Completed & $\begin{array}{l}\text { Determination of ICS effects on microbial l } \\
\text { airways of COPD patients. } \\
\text { Evaluation of the underlying inflammatory } \\
\text { mechanisms associated with the colonisation } \\
\text { microbiome of airways. }\end{array}$ \\
\hline 9 & $\begin{array}{l}\text { Fluticasone } \\
\text { propionate/ } \\
\text { formoterol }\end{array}$ & 0/NA/Phase III/Withdrawn & $\begin{array}{l}\text { Etiect of fluticasone propionate/formoterol } \\
\text { (.P/FORM) in COPD }\end{array}$ \\
\hline 10 & Mepolizumab & 19/Canada/Phase III/Comp' $\cdots{ }^{\prime} a$ & $\begin{array}{l}\text { Determination of mepolizumab's potential t } \\
\text { decrease percentage of sputum eosinophil in } \\
\text { cigarette smoke associated COPD patients } \\
\text { persistent sputum eosinophilia. } \\
\text { Assessment of mepolizumab's effects on cli } \\
\text { features of cigarette smoke associated COPI } \\
\text { patients with persistent sputum eosinophilia }\end{array}$ \\
\hline 11 & $\begin{array}{l}\text { Eosinophil- } \\
\text { guided } \\
\text { corticosteroid- } \\
\text { sparing } \\
\text { therapy }\end{array}$ & 318/Denm?rk/Phase IV/Completed & $\begin{array}{l}\text { Determination of potential reduction of syst } \\
\text { corticosteroid use in the treatment of AECO } \\
\text { without affecting the outcome. }\end{array}$ \\
\hline 12 & Losmapimod & $\begin{array}{l}\text { 72/U, ited Kingdom/Phase } \\
\text { I/Cumpleted }\end{array}$ & $\begin{array}{l}\text { Evaluation of exacerbation reduction by } \\
\text { losmapimod in moderate-to-severe COPD p }\end{array}$ \\
\hline 13 & $\begin{array}{l}\text { Indacaterol- } \\
\text { Glycopyrroniu } \\
\mathrm{m} \\
\text { Salmeterol- } \\
\text { Fluticasone }\end{array}$ & $\begin{array}{l}\text { 3362/Multiple countries/Phase } \\
\text { III/Completed }\end{array}$ & $\begin{array}{l}\text { Identification of the role of LABA-LAMA r } \\
\text { in COPD patients with at least one exacerba } \\
\text { the past year. }\end{array}$ \\
\hline 14 & $\begin{array}{l}\text { ICS } \\
\text { withdrawal }\end{array}$ & 444/Denmark/Phase IV/Ongoing & $\begin{array}{l}\text { Identification of relationship between baseli } \\
\text { blood eosinophil count and rate of lung func } \\
\text { decline. } \\
\text { Evaluation of risk/benefit ratio in COPD pat } \\
\text { receiving ICS therapy through the predictior } \\
\text { patient response to ICS using a biomarker }\end{array}$ \\
\hline 15 & $\begin{array}{l}\text { Fluticasone } \\
\text { furoate/vilanter } \\
\text { ol }\end{array}$ & $\begin{array}{l}\text { 1635/Multiple countries/Phase } \\
\text { III/Completed }\end{array}$ & $\begin{array}{l}\text { Identification of COPD patient clusters with } \\
\text { potential to attain benefit from ICS/LABA } \\
\text { treatment compared to LABA singularly. }\end{array}$ \\
\hline
\end{tabular}




\begin{tabular}{|c|c|c|c|}
\hline & Vilanterol & & Validation of COPD clusters identified in th \\
\hline 16 & Losmapimod & $\begin{array}{l}\text { 604/Multiple countries/Phase } \\
\text { II/Completed }\end{array}$ & $\begin{array}{l}\text { Analysis of losmapimod's effect as a treatm } \\
\text { reduce moderate/severe exacerbation rates i } \\
\text { subgroups of COPD patients with a baseline } \\
\text { and }>2 \% \text { blood eosinophils. }\end{array}$ \\
\hline 17 & Prednisolone & - & $\begin{array}{l}\text { Investigation of the functionality of blood } \\
\text { eosinophils in the direction of corticosteroid } \\
\text { treatment during COPD exacerbations. }\end{array}$ \\
\hline 18 & $\begin{array}{l}\text { Hypertonic } \\
\text { saline } \\
\text { Mannitol } \\
\text { challenge }\end{array}$ & - & $\begin{array}{l}\text { Examination of the association between airv } \\
\text { hyperresponsiveness to mannitol and the } \\
\text { inflammatory markers in the collected sputu } \\
\text { induced by hypertonic saline, blood and exh }\end{array}$ \\
\hline
\end{tabular}

Table 3: Clinical trials on eosinophils acting in oth ${ }^{.}$" $\epsilon_{\sim}$ piratory diseases

\begin{tabular}{|c|c|c|c|c|}
\hline $\begin{array}{l}\text { S. } \\
\text { No }\end{array}$ & Intervention & Condition & $\begin{array}{c}\text { No. of } \\
\text { recruitt le its } \\
\text { /Courtry,: n } \\
\text { a se } 6 \\
\text { s.'dy/Ongoi } \\
\text { ng/cancelled }\end{array}$ & Area of trial \\
\hline 1 & RPC4046 & $\begin{array}{l}\text { Eosinophilic } \\
\text { esophagitis }\end{array}$ & $\begin{array}{l}\text { i } 0 / \text { Multiple } \\
\text { ı untries/Pha } \\
\text { se } \\
\text { II/Completed }\end{array}$ & $\begin{array}{l}\text { Evaluation of RPC } 4046 \text { in eosinophilic esophagitis } p \\
\text { terms of efficacy and safety }\end{array}$ \\
\hline 2 & Albendazole & $\begin{array}{l}\text { Helmint } \\
\text { infertion }\end{array}$ & - & $\begin{array}{l}\text { Effect of infection by helminths on the status of activ } \\
\text { granulocytes. }\end{array}$ \\
\hline 3 & $\begin{array}{l}\text { Fractionated } \\
\text { exhaled } \\
\text { nitric oxide } \\
\text { (FeNO) } \\
\text { testing }\end{array}$ & $\begin{array}{l}\text { Er viropilitic } \\
\text { es } \text { vb gitis }\end{array}$ & $\begin{array}{l}\text { 120/United } \\
\text { States/NA/O } \\
\text { ngoing }\end{array}$ & $\begin{array}{l}\text { Utility of FeNO in predicting severity of eosinophilic } \\
\text { activity. }\end{array}$ \\
\hline 4 & Obesity & $\begin{array}{l}\text { Sinonasal } \\
\text { disease in } \\
\text { asthma }\end{array}$ & - & $\begin{array}{l}\text { Determination of the association between obesity anc } \\
\text { severity of sinonasal disease, and/or effects on treatm } \\
\text { nasal corticosteroid response in patients with asthma }\end{array}$ \\
\hline 5 & $\begin{array}{l}\text { Mepolizuma } \\
\text { b }\end{array}$ & $\begin{array}{l}\text { Eosinophilic } \\
\text { granulomatosi } \\
\text { S with } \\
\text { Polyangiitis }\end{array}$ & $\begin{array}{l}\text { 136/Multiple } \\
\text { countries/Pha } \\
\text { se } \\
\text { III/Complete } \\
\text { d }\end{array}$ & $\begin{array}{l}\text { Comparison between mepolizumab and a placebo as } \\
\text { regimen in relapse or refractory eosinophilic granulo } \\
\text { patients with polyangiitis in terms of its efficacy and } \\
\text { a duration of } 52 \text { weeks. }\end{array}$ \\
\hline 6 & $\begin{array}{l}\text { Mepolizuma } \\
\text { b }\end{array}$ & Nasal polyps & $\begin{array}{l}\text { 160/United } \\
\text { states \& } \\
\text { Europe/Phase }\end{array}$ & $\begin{array}{l}\text { Assessment between mepolizumab and a placebo in } \\
\text { safety and efficacy for treatment of severe bilateral } n \\
\text { polyposis. }\end{array}$ \\
\hline
\end{tabular}




\begin{tabular}{|c|c|c|c|c|}
\hline & & & III/Ongoing & \\
\hline 7 & Aspirin & $\begin{array}{l}\text { Aspirin- } \\
\text { exacerbated } \\
\text { respiratory } \\
\text { disease }\end{array}$ & - & $\begin{array}{l}\text { Investigation of the relationship between aspirin ther } \\
\text { associated clinical outcomes and levels of plasma eic } \\
\text { aspirin-exacerbated respiratory disease. }\end{array}$ \\
\hline 8 & Aspirin & $\begin{array}{l}\text { Aspirin- } \\
\text { exacerbated } \\
\text { respiratory } \\
\text { disease }\end{array}$ & - & $\begin{array}{l}\text { Determination of change ILC2 levles in peripheral bl } \\
\text { nasal mucosa in aspirin-exacerbated respiratory disea } \\
\text { COX-1 inhibitor-induced reactions. }\end{array}$ \\
\hline 9 & - & $\begin{array}{l}\text { Aspirin- } \\
\text { Exacerbated } \\
\text { Respiratory } \\
\text { Disease }\end{array}$ & - & Identification of the mechanistic basis for mast cell a \\
\hline 10 & Prednisolone & $\begin{array}{l}\text { Chronis } \\
\text { eosinophilic } \\
\text { pneumonia }\end{array}$ & $\begin{array}{l}\text { 50/Japan/Pha } \\
\text { se } \\
\text { IV/completed }\end{array}$ & $\begin{array}{l}\text { Compa son between short-term and long-term cortic } \\
\text { treatm in chronic eosinophilic pneumonia patients } \\
\text { its sa ty and effectiveness. }\end{array}$ \\
\hline 11 & Aspirin & $\begin{array}{l}\text { Aspirin- } \\
\text { exacerbated } \\
\text { respiratory } \\
\text { disease }\end{array}$ & - & $\begin{array}{l}\text { In resi gation of aspirin's capacity to trigger activatio } \\
\text { 'ost..uphils and mast cells in aspirin exacerbated rest } \\
\text { ts a ase. }\end{array}$ \\
\hline 12 & Aspirin & $\begin{array}{l}\text { Aspirin- } \\
\text { exacerbated } \\
\text { respiratory } \\
\text { disease }\end{array}$ & & $\begin{array}{l}\text { 1. vestigation of mechanism associated with the activ } \\
\text { eosinophils. } \\
\text { Identification of novel inflammatory mediators throu } \\
\text { utilization of proteomics. }\end{array}$ \\
\hline 13 & Reslizumab & $\begin{array}{l}\text { Eosinophilic } \\
\text { esophagitis }\end{array}$ & $\begin{array}{l}\text { Liך United } \\
\text { States \& } \\
\text { C’nada/Phas } \\
\text { II/Completed }\end{array}$ & $\begin{array}{l}\text { Evaluate the effectiveness of reslizumab in children } \\
\text { adolescent eosinophilic esophagitis subjects. }\end{array}$ \\
\hline 14 & $\begin{array}{l}\text { Budesonide/ } \\
\text { Montelukast } \\
\text { Double-dose } \\
\text { budesonide }\end{array}$ & $\begin{array}{l}\text { Non- } \\
\text { asthmatic } \\
\text { eosinoph 'ic } \\
\text { br... hius }\end{array}$ & $\begin{array}{l}\text { 63/China/Pha } \\
\text { se } \\
\text { IV/Unknown }\end{array}$ & $\begin{array}{l}\text { Comparison of effectiveness and tolerance between } r \\
\text { as an add-on therapy to budesonide and double dose } \\
\text { budesonide for the suppression of airway eosinophili } \\
\text { reduction of severity of cough in non-asthmatic eosir } \\
\text { bronchitis. }\end{array}$ \\
\hline 15 & Allergen & $\begin{array}{l}\text { Ai 'ergic } \\
\text { linnitis }\end{array}$ & - & $\begin{array}{l}\text { Determination of eosinophilia in the mucosa, apopto } \\
\text { eosinophils, general cell apoptosis, cell proliferation } \\
\text { and CCL11 expression in allergic airway tissues of } h \\
\text { resolution of symptomatic eosinophilic inflammation }\end{array}$ \\
\hline 16 & Montelukast & Bronchiolitis & $\begin{array}{l}\text { 146/Iran/NA/ } \\
\text { Completed }\end{array}$ & $\begin{array}{l}\text { Investigation of montelukast's effect on degranulatio } \\
\text { eosinophils and recurrent episodes of wheezing in pa } \\
\text { post-respiratory syncytial virus bronchiolitis. }\end{array}$ \\
\hline
\end{tabular}


Table 4: Current drugs acting on eosinophils in respiratory diseases

\begin{tabular}{|c|c|c|c|c|c|c|c|}
\hline $\begin{array}{l}\text { S. } \\
\text { N } \\
\text { o. }\end{array}$ & Drug & $\begin{array}{c}\text { Route of } \\
\text { administr } \\
\text { ation }\end{array}$ & $\begin{array}{c}\text { Indicati } \\
\text { on }\end{array}$ & $\begin{array}{c}\text { Mechanis } \\
\text { m of } \\
\text { action }\end{array}$ & $\begin{array}{l}\text { Biologica } \\
\text { l effee }^{+} \text {; }\end{array}$ & $\begin{array}{c}\text { Clinical } \\
\text { outcomes }\end{array}$ & $\begin{array}{c}\text { Referenc } \\
\text { e(s) }\end{array}$ \\
\hline 1. & $\begin{array}{l}\text { Reslizum } \\
\mathrm{ab}\end{array}$ & S & $\begin{array}{l}\text { Adjuncti } \\
\text { ve } \\
\text { treatmen } \\
\mathrm{t} \text { in } \\
\text { severe } \\
\text { eosinoph } \\
\text { ilic } \\
\text { asthma }\end{array}$ & $\begin{array}{l}\text { Humanized } \\
\text { anti-IL-5 } \\
\text { monoclonal } \\
\text { antibody }\end{array}$ & $\begin{array}{l}\text { B nds } \\
\text { al } 1 \\
\text { trates } \\
\text { to IL- } \\
5 \\
\text { which } \\
\text { inhibit } \\
\text { s } \\
\text { recept } \\
\text { or } \\
\text { bindin } \\
\text { g on } \\
\text { eosino } \\
\text { phil } \\
\text { surfac } \\
\text { e } \\
\text { Decre } \\
\text { ases } \\
\text { surviv } \\
\text { al and } \\
\text { activit } \\
\text { y of } \\
\text { eosino } \\
\text { phils }\end{array}$ & $\begin{array}{ll}\text { - } & 50 \% \\
\text { reductio } \\
\mathrm{n} \text { in } \\
\text { asthma } \\
\text { exacerb } \\
\text { ation } \\
\text { rates } \\
\text { - Improve } \\
\text { ment in } \\
\text { lung } \\
\text { function } \\
\text {, asthma } \\
\text { control } \\
\text { and } \\
\text { QOL }\end{array}$ & $\begin{array}{l}(89- \\
91,317)\end{array}$ \\
\hline 2. & $\begin{array}{l}\text { Mepolizu } \\
\text { mab }\end{array}$ & $\begin{array}{l}\text { SC } \\
\text { injection }\end{array}$ & $\begin{array}{l}\text { Adjuncti } \\
\text { ve } \\
\text { treatmen } \\
\mathrm{t} \text { in } \\
\text { refractor } \\
\mathrm{y} \\
\text { eosinoph } \\
\text { ilic } \\
\text { asthma } \\
\text { and }\end{array}$ & $\begin{array}{l}\text { Humanized } \\
\text { anti-IL-5 } \\
\text { monoclonal } \\
\text { antibody }\end{array}$ & $\begin{array}{l}\text { - } \begin{array}{l}\text { Binds } \\
\text { and }\end{array} \\
\text { seques } \\
\text { trates } \\
\text { to IL- } \\
5 \\
\text { which } \\
\text { inhibit } \\
\text { s } \\
\text { recept }\end{array}$ & $\begin{array}{ll}\text { - } & \text { Reducti } \\
\text { on in } \\
\text { blood } \\
\text { and } \\
\text { sputum } \\
\text { eosinop } \\
\text { hil } \\
\text { counts } \\
\text { - } \\
\text { Reducti } \\
\text { on in }\end{array}$ & $\begin{array}{l}(55,92- \\
94,317,31 \\
8)\end{array}$ \\
\hline
\end{tabular}




\begin{tabular}{|c|c|c|c|c|c|c|c|}
\hline & & & $\begin{array}{l}\text { severe } \\
\text { eosinoph } \\
\text { ilic } \\
\text { COPD }\end{array}$ & & $\begin{array}{l}\text { or } \\
\text { bindin } \\
\text { g on } \\
\text { eosino } \\
\text { phil } \\
\text { surfac } \\
\text { e } \\
\text { - Decre } \\
\text { ases } \\
\text { surviv } \\
\text { al and } \\
\text { activit } \\
\text { y of } \\
\text { eos ' o } \\
\text { pr.s } \\
\text { A ten } \\
\text { ua'es } \\
\text { ' ste } \\
\text { mic } \\
\text { differe } \\
\text { ntiatio } \\
\text { n of } \\
\text { eosino } \\
\text { phils }\end{array}$ & $\begin{array}{l}\text { asthma } \\
\text { exacerb } \\
\text { ation } \\
\text { rates } \\
\text { - Improve } \\
\text { ment in } \\
\text { lung } \\
\text { function } \\
\text {, asthma } \\
\text { control } \\
\text { and } \\
\text { QOL } \\
\text { Steroid- } \\
\text { sparing } \\
\text { effect } \\
\text { Reducti } \\
\text { on in } \\
\text { annual } \\
\text { rates of } \\
\text { moderat } \\
\text { e or } \\
\text { severe } \\
\text { COPD } \\
\text { exacerb } \\
\text { ations } \\
\end{array}$ & \\
\hline 3. & $\begin{array}{l}\text { Benralizu } \\
\text { mab }\end{array}$ & $\begin{array}{l}\text { SC } \\
\text { injection }\end{array}$ & $\begin{array}{l}\text { Adjun ti } \\
\text { ve } \\
\text { treatr le } 1 \\
\text { t ir. } \\
\text { sev se } \\
\text { cisinoph } \\
\therefore \text {. } \\
\text { usthma }\end{array}$ & $\begin{array}{l}\text { Hunanized } \\
\text { afucosylate } \\
\mathrm{d} \text { anti-IL- } \\
5 \mathrm{R} \alpha \\
\text { monoclonal } \\
\text { antibody }\end{array}$ & $\begin{array}{l}\text { - } \text { Block } \\
\text { s IL-5 } \\
\text { intera } \\
\text { ction } \\
\text { with } \\
\text { its } \\
\text { recept } \\
\text { or on } \\
\text { eosino } \\
\text { phils } \\
\text { Inhibit } \\
\text { s } \\
\text { eosino } \\
\text { phil } \\
\text { differe } \\
\text { ntiatio } \\
\text { n and } \\
\text { matur } \\
\text { ation } \\
\text { in } \\
\text { bone } \\
\text { marro } \\
\text { w } \\
\text { Induc } \\
\text { es Ab- }\end{array}$ & $\begin{array}{ll}\text { - } & \text { Rapid } \\
\text { reductio } \\
\mathrm{n} \text { of } \\
\text { serum } \\
\text { and } \\
\text { tissue } \\
\text { eosinop } \\
\text { hils } \\
\text { - } 50 \% \\
\text { reductio } \\
\text { n in } \\
\text { asthma } \\
\text { exacerb } \\
\text { ation } \\
\text { rates } \\
\text { Favoura } \\
\text { ble } \\
\text { results } \\
\text { on lung } \\
\text { function } \\
\text {, ACQ } \\
\text { and } \\
\text { QOL } \\
\text { Steroid- } \\
\text { sparing }\end{array}$ & $(97,317)$ \\
\hline
\end{tabular}




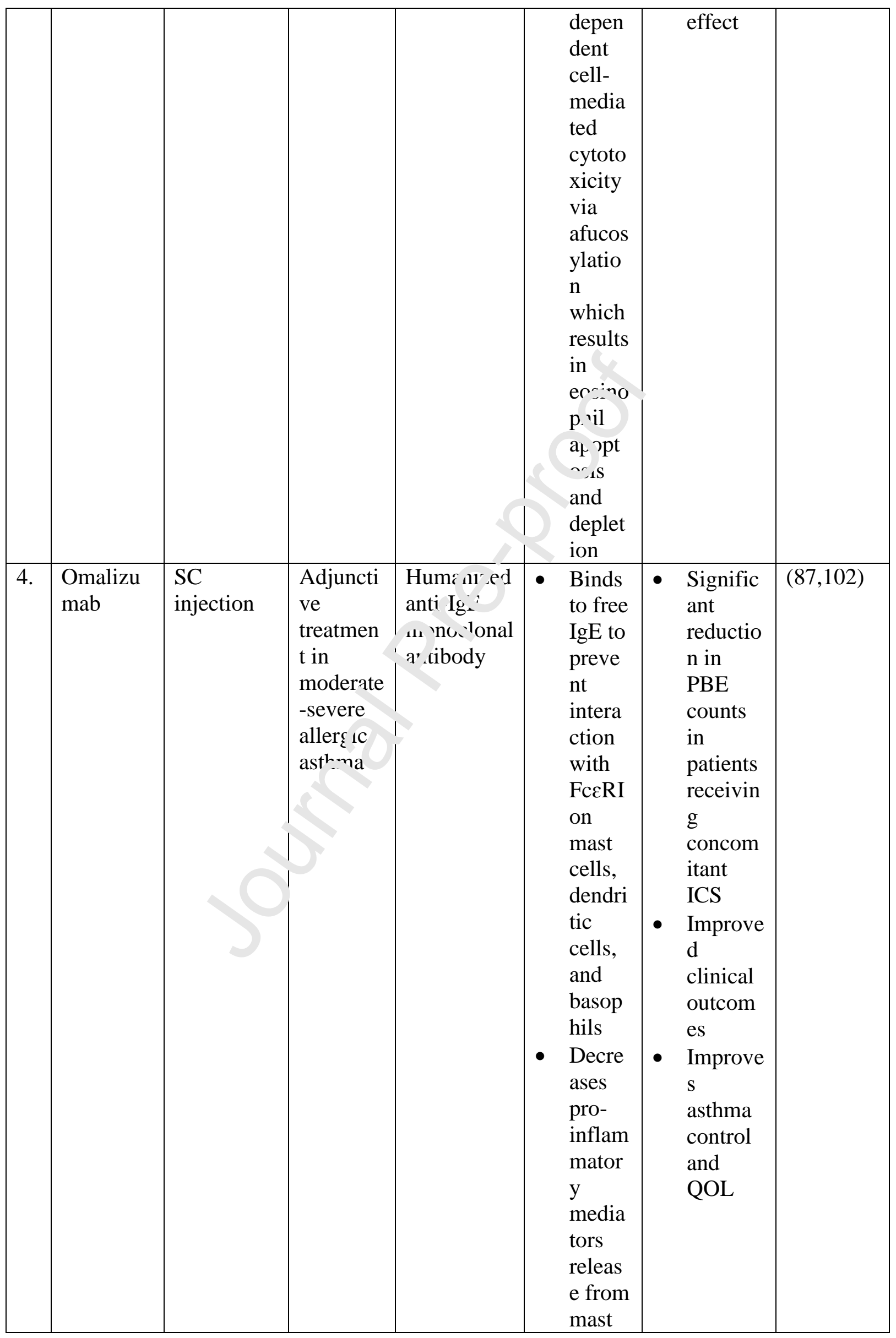




\begin{tabular}{|c|c|c|c|c|c|c|c|}
\hline & & & & & $\begin{array}{l}\text { cells } \\
\text { and } \\
\text { basop } \\
\text { hils } \\
\text { - } \text { Inhibit } \\
\text { s } \\
\text { allerg } \\
\text { en- } \\
\text { induce } \\
\text { d T- } \\
\text { cell } \\
\text { differe } \\
\text { ntiatio } \\
\text { n }\end{array}$ & & \\
\hline 5. & $\begin{array}{l}\text { Dupiluma } \\
\text { b }\end{array}$ & $\begin{array}{l}\text { SC } \\
\text { injection }\end{array}$ & $\begin{array}{l}\text { Adjuncti } \\
\text { ve } \\
\text { therapy } \\
\text { in severe } \\
\text { eosinoph } \\
\text { ilic } \\
\text { asthma }\end{array}$ & $\begin{array}{l}\text { Humanized } \\
\text { anti-IL- } \\
4 / \mathrm{IL}-13 \\
\text { monoclonal } \\
\text { antibody }\end{array}$ & $\begin{array}{l}\text { - B } \\
\text { tc IL- } \\
4 \mathrm{r} \alpha \\
\text { in } \\
\text { block } \\
\text { IL-4 } \\
\text { and } \\
\text { IL-13 } \\
\text { signali } \\
\text { ng } \\
\text { pathw } \\
\text { ay } \\
\text { Inhibit } \\
\text { s B- } \\
\text { cell } \\
\text { IgE } \\
\text { class } \\
\text { switch } \\
\text { ing } \\
\text { Reduc } \\
\text { es } \\
\text { airwa } \\
\text { y } \\
\text { recruit } \\
\text { ment } \\
\text { of } \\
\text { eosino } \\
\text { phils } \\
\end{array}$ & $\begin{array}{l}\text { Reducti } \\
\text { on in } \\
\text { asthma } \\
\text { exacerb } \\
\text { ation } \\
\text { rates } \\
\text { - Improve } \\
\text { ment in } \\
\text { AQLQ, } \\
\text { ACQ } \\
\text { and } \\
\text { FEV } \\
\text { Transie } \\
\text { nt } \\
\text { increase } \\
\text { in } \\
\text { peripher } \\
\text { al } \\
\text { eosinop } \\
\text { hil } \\
\text { counts } \\
\text { (especia } \\
\text { lly in } \\
\text { patients } \\
\text { with } \\
\text { baseline } \\
\text { blood } \\
\text { eosinop } \\
\text { hil } \\
\text { counts } \\
\text { of } \\
\geq 300 \\
\text { eosinop } \\
\text { hils/ } \mu \text { L) }\end{array}$ & $\begin{array}{l}(87,104,1 \\
10)\end{array}$ \\
\hline
\end{tabular}




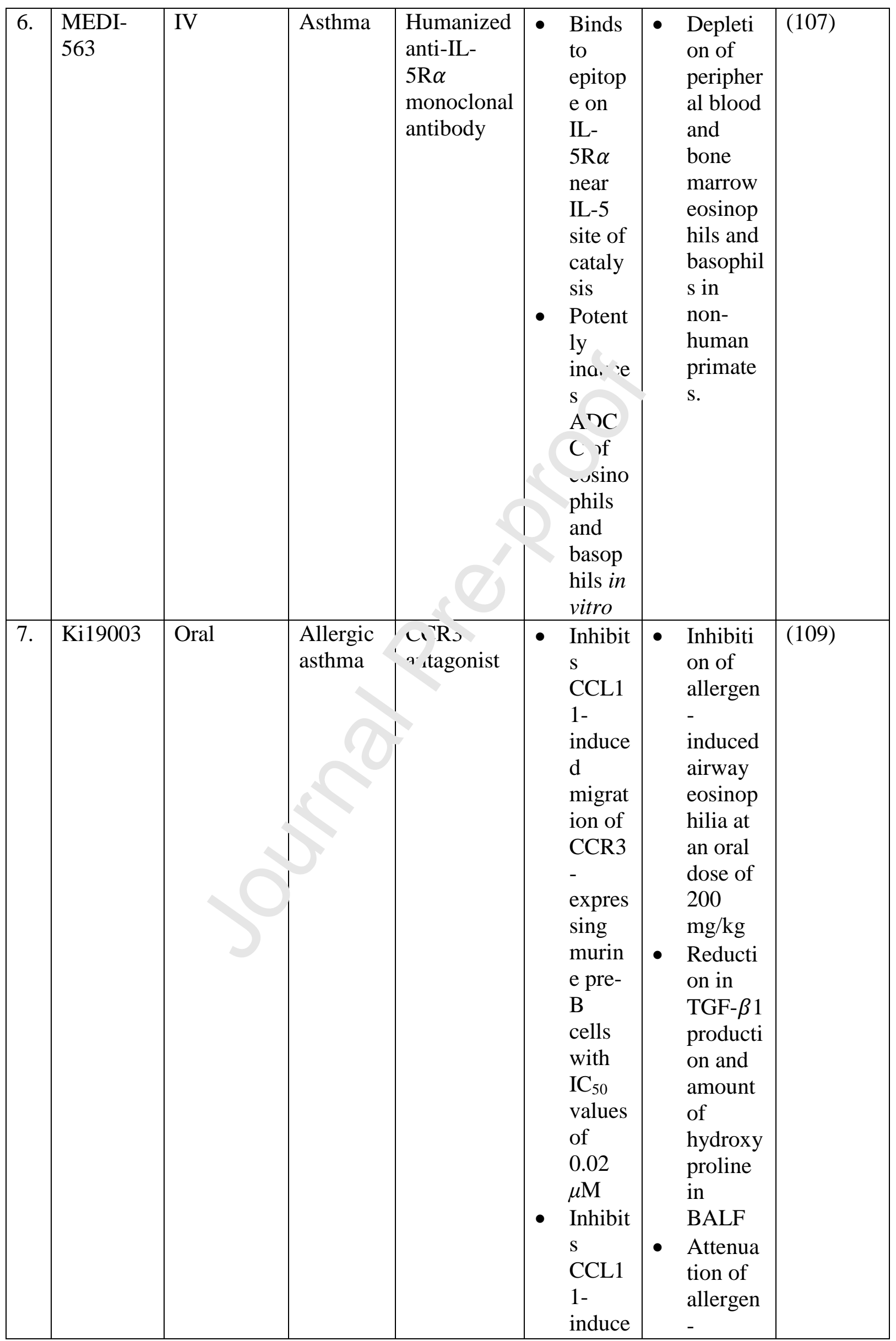




\begin{tabular}{|c|c|c|c|c|c|c|c|}
\hline & & & & & $\begin{array}{l}\mathrm{d} \\
\text { migrat } \\
\text { ion of } \\
\text { eosino } \\
\text { philic } \\
\text { granul } \\
\text { ocytes } \\
\text { from } \\
\text { bone } \\
\text { marro } \\
\text { W }\end{array}$ & $\begin{array}{l}\text { induced } \\
\text { subepith } \\
\text { elial and } \\
\text { peribron } \\
\text { chial } \\
\text { fibrosis }\end{array}$ & \\
\hline 8. & $\begin{array}{l}\text { Fevipipra } \\
\text { nt, } \\
\text { Timapipr } \\
\text { ant }\end{array}$ & Oral & $\begin{array}{l}\text { Fevipipr } \\
\text { ant: } \\
\text { Mild- } \\
\text { moderate } \\
\text { eosinoph } \\
\text { il- } \\
\text { dominan } \\
\text { t allergic } \\
\text { asthma } \\
\text { Timapipr } \\
\text { ant: } \\
\text { Persisten } \\
\text { t } \\
\text { eosinoph } \\
\text { ilic } \\
\text { asthn a }\end{array}$ & $\begin{array}{l}\text { Small } \\
\text { molecule } \\
\text { PGD2 } \\
\text { inhibitors }\end{array}$ & $\begin{array}{l}\text { - Antag } \\
\text { onist } \\
\text { of } \\
\text { CrTH } \\
2 \\
\text { ex res } \\
\text { zad on } \\
\text { eosino } \\
\text { phils } \\
\text { which } \\
\text { media } \\
\text { tes } \\
\text { chemo } \\
\text { tactic } \\
\text { respon } \\
\text { se to } \\
\text { PGD2 }\end{array}$ & $\begin{array}{l}\text { - } \text { Reducti } \\
\text { on in } \\
\text { sputum } \\
\text { eosinop } \\
\text { hil } \\
\text { counts } \\
\text { - Improve } \\
\text { ment of } \\
\text { asthmati } \\
\text { c } \\
\text { sympto } \\
\text { ms }\end{array}$ & $(110,111)$ \\
\hline 9. & $\begin{array}{l}\text { AMG } \\
157\end{array}$ & IV & $\begin{array}{l}\text { Mia } \\
\text { ali rgic } \\
\text { a.thma }\end{array}$ & $\begin{array}{l}\text { Humanized } \\
\text { anti-TSLP } \\
\text { monoclonal } \\
\text { antibody }\end{array}$ & 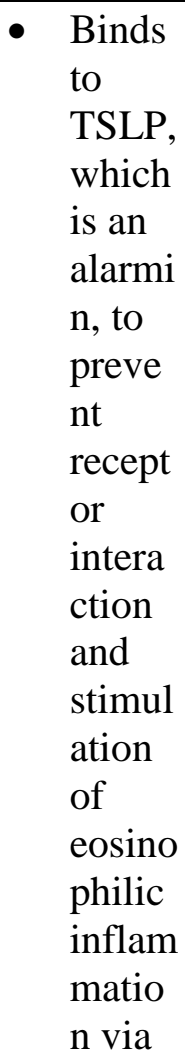 & $\begin{array}{l}\text { - Reducti } \\
\text { on in } \\
\text { maximu } \\
\mathrm{m} \\
\text { percenta } \\
\text { ge } \\
\text { decreas } \\
\text { e of } \\
\text { FEV } 1 \\
\text { - Reducti } \\
\text { on of } \\
\text { blood } \\
\text { and } \\
\text { sputum } \\
\text { eosinop } \\
\text { hil } \\
\text { counts } \\
\end{array}$ & (113) \\
\hline
\end{tabular}




\begin{tabular}{|c|c|c|c|c|c|c|c|}
\hline & & & & & $\begin{array}{l}\text { ILC2 } \\
\text { and } \\
\text { Th2 } \\
\text { pathw } \\
\text { ay }\end{array}$ & & \\
\hline 10 & $\begin{array}{l}\text { TPI } \\
\text { ASM8 }\end{array}$ & Inhalation & $\begin{array}{l}\text { Mild } \\
\text { allergic } \\
\text { asthma }\end{array}$ & $\begin{array}{l}\text { Antisense } \\
\text { oligonucleo } \\
\text { tides }\end{array}$ & $\begin{array}{ll}\text { Block } & \text { s } \\
\text { expres } \\
\text { sion } \\
\text { of } \\
\text { comm } \\
\text { on } \beta \mathrm{c} \\
\text { of IL- } \\
3 / \mathrm{h} \\
5 / \mathrm{G} \text { ' } \\
\text { - ' 'SF } \\
\text { re ept } \\
\text { is } \\
\text { Block } \\
\text { s } \\
\text { CCR3 } \\
\text { expres } \\
\text { sion }\end{array}$ & 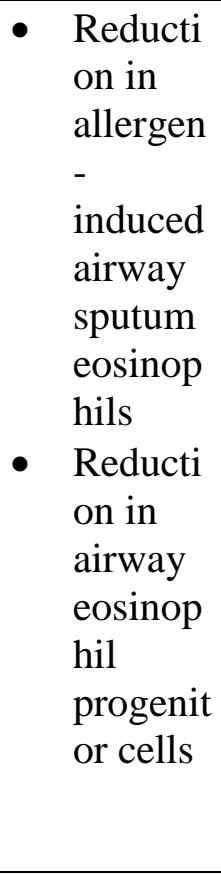 & (118) \\
\hline 11 & $\begin{array}{l}\text { Prednison } \\
\mathrm{e}\end{array}$ & Oral & $\begin{array}{l}\text { Severe } \\
\text { asthma }\end{array}$ & $\begin{array}{l}\text { A ti- } \\
\text { ry Jlammato } \\
\text { ry }\end{array}$ & 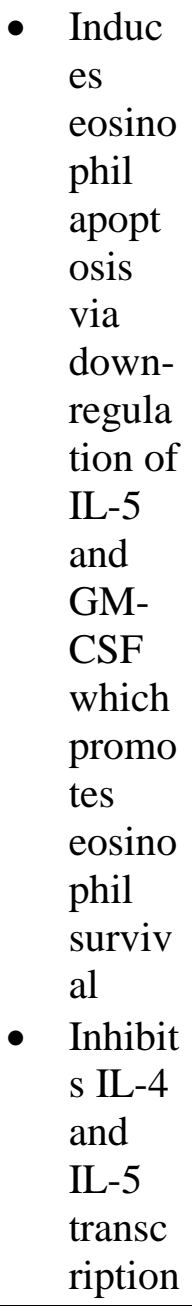 & $\begin{array}{l}\text { - Reducti } \\
\text { on of } \\
\text { eosinop } \\
\text { hilic/typ } \\
\text { e } 2 \\
\text { inflamm } \\
\text { ation } \\
\text { - Reducti } \\
\text { on in } \\
\text { sputum } \\
\text { eosinop } \\
\text { hil } \\
\text { counts } \\
\text { Reducti } \\
\text { on in } \\
\text { pro- } \\
\text { inflamm } \\
\text { atory } \\
\text { cytokin } \\
\text { e } \\
\text { concent } \\
\text { rations } \\
\text { Improve } \\
\text { ment in } \\
\text { pulmon } \\
\text { ary } \\
\text { function }\end{array}$ & $\begin{array}{l}(119,121, \\
122)\end{array}$ \\
\hline
\end{tabular}




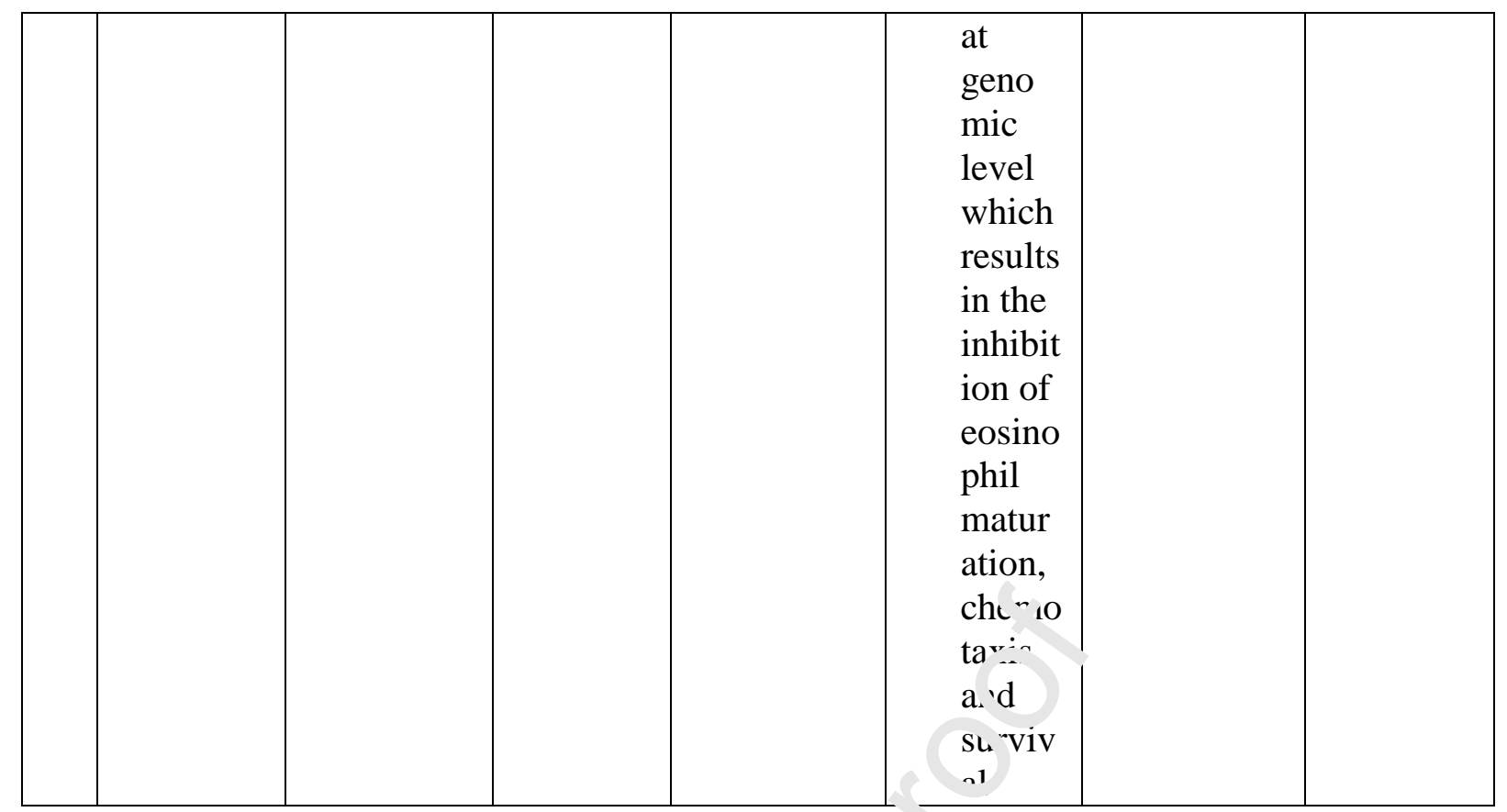

Abbreviations: IV (Intravenous); QOL (Quality of Lifa); SC (Subcutaneous); ACQ (Asthma Control Questionnaire); FceRI (High-affinity imm: nog obin E receptor); PBE (Peripheral blood eosinophil); ICS (Inhaled corticosteroids; ' 'QLQ (Asthma Quality of Life Questionnaire); $\mathrm{FEV}_{1}$ (Forced expiratory vol $\mathrm{Am}$ ); ADCC (Antibody-dependent cellular cytotoxicity); CCR3 (CC-chemokine receptc _... CCL (CC-chemokine ligand); TGF- $\beta 1$ (Transforming growth factor beta 1) $\sim^{\prime} A_{\llcorner}{ }^{5}$ (Bronchoalveolar lavage fluid); PGD2 (Prostaglandin D2); CRTH2 (Chemoat. ' ant receptor-homologous molecule expressed on Th2 cells); TSLP (Thymic stromal lymphop ietin); FeNO (Fraction of exhaled nitric oxide); ILC2 (Type 2 innate lymphoid cells); $\mu$ - (Beta chain); OCS (Oral corticosteroid); GM-CSF (Granulocyte-macrophage colony-st $\mathrm{m} u$ 'sting factor). 


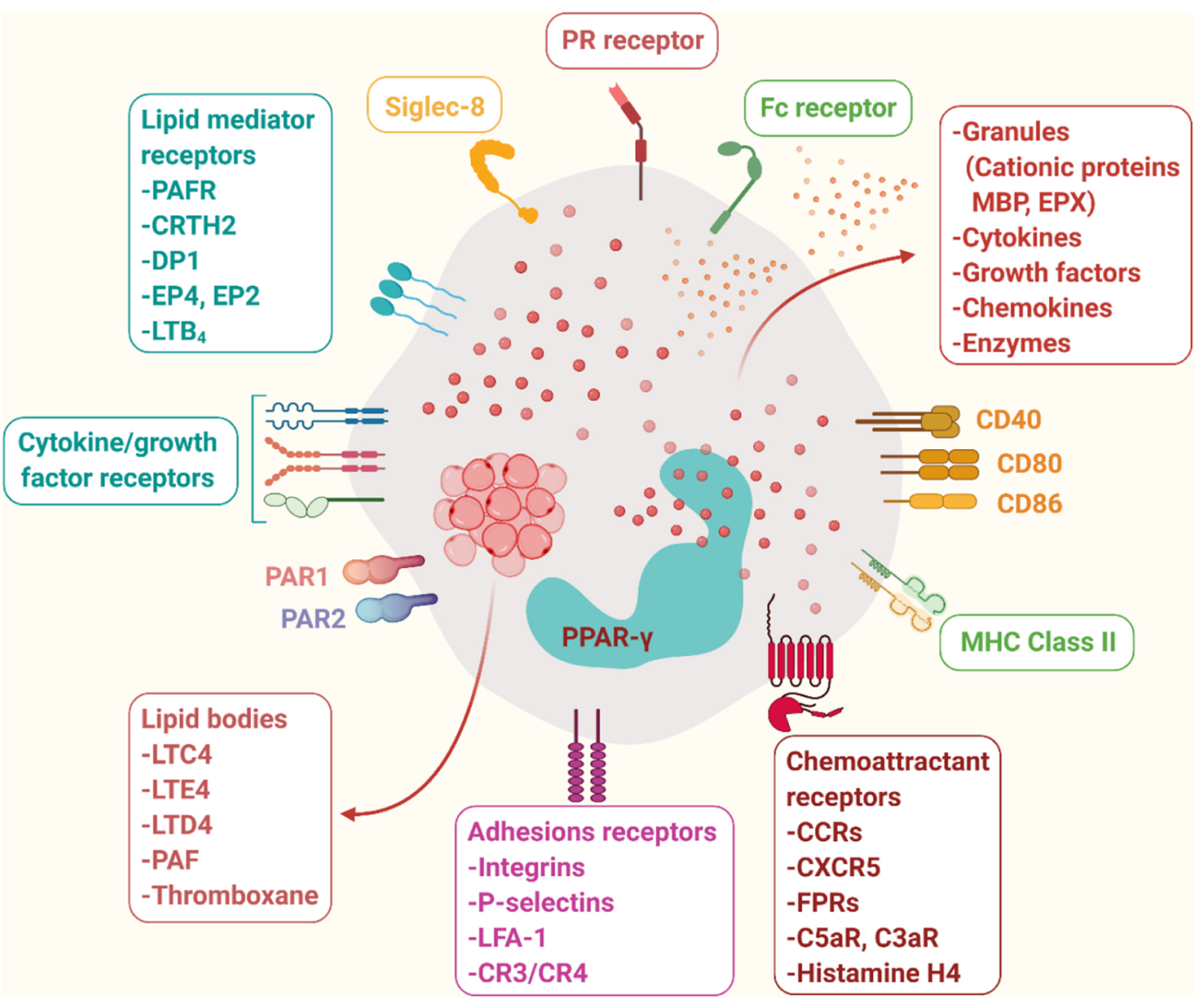

Figure 1 


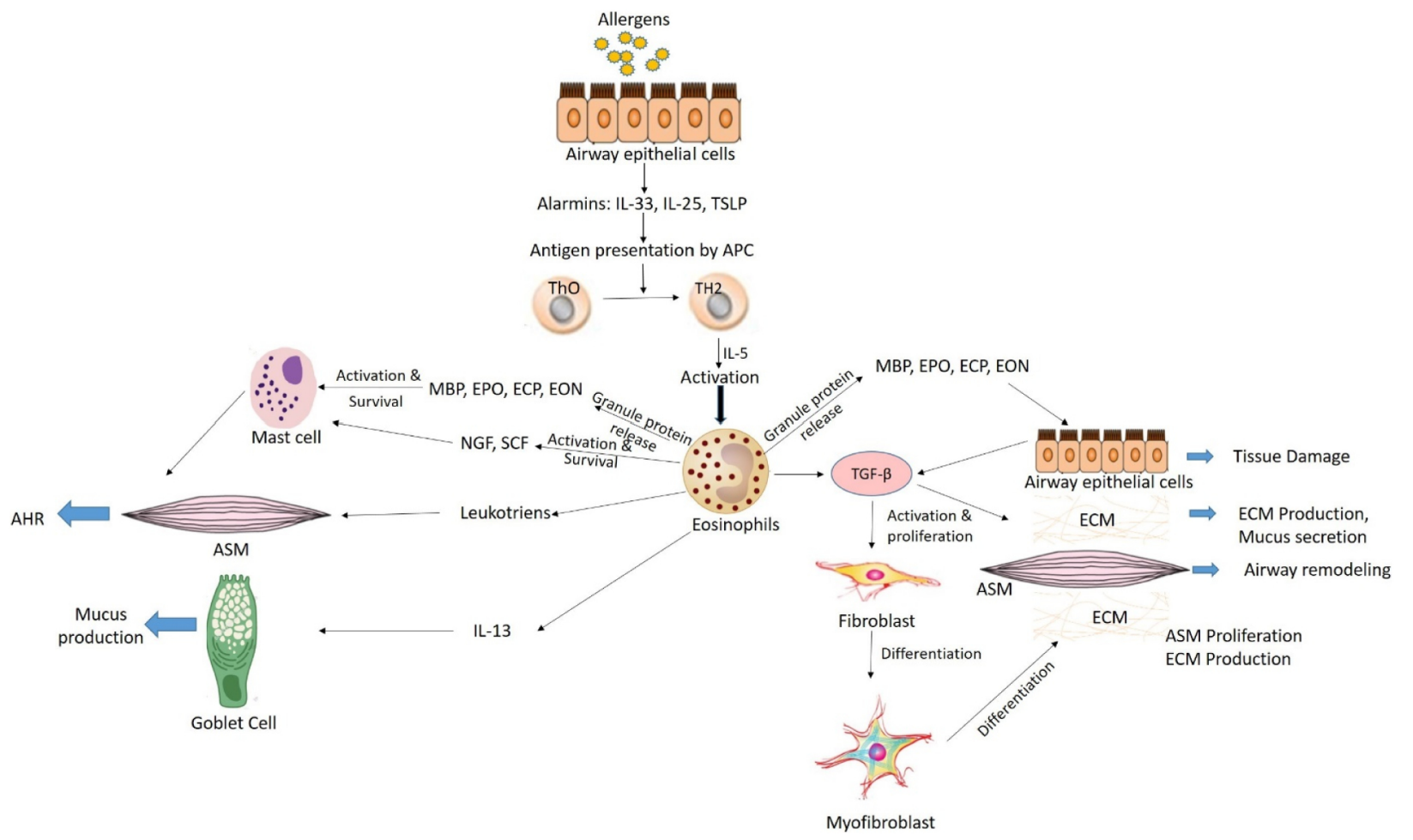

Figure 2 


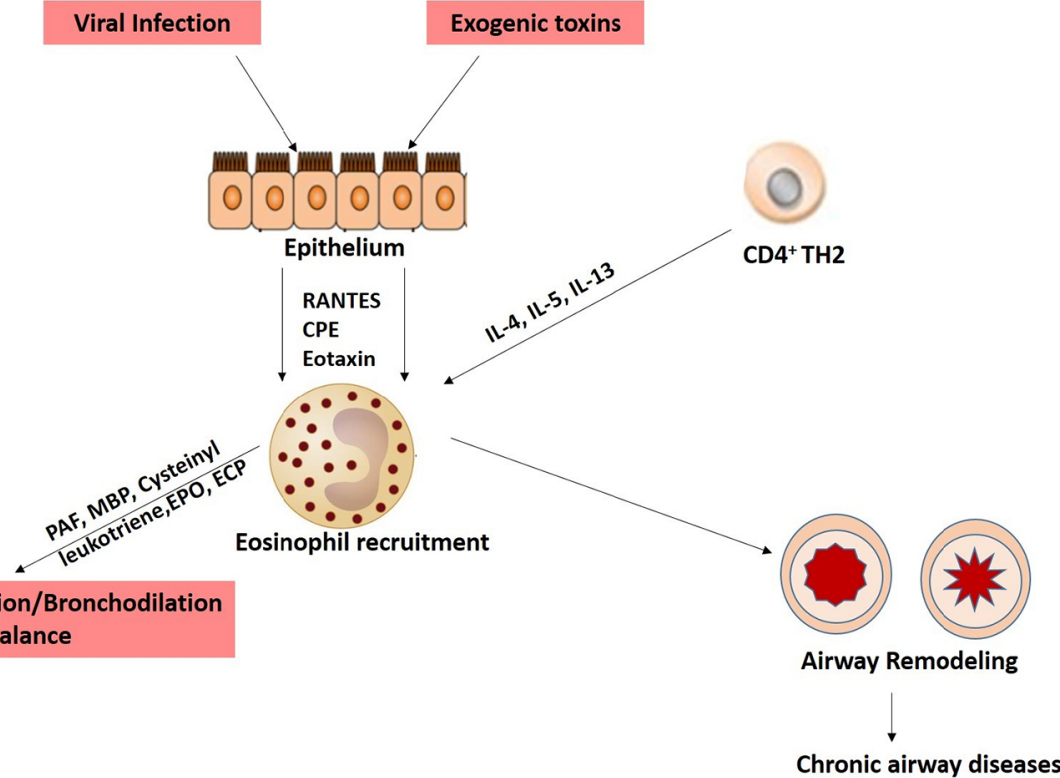

Figure 3 


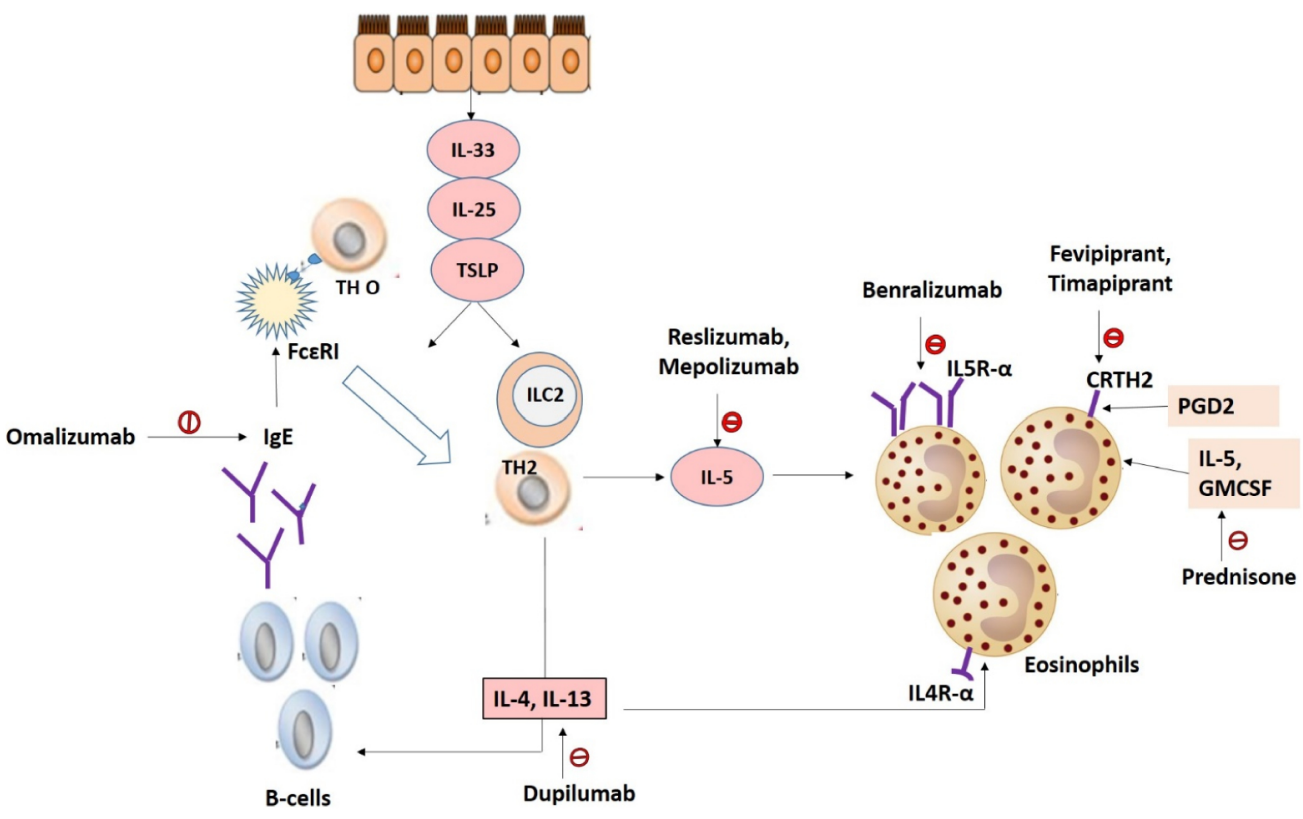

Figure 4 